\title{
Western Gas Sands Project Status Report
}

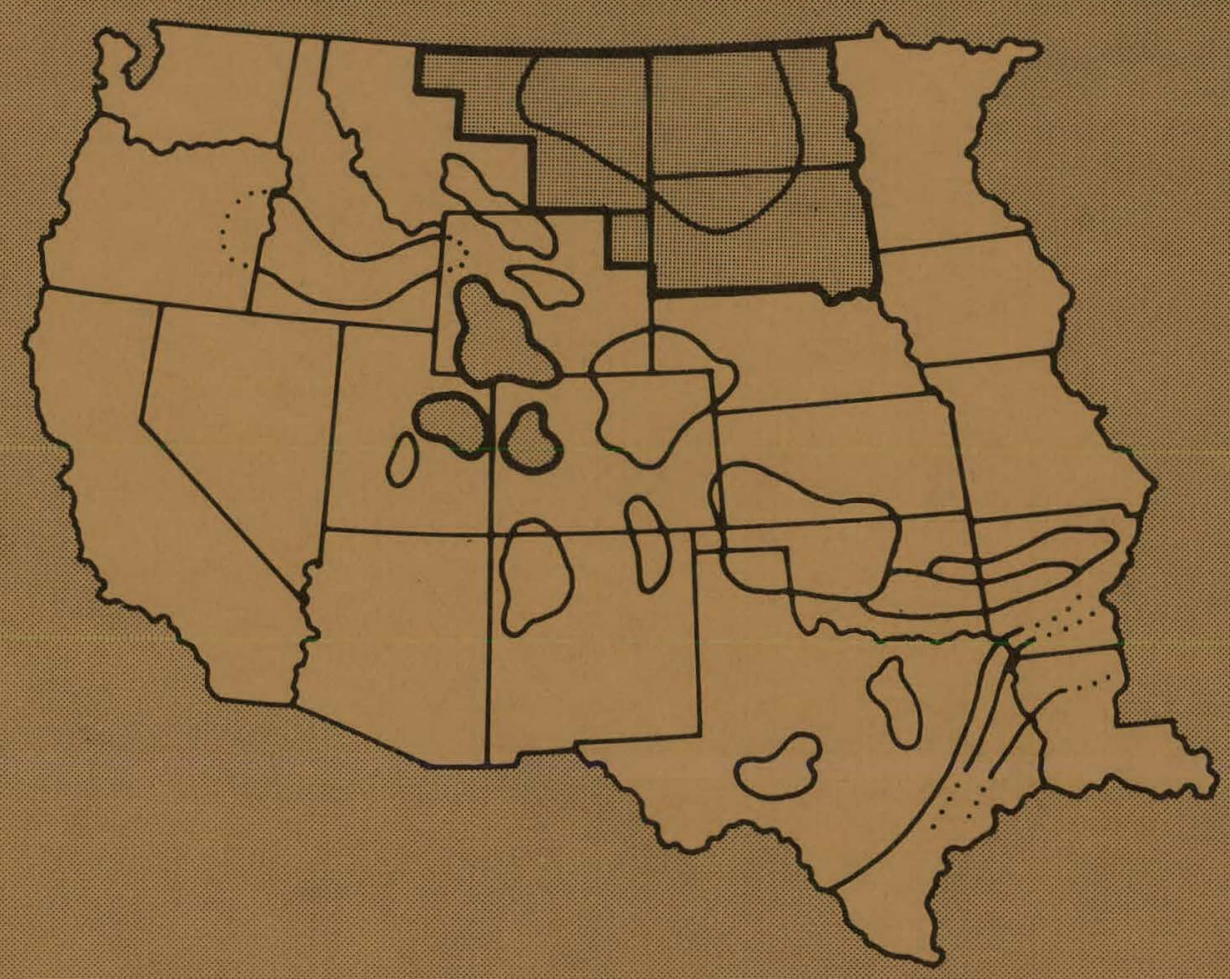

November 30, 1978

Prepared for

U.S. Department of Energy

Bartlesville Energy Technology Center

Charles H. Atkinson

Project Manager

Compiled by CER Corporation

Las Vegas, Nevada

Contract EY-76-C-08-0655 


\section{DISCLAIMER}

This report was prepared as an account of work sponsored by an agency of the United States Government. Neither the United States Government nor any agency Thereof, nor any of their employees, makes any warranty, express or implied, or assumes any legal liability or responsibility for the accuracy, completeness, or usefulness of any information, apparatus, product, or process disclosed, or represents that its use would not infringe privately owned rights. Reference herein to any specific commercial product, process, or service by trade name, trademark, manufacturer, or otherwise does not necessarily constitute or imply its endorsement, recommendation, or favoring by the United States Government or any agency thereof. The views and opinions of authors expressed herein do not necessarily state or reflect those of the United States Government or any agency thereof. 


\section{DISCLAIMER}

Portions of this document may be illegible in electronic image products. Images are produced from the best available original document. 
This report was prepared as an account of work sponsored by the United States Government. Neither the United States nor the United States DOE, nor any of their employees, nor any of their contractors, subcontractors, or their employees, makes any warranty, express or implied, or assumes any legal liability or responsibility for the accuracy, completeness, or usefulnes of any information, apparatus, product or process disclosed, or represents that its use would not infringe privately owned rights.

Available from the National Technical Information Service, U. S. Department of Commence, Springfield, Virginia 22161.

\section{NATIONAL TECHNICAL INFORMATION SERVICE PAPER COPY PRICES EFFECTIVE JANUARY 1,1976}

\begin{tabular}{|c|c|c|c|c|c|c|c|c|c|c|c|}
\hline $\begin{array}{l}\text { Page } \\
\text { range }\end{array}$ & $\begin{array}{c}\text { Domestic } \\
\text { price }\end{array}$ & $\begin{array}{l}\text { Page } \\
\text { range }\end{array}$ & $\begin{array}{c}\text { Domestic } \\
\text { price }\end{array}$ & $\begin{array}{l}\text { Page } \\
\text { range }\end{array}$ & $\begin{array}{l}\text { Domestic } \\
\text { price }\end{array}$ & $\begin{array}{l}\text { Page } \\
\text { range }\end{array}$ & $\begin{array}{c}\text { Domestic } \\
\text { price }\end{array}$ & $\begin{array}{l}\text { Page } \\
\text { range }\end{array}$ & $\begin{array}{c}\text { Domestic } \\
\text { price }\end{array}$ & $\begin{array}{l}\text { Page } \\
\text { range }\end{array}$ & $\begin{array}{c}\text { Domestic } \\
\text { price }\end{array}$ \\
\hline $001-025$ & $5 \$ 3.50$ & $126 \cdot 150$ & $\$ 6.00$ & $251-275$ & $\$ 9.00$ & $376-400$ & $\$ 10.75$ & $501 \cdot 525$ & $\$ 12.75$ & $701 \cdot 800$ & $\$ 1$ \\
\hline $026-050$ & $\$ 4.00$ & $151 \cdot 175$ & $\$ 6.75$ & $276-300$ & $\$ 9.25$ & $401-425$ & $\$ 11.00$ & $526-550$ & $\$ 13.00$ & $801-900$ & $\$ 21.25$ \\
\hline $051-075$ & $5 \$ 4.50$ & $176-200$ & $\$ 7.50$ & $301-325$ & $\$ 9.75$ & $426 \cdot 450$ & $\$ 11.75$ & $551-575$ & $\$ 13.50$ & $901-1000$ & $\$ 23.75$ \\
\hline $076 \cdot 100$ & $\$ 5.00$ & $201-225$ & $\$ 7.75$ & $326-350$ & $\$ 10.00$ & $451-475$ & $\$ 12.00$ & $576-600$ & $\$ 13.75$ & $1001-1100$ & $\$ 28.25$ \\
\hline $101 \cdot 125$ & $\$ 5.50$ & $226 \cdot 250$ & $\$ 8.00$ & $351-375$ & $\$ 10.50$ & $476 \cdot 500$ & $\$ 12.50$ & $601-700$ & $\$ 16.25$ & $1101-1200$ & $\$ 32.75$ \\
\hline
\end{tabular}

For additional pages, add $\$ 4.50$ for each beginning 100 pages. Add $\$ 2.50$ per copy for foreign price.

Microfiche $\$ 3.00$ (domestic) $\$ 4.50$ (foreign).

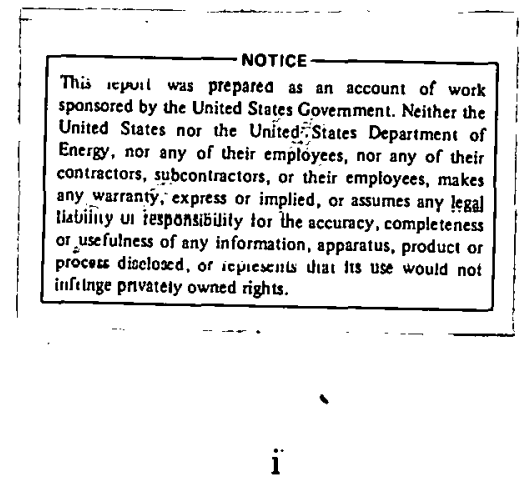




\section{CONTENTS}

Page

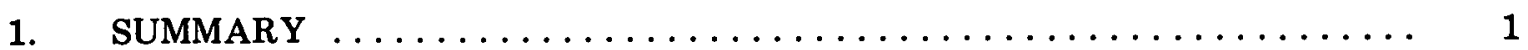

2. PROJECT MANAGEMENT $\ldots \ldots \ldots \ldots \ldots \ldots \ldots \ldots \ldots \ldots \ldots \ldots$

2.1 Technical Monitoring and Evaluation $\ldots \ldots \ldots \ldots \ldots \ldots \ldots \ldots$

2.2 Technology Transfer $\ldots \ldots \ldots \ldots \ldots \ldots \ldots \ldots \ldots \ldots \ldots \ldots$

3. RESOURCE ASSESSMENT $\ldots \ldots \ldots \ldots \ldots \ldots \ldots \ldots \ldots \ldots \ldots$

$3.1 \quad$ U.S. Geological Survey Activities $\ldots \ldots \ldots \ldots \ldots \ldots \ldots \ldots \ldots \ldots \ldots$

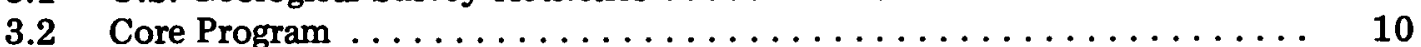

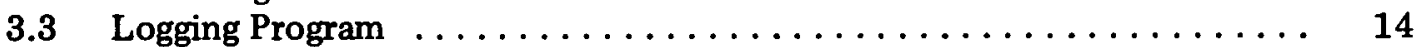

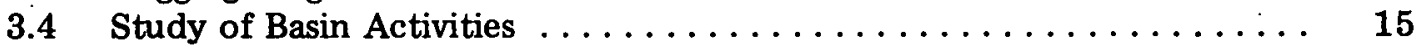

4. RESEARCH AND DEVELOPMENT BY ENERGY TECHNOLOGY CENTERS AND NATIONAL LABORATORIES $\ldots \ldots \ldots \ldots \ldots \ldots \ldots \ldots$

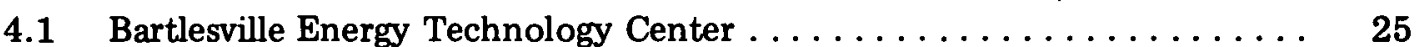

4.2 Lawrence Livermore Laboratory $\ldots \ldots \ldots \ldots \ldots \ldots \ldots \ldots \ldots \ldots . \ldots . \ldots 2$

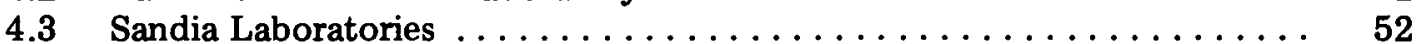

5. FIELD TESTS AND DEMONSTRATIONS $\ldots \ldots \ldots \ldots \ldots \ldots \ldots \ldots \ldots$

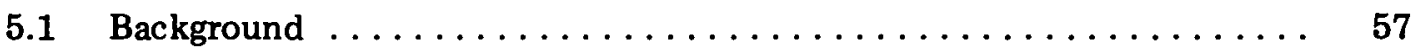

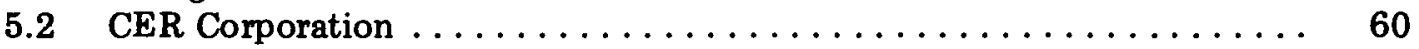

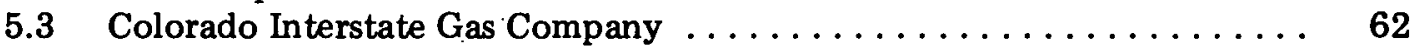

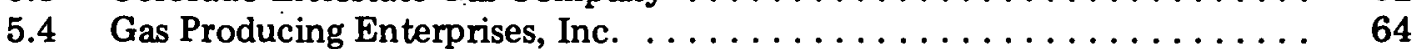

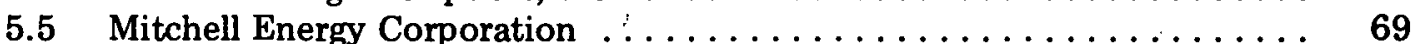

5.6 Mobil Research and Development Corporation . . . . . . . . . . . 80

5.7 Rio Blanco Natural Gas Company . . . . . . . . . . . . . . . . . . 84

5.8 Sandia Laboratories - Mineback $\ldots \ldots \ldots \ldots \ldots \ldots \ldots \ldots \ldots \ldots$ 


\section{FIGURES}

Page

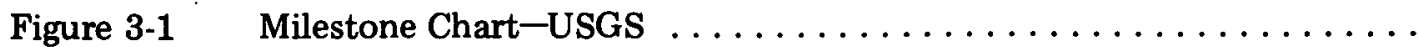

Figure 3-2 Greater Green River Basin Showing Wells of Interest and

USGS Designated Core Areas . . . . . . . . . . . 16

Figure 3-3 Northern Great Plains Province Showing Wells of Interest

and USGS Designated Core Areas A, B, C and D . . . . . . . 19

Figure 3-4 Piceance Basin Showing Wells of Interest and USGS

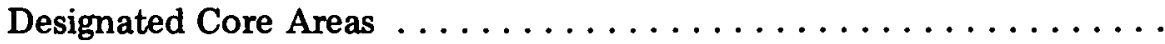

Figure 3-5 Uinta Basin Showing Wells of Interest and USGS Designated

Core Areas ............................ 23

Figure 4-1 Type Curve Plot for Mobil Well F31-13G, Zone 3 Build-Up . . . . . 28

Figure 4-2 Type Curve Plot for Mobil Well F31-13G, Zone 3 Build-Up

with Slopes Defined ....................... 29

Figure 4-3 $\Delta m(p)$ versus $\sqrt[4]{\Delta t}$ for Mobil Well F31-13G, Zone 3,

Pre-Frac Build-Up ....................... 31

Figure 4-4 Horner Plot of Mobil Well F31-13G, Pre-Frac, Build-Up . . . . . . 32

Figure 4-5 Type Curve Plot, Mobil Well F31-13G, Zone 3, Pre-Frac, Build-Up ... 34

Figure 4-6 Type Curve, Mobil Well F31-13G, Pre-Frac Build-Up,

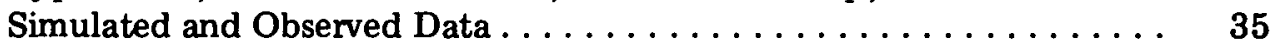

Figure 4-7 Horner Plot of Simulated Data for Zone 3 Pre-Frac, Build-Up

of Mobil F31-13G . . . . . . . . . . . . . . . . . 36

Figure $4-8 \quad$ Milestone Chart-BETC $\ldots \ldots \ldots \ldots \ldots \ldots \ldots \ldots \ldots \ldots$

Figure 4-9 Geometry of Problems with Cracks Approaching Bonded Interface Between Two Materials Having Moduli $\mathrm{E}_{1}$ and $\mathrm{E}_{2}, \nu_{2} \ldots \ldots, 42$

Figure 4-10 Axis of Maximum Principal Strain for the Case $E_{1}=10 \mathrm{GPa}$

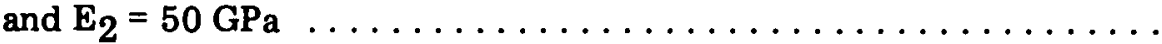


Figure 4-11 Axis of Maximum Principal Strain for the Case $\mathrm{E}_{1}=50 \mathrm{GPa}$

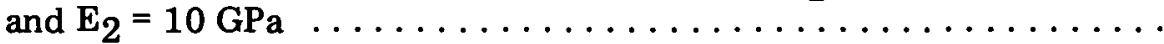

Figure 4-12 Normal Strain to Left of Interface as a Function of Distance Along the Interface for Various Distances of the Fracture Tip from the Interface $\ldots \ldots \ldots \ldots \ldots \ldots \ldots \ldots \ldots \ldots \ldots \ldots$

Figure 4-13 Shear Strain to Left of Interface for Various Distances of Fracture Tip from the Interface $\ldots \ldots \ldots \ldots \ldots \ldots \ldots \ldots$

Figure 4-14 Normal Strain to Right of Interface as a Function of Distance Along the Interface for Various Distances of Fracture Tip from the Interface

Figure 4-15 Shear Strain to the Right of Interface as a Function of Distance Along the Interface for Various Distances of Fracture Tip from

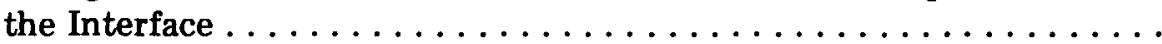

Figure 4-16 Normal Strain to Left of Interface as a Function of Distance Along the Interface for Various Distances of Fracture Tip from the Interface $\ldots \ldots \ldots \ldots \ldots \ldots \ldots \ldots \ldots \ldots \ldots \ldots \ldots \ldots$

Figure 4-17 Shear Strain to Left of Interface as a Function of Distance Along the Interface for various Distances of Fracture Tip from the Interface

Figure 4-18 Normal Strain to Right of Interface as a Function of Distance Along the Interface for Various Distances of Fracture Tip from the Interface . . . . . . . . . . . . . . . . . . . . .

Figure 4-19 Shear Strain to Right of Interface as a Function of Distance Along the Interface for Various Distances of Fracture Tip from the Interface $\ldots \ldots \ldots \ldots \ldots \ldots \ldots \ldots \ldots \ldots \ldots \ldots \ldots$

The Single Lens Geometry .

Figure 4-22 Geometry of Horizontally Arranged Triple Lenses . . . . . . . . .

Figure 4-23 Normal Stress in the y Direction Along the Lines BB or B' $\mathrm{B}^{\prime}$

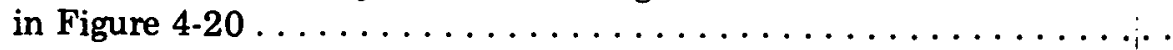


Figure 4-24 Normal Stress in the y Direction Along the Lines BB and B' $\mathrm{B}^{\prime}$

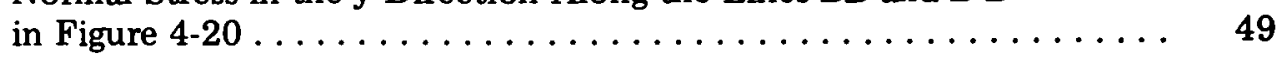

Figure 4-25 Normal Stress in the $\mathrm{x}$ Direction Along the Lines AA or $\mathrm{A}^{\prime} \mathrm{A}^{\prime}$

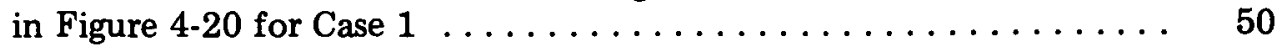

Figure 4-26 Normal Stress in the $x$ Direction Along the Lines AA or $A^{\prime} A^{\prime}$

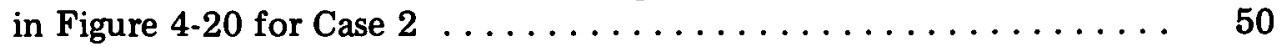

Figure 4-27 Normal Stress in the y Direction Along the Lines BB or $\mathrm{B}^{\prime} \mathrm{B}^{\prime}$ in Figure 4-21 for Case $1 \ldots \ldots \ldots \ldots \ldots \ldots \ldots \ldots \ldots \ldots$

Figure 4-28 Normal Stress in the y Direction Along the Lines BB or $\mathrm{B}^{\prime} \mathrm{B}^{\prime}$

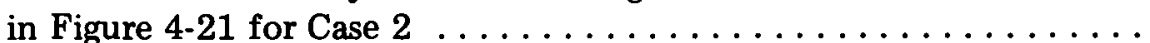

Figure 4-29 Normal Stress in the $x$ Direction for Lines AA or $A^{\prime} A^{\prime}$ in

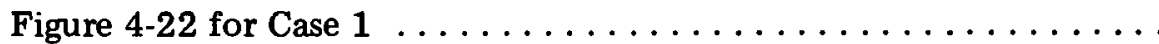

Figure 4-30 Normal Stress in the $x$ Direction for Lines $A A$ or $A^{\prime} A^{\prime}$ in

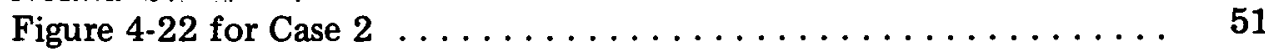

Figure $4-31 \quad$ Milestone Chart-LLL $\ldots \ldots \ldots \ldots \ldots \ldots \ldots \ldots \ldots \ldots \ldots$

Figure $4-32 \quad$ Milestone Chart-Sandia $\ldots \ldots \ldots \ldots \ldots \ldots \ldots \ldots \ldots \ldots \ldots$

Figure 5-1 Flow Rate Performance of Natural Buttes No. 9 Well $\ldots \ldots \ldots \ldots$

Figure 5-2 Flow Rate Performance of Natural Buttes No. 14 Well $\ldots \ldots \ldots \ldots$

Figure 5-3 Flow Rate Performance of Natural Buttes No. 18 Well $\ldots \ldots \ldots 6$

Figure 5-4 Flow Rate Performance of Natural Buttes No. 19 Well $\ldots \ldots \ldots \ldots 6$

Figure 5-5 Flow Rate Performance of Natural Buttes No. 20 Well $\ldots \ldots \ldots$. . 67

Figure 5-6 Flow Rate Performance of Natural Buttes No. 22 Well $\ldots \ldots \ldots \ldots$

Figure 5-7 Flowing Tubing Pressure and Rates of Initial Testing Period $\ldots \ldots \ldots 70$

Figure 5.8 Conventional Horner Plot for $16,350 \mathrm{lb}$ Gauge $\ldots \ldots \ldots \ldots \ldots$

Figure 5-9 . Conventional Horner Plot for $15,000 \mathrm{lb}$ Gauge $\ldots \ldots \ldots \ldots$

Figure 5-10 Bottomhole Tubing Pressure Difference Plot $\ldots \ldots \ldots \ldots \ldots$ 
Figure 5-11 Log-Log Plot of Pressure Changes versus Time After Shut in

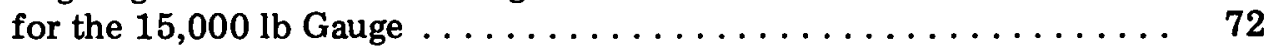

Figure 5-12 Conventional Plot for the Two-Rate Test $\ldots \ldots \ldots \ldots \ldots \ldots \ldots$

Figure 5-13 Flowing Bottomhole Tubing Pressure Difference Plot $\ldots \ldots \ldots \ldots$

Figure 5-14 Log-Log Plot of Pressure Changes for the Two-Rate Test . . . . . . 75

Figure 5-15 Change in Permeability During Damage and Clean Up . . . . . . 77

Figure 5-16 Trend of Permeability Fraction During Damage and Clean Up ...... 78

Figure 5-17 Fracturing Fluid Interaction Sample Assembly $\ldots \ldots \ldots \ldots \ldots$

Figure 5-18 Mobil F31-13G Well Showing Sands Fractured $\ldots \ldots \ldots \ldots \ldots$

Figure 5-19 Milestone Chart-Sandia (Mineback) $\ldots \ldots \ldots \ldots \ldots$ 


\section{TABLES}

Page

Table 3-1 . Summary of Wells of Interest - Greater Green River Basin . . . . . . 17

Table 3-2 Summary of Wells of Interest-Northern Great Plains Province . . . . . 20

Table 3-3 Summary of Wells of Interest-Piceance Basin $\ldots \ldots \ldots \ldots \ldots \ldots 22$

Table 3-4 Summary of Wells of Interest-Uinta Basin $\ldots \ldots \ldots \ldots \ldots \ldots$

Table $4-1 \quad$ Summary of Core Measurements $\ldots \ldots \ldots \ldots \ldots \ldots \ldots \ldots \ldots$

Table 4-2 Particle Size Distribution in Simulated Frac Fluid . . . . . . . . 37

Table 5-1 MHF Contract Locations and Frac Data $\ldots \ldots \ldots \ldots \ldots$

Table 5 -2 Reservoir Parameters $\ldots \ldots \ldots \ldots \ldots \ldots \ldots \ldots \ldots \ldots \ldots$

Table 5-3 Fracturing Fluid/Rock Interaction $\ldots \ldots \ldots \ldots \ldots \ldots \ldots \ldots$

Table 5-4 PCU No. 31-13G Completion Information $\ldots \ldots \ldots \ldots \ldots \ldots \ldots$ 


\section{SUMMARY}

This edition of the WGSP Status Report summarizes the progress during October, 1978 of government-sponsored projects directed toward increasing gas production from the lowpermeability gas sands of the western United States. Background information is provided in the September, 1977 Status Report, NVO/0655-100.

A Technology Implementation Plan (TIP) meeting was held at the CER office in Las Vegas, Nevada, October 16-19 to initiate the implementation phase of the Enhanced Gas Recovery (EGR) working group activities.

A WGSP Logging Program meeting was conducted on October 24, 1978 at CER offices to define the problems associated with logs in tight gas sands.

CER personnel and the project manager attended a two-day course on the fundamentals of core and reservoir analysis in Denver, Colorado, and met with USGS personnel to discuss USGS work on the WGSP.

A meeting was held to discuss a contract for coring a Twin Arrow well on the Douglas Creek Arch, Colorado.

CER Corporation personnel attended the Geological Society of America Annual Meeting held in Toronto, Canada, October 23-27 and a Gas Stimulation Workshop at Sandia Laboratories in Albuquerque, New Mexico, October 11 and 12 to discuss recent mineback experiments conducted at the Nevada Test Site.

Fiscal year 1979 projects initiated by USGS and the Energy Technology Centers and National Laboratories are progressing as scheduled.

The USGS has expanded the boundaries of the Northern Great Plains Province to include the entire states of North and Eouth Dakota.

Mobil Research and Development Corporation fractured zone 8 of the F-31-13G well in Rio Blanco County, Colorado. Colorado Interstate Gas Company poured the concrete pad for the compresser expected to be delivered in December and were laying pipeline between the wells at month end. The Mitchell Energy well, Muse Duke No. 1 was flowing on test at a rate of 2,100 MCFD and preparations proceeded to fracture the well on November 15 with approximately $1,000,000 \mathrm{gal}$ of fluid and 3,000,000 lb of sand. Terra Tek completed laboratory analyses of cores taken from the Mitchell Energy well. 


\section{THIS PAGE}

\section{WAS INTENTIONALLY \\ LEFT BLANK}




\section{PROJECT MANAGEMENT}

\subsection{TECHNICAL MONITORING AND EVALUATION}

Representatives of DOE, CER, Booz-Allen, Lewin \& Associates, TRW, CK GeoEnergy and Commercialization Insights met in Las Vegas October 16-19 to initiate the TIP phase of the EGR Working Group activities. A list of participants appears below.

Charles Atkinson
Alex Crawley
Robert Johansen
Conrad Appledorn
Gerald Luetkehans
Robert Mann
John Boyer
Frank Gentry
Walt Holman
Jerry Brashear
Lloyd Elkins
William Bailey
Carroll Knutson
Charles Ware

\author{
DOE - NV \\ DOE - HQ \\ DOE - BETC \\ CER Corporation \\ CER Corporation \\ CER Corporation \\ Booz-Allen \& Hamilton \\ Booz-Allen \& Hamilton \\ Booz-Allen \& Hamilton \\ Lewin \& Associates \\ Lewin \& Associates (consultant) \\ TRW \\ CK GeoEnergy \\ Commercialization Insights
}

Work included an expansion of the initial Strategic Plan and development of a comprehensive tactical plan for the technology development activities necessary to realize the goals of the projects delineated in the Strategic Plan-Volume I for the WGSP. The TIP will function as a monitoring tool for DOE - HQ and budget authorities to determine and evaluate progress. In addition, the TIP will be used by HQ as the primary management tool for the initiation of new projects, redirection of existing projects and the allocation of supplemental funds. Finalization of the TIP is scheduled in October, 1979.

The WGSP Log Program meeting was held at CER offices, October 24, 1978. The purpose of the meeting was to discuss the WGSP Logging Program Document, August 14, 1978, and to define the problems inherent with logs in tight gas sands.

The meeting is discussed in greater detail in Section 3.3, "Log Program" of this report.

D. C. Bleakly, H. E. Newman and L. T. Hodges, CER personnel, and C. H. Atkinson, attended a two-day course on core analysis in Denver, Colorado, October 30-31. The course revicwed physical characteristics of reservoir rock, the makeup and mechanics of the fluid content and flow, sampling and preservation procedures, laboratory measurements and equipment, the interpretation of core data, special rock properties and applications. 
Following the core analysis course, D. C. Bleakly, H. E. Newman, L. T. Hodges and G. C. Kukal met with Chuck Spencer, Ben Law, Ted Tyler and Louise Kitely to discuss ongoing and future USGS work.

D. C. Bleakly of CER met with Tom Fouch of USGS to discuss ongoing work in the Uinta Basin and the results from this summer's field studies dealing principally with outcrops.

H. E. Newman and G. C. Kukal met with Dudley Rice to review log analysis problems in the Northern Great Plains Province and the recent expansion of the Province to include all of North and South Dakota. (See Section 3.4.2, "Basin Activities - Northern Great Plains Province" for details concerning the expansion.)

Mr. Kukal met with several people while at USGS and brief summaries of each meeting follow:

- C. W. Spencer and G. C. Kukal met to review the USGS input into the WGSP Logging Program. Individual points related to the Logging Program Document were considered as well as USGS log analysis tasks.

- Mr. Ching Wu's paper, Density Neutron Crossplot Analysis for Shaly Gas Sands Using Hand Carried Calculators, (the abstract of this paper appears in Section 2.2.2 "Articles and Publications" of this report) was reviewed and discussed. Mr. Kukal and Ching Wu also discussed Scientific Software Corporation's (SSC) LOGCALC system, recently purchased by USGS for use in the WGSP. The system will be available for limited use by CER personnel and the upcoming SSC course "Use of Digitized Well Logs" to be attended by G. C. Kukal, will serve as a guide for how CER can best take advantage of the SSC software package.

- A meeting with Dan Gautier of USGS focused on petrographic analysis of the Eagle sandstone in the Northern Great Plains Province.

Chuck Spencer, director of the USGS effort, conducted a tour of the facilities in use in the tight gas program and introduced people involved with the varied aspects of the project to CER. The tour included lineament studies, petrographic analysis, SEM studies (including mini-SEM), X-ray diffraction and fluroescence studies, and thin-section lab techniques. Also explained was the handling of the USGS core library.

C. H. Atkinson, H. E. Newman and D. C. Bleakly met with Gordon Byers of Twin Arrow and Craig Rightmeyer of TRW to discuss coring a Twin Arrow well on the Douglas Creek Arch. No problems were encountered, although more work was required before a contract could be drafted.

L. T. Hodges attended the Geological Society of America Annual Meeting held this year in Toronto, Canada from October 23-27. A paper on the paleoenvironments of the Green River Formation in Wyoming, and several papers on Cretaceous shales and sediments were presented. A number of papers on exploration for oil and gas, and a special symposium on exploration using satellites (LANDSAT) were also presented. 
R. L. Mann, CER Corporation, attended a Sandia Laboratories hosted Gas Stimulation Workshop on October 11 and 12, 1978 in Albuquerque, NM. The objective was to allow detailed examination and discussion of the results from recent mineback experiments conducted at the Nevada Test Site. Details of this meeting are presented in Section 5.8.2 "Sandia Laboratories-Mineback, Current Status" of this report.

\subsection{TECHNOLOGY TRANSFER}

\subsubsection{Documentation and Reports}

Data compilation continued for the fourth Quarterly Basin Activities Report, to include information for the months of July, August and September. The Status Report, August 31,1978 has been distributed and Status Report, September 30,1978 has been completed and will be released shortly. Financial supplement reports for the end of fiscal year 1978 and October, 1978 have been completed. Both reports will be released shortly. An initial draft of an operations manual has been prepared to assist in the set up and operation of the DOE Well Test Facility. The compiling of material for the WGSP Bibliography continued.

\subsubsection{Articles and Publications}

As a result of the USGS/CER Corporation meetings in Denver, Colorado, and routine literature search, the following papers were made available to the WGSP file. Abstracts, when available, are included.

Density - Neutron Crossplot Analysis for Shaly Gas Sands Using Hand-Carried Calculators Ching H. Wu, U.S. Geological Survey and Colorado School of Mines, and Jack Krug, Petro-Lewis Corporation

Abstract-A program for hand-carried calculators has been developed for shaly gas sand crossplot analysis. This program processes data obtained from a log suite consisting of FDC-CNL-GR and a deep-investigation resistivity log, and prints out values for effective porosity, shale content, and water saturation.

The program uses an analytical method that describes the shaly-sand crossplot technique. This technique is capable of handling cases where the density porosity at the clay point is either positive or negative. The program executes the crossplot analysis accurately and quickly, taking less than 30 seconds for each data point.

Formation Evaluation and Gas Detection in Shallow, Low-Permeability Shaly Sands of the Northern Great Plains Province.

Gerald C. Kukal, CER Corporation

to be presented at the SPE Symposium on Low-Permeability Gas Reservoirs, May 20.22, 1979, nenver, Colorado 
Abstract-Montana log, core, and production data are combined with geology in a systematic approach for improved log analysis of shallow Upper Cretaceous gas sands having a high silt-clay content. Qualitative (overlay) techniques are reviewed with emphasis placed upon the normalized $\Delta t-$ compensated neutron overlay for gas detection. Various log crossplots and log-core crossplots are utilized in the analysis of lithology, formation factor, effective porosity, and permeability.

Several conventional water saturation models are discussed and compared for quantitative saturation analysis. The Total Shale Relation is recommended as the best method for saturation evaluation. Log parameters relating to this equation are generalized and refined.

Suggestions are made for improved log quality of porosity logs and for supplementing present $\log$ evaluations by using unconventional logging programs.

Core Descriptions, Photographs and Core X-ray Analysis of Portions of the Upper Cretaceous Mesaverde Group, Washakie Basin, Wyoming Theodore F. Tyler, USGS, Open File Report 78-708, 1978

Abstract-Eleven cores from the Upper Cretaceous Mesaverde Group in the Washakie Basin, Wyoming were described, photographed, and sampled at the U.S. Geological Survey core library, Denver, Colorado. Core-analysis data and bulk-sample X-ray data are included to supplement the core descriptions.

\author{
Influence of Diagenetic Reactions on Reservoir Properties of the Neslen, \\ Farrer, and Tuscher Formations, Uinta Basin, Utah \\ C. W. Keighin, USGS, under preparation for presentation in \\ Denver, Colorado, 1979 SPE Symposium
}

\title{
Mineralogical Analysis of Drill Core Samples From Midlands Gas Corporation Wells - Federal 0370 No. 1 and 2962 No. 1 Phillips County, Montana \\ Dudley Rice, USGS
}

Abstract-This report records the mineralogy of core samples from two wells in Phillips County, Montana. These wells are located in the Bowdoin gas field in north-central Montana. The gas is produced from low-permeability reservoirs at shallow depths (less than $610 \mathrm{~m}$ ) over an area of $1554 \mathrm{~km}$.

\section{Fracturing Fluid Rock Interaction of Cotton Valley Lime Formation U. Ahmed, L. Buchholdt, A. S. Abou-Sayed, Terra Tek}

Abstract-Laboratory analyses were performed on cores taken from Mitchell Energy Corporation's Muse-Duke Well No. 1, Limestone County, Texas, to 
determine fracturing fluid interaction with the host rock. All tests were conducted at simulated in situ conditions of 8,800 psi confining pressure, 6,400 psi pore pressure, 40 percent saturation and $285^{\circ} \mathrm{F}$. Three candidate fracturing fluids were evaluated: Versagel; Stratafrac 400; Polaris 60 . Tests were carried out to assess, (1) fracturing fluid damage to the rock permeability and (2) clean-up efforts required to return the host rock to its initial permeability. Irrespective of the initial, untreated permeability; post treatment permeability was in the tenths of microdarcies range. Initial permeability of the rock treated with Versagel and Stratafrac 400 was recovered in less than 2 hours. With Polaris 60 , post fracture permeability appeared to stabilize at 60 percent of the initial permeability.

Further fracturing fluid/rock interaction tests will be performed with the above mentioned fracturing fluids on core samples from the same well in addition to microscopic examination of the cores.

Transient Pressure Analysis for Fractured Wells

Heber Cinco-L, Stanford University, and

Fernando Samaniego-V., Instituto Mexicano del Petroleo, Members SPE-AIME, SPE 7490

Abstract-Several methods have been presented in the literature for analyzing transient pressure data of fractured wells. In this work, the limitations and advantages of each of these techniques are discussed. It is shown how different methods may be combined to accomplish a more reliable analysis.

In addition, a new analytical solution is presented for the unsteady-state flow behavior of wells intersecting a vertical fracture of low and intermediate conductivities at small values of time. A graphical technique is provided to analyze pressure data under these conditions. It is shown that a plot of $p_{w f}$ versus $\sqrt[4]{t}$ yields a straight line whose slope depends upon the group $h_{f} \sqrt{w k_{f}}$, where $h_{f}, w$, and $k$ are the height, width, and permeability of the fracture, respectively. The limitations of this method are discussed.

Detcction Within the Wollbore of Seismic Signals Created hy Hydraulic Fracturing Carl Schuster, Sandia Laboratories, SPE 7448, presented at the 53rd Annual SPE Technical Conference

Abstract-Early in 1978, Sandia Labs participated in massive hydraulic fracture mapping experiments with Amoco in the Wattenburg area. On two of these massive hydraulic fractures in the Sussex formation, a downhole, wall clamped, three-axis geophone was tested. On the first experiment, the system was clamped in the open hole section during the break-down phase. On the second experiment, the system was lonated in the luhricator during the main fracture and was lowered into place after shut-in.

Rreakdnwn pump for the first experiment was conducted in four phases. The formation was first broken down and shut-in for a quiet period and then three 5,000 gal stages of fluid, without proppant, were pumped with a quiet 
period after each. Following the last quiet period, flow back was started and half way through, a shut-in was scheduled for the fifth and last quiet period. During even the smallest flow rates, the noise induced into the geophones was extremely large and masked any other seismic activity. During the quiet periods, several seismic events were observed. These apparently are from two sources: 1) motion associated with permanent movements of the fracture face and 2) high frequency impulsive sources possibly associated with thermal fracturing.

Following the 124,000 gal fracture on the second experiment, the seismic system was lowered into place and clamped into the casing $50 \mathrm{ft}$ above the open hole section that had been fractured. Seismic signals were recorded for approximately six hours after shut-in when the test was terminated. Both types of signals seen on the early experiment also appear to be present after the fracture treatment.

\section{An Overview of the Electrical Potential Method for Determining Fracture Orientation \\ Carl L. Schuster, Sandia Laboratories, presented at the 1978 Annual ASCE Meeting}

\subsubsection{Project Data Bank}

Topographical maps of Wyoming are to be received from the USGS, Denver along with an east-west cross section of the Washakie Basin and an east-west cross section of the Green River Basin. Copies of several isolith and sand percentage maps for several Upper Cretaceous Formations are being sent to CER Corporation from USGS.

D. C. Bleakly visited the Utah State Oil and Gas Commission in Salt Lake City, Utah to arrange for photocopying production records. Monthly production figures were pulled for most months back through 1965. The monthly production figures are reported by lease and in several cases a lease will include a number of wells. The Oil and Gas Commission also maintains production records for each well, which can be photocopied if necessary. 


\section{RESOURCE ASSESSMENT}

Geological, geophysical and reservoir evaluation studies are necessary to define and characterize the resource base. The USGS is performing the majority of these studies with support provided by field test data and core acquisition and analysis.

\subsection{U. S. GEOLOGICAL SURVEY ACTIVITIES}

\subsubsection{Greater Green River Basin}

The Green River Basin proper outcrop and log cross sections are being reviewed prior to open-filing.

Tentative agreements were made with Champlin Oil and Gas to conduct a geochemical profile on a drilling well in the vicinity of Moxa Arch in western Green River Basin.

Ten samples from the Green River Basin were submitted for palynological examination.

X-ray diffraction analysis of samples taken from the Superior No. 1 Pacific Creek Unit well, Section 27, T27N, R103W, Sublette County, Wyoming were conducted.

Work continued on construction of a cross section network.

B. E. Law and Ching Wu attended the DOE meeting in Las Vegas on a proposed well logging program for core support wells.

\subsubsection{Northern Great Plains Province}

A talk was presented to the Rocky Mountain Association of Geologists on the natural gas potential of tight reservoirs in the Northern Great Plains Province.

Data on the Bowdoin Field in north-central Montana is being collected for a SPE paper.

Work is progressing on assessing reservoir properties of the Eagle Sandstone at the Tiger Ridge Field in the Bearpaw Mountains area. Gas is produced from conventional reservoirs in the coastal sandstone facies. These reservoirs will be compared with the low-permeability shelf sandstones to the east when core hernmes available.

USGS-Denver is working with the Water Resources Division of USGS on the possibility of examining cores through the Pierre Shale in central South Dakota. This will provide an opportunity to evaluate the potential of producing gas from a predominantly shale sequence that may be naturally fractured. 


\subsubsection{Uinta Basin}

A report is being prepared to discuss control of reservoir properties in Upper Cretaceous rocks at Southman Canyon gas field. The paper will be published in SPE volume if accepted.

\subsubsection{Piceance Basin}

A manuscript is being prepared to discuss stratigraphy as depicted on the cross sections which have previously been released or are in review prior to release. The units involved contain many of the natural gas bearing reservoirs in the Piceance Basin.

\subsubsection{Schedule Status}

Figure 3-1 is a milestone chart for USGS projects undertaken for FY 1979. Work is progressing as scheduled.

\subsection{CORE PROGRAM}

Twin Arrow Company has agreed to participate in the WGSP Core Program. Their well C\&K 4-14 is located in the Douglas Creek Arch area of Colorado, Section 14, T3S, R101W, in Rio Blanco County, Colorado. The location is approximately 10 miles southwest of the nearest designated core area, however after discussions with USGS personnel, it was decided that coring a portion of the continental Mesaverde section would be useful to the project. Close study of the shallow Mesaverde sands in this locale will give a clearer understanding of diagenetic changes that take place basinward with increasing depth of burial.

The interval chosen for coring in Twin Arrow's C\&K 4-14 well was based on close analysis of logs from nearby wells including:

$\begin{array}{ll}\text { Twin Arrow } & \text { C\&K 1-13, 1-13x } \\ \text { Conoco } & \text { Pollock Draw 1 } \\ \text { Utex Explor } & \text { Cathedral 1-A } \\ \text { Argo Oil } & \text { Government Gates 1 } \\ \text { Fuelco } & \text { Federal 23-1 } \\ \text { Twin Arrow } & \text { C\&K 1-12 East Douglas }\end{array}$

Sec 13, T3S, R101W
Sec 15, T3S, R101W
Sec 20, T3S, R100W
Sec 3, T3S, R101W
Sec 23, T3S, R101W
Sec 12, T3S, R101W

Several wells in the area have had gas shows throughout the proposed interval. Working with Density and E-log cross plots on the $1-13 x$ well, it was determined that three sands in the continental Mesaverde section had approximately a 50 percent gas saturation. These sands are the focus of the coring interest in Well C\&K 4-14, one-third mile west.

The core interval includes seven distinct sand zones varying from very clean with 20 percent plus porosity to very shaley with as little as 8 percent porosity. Thin shaley and coaly zones separate the sands. 


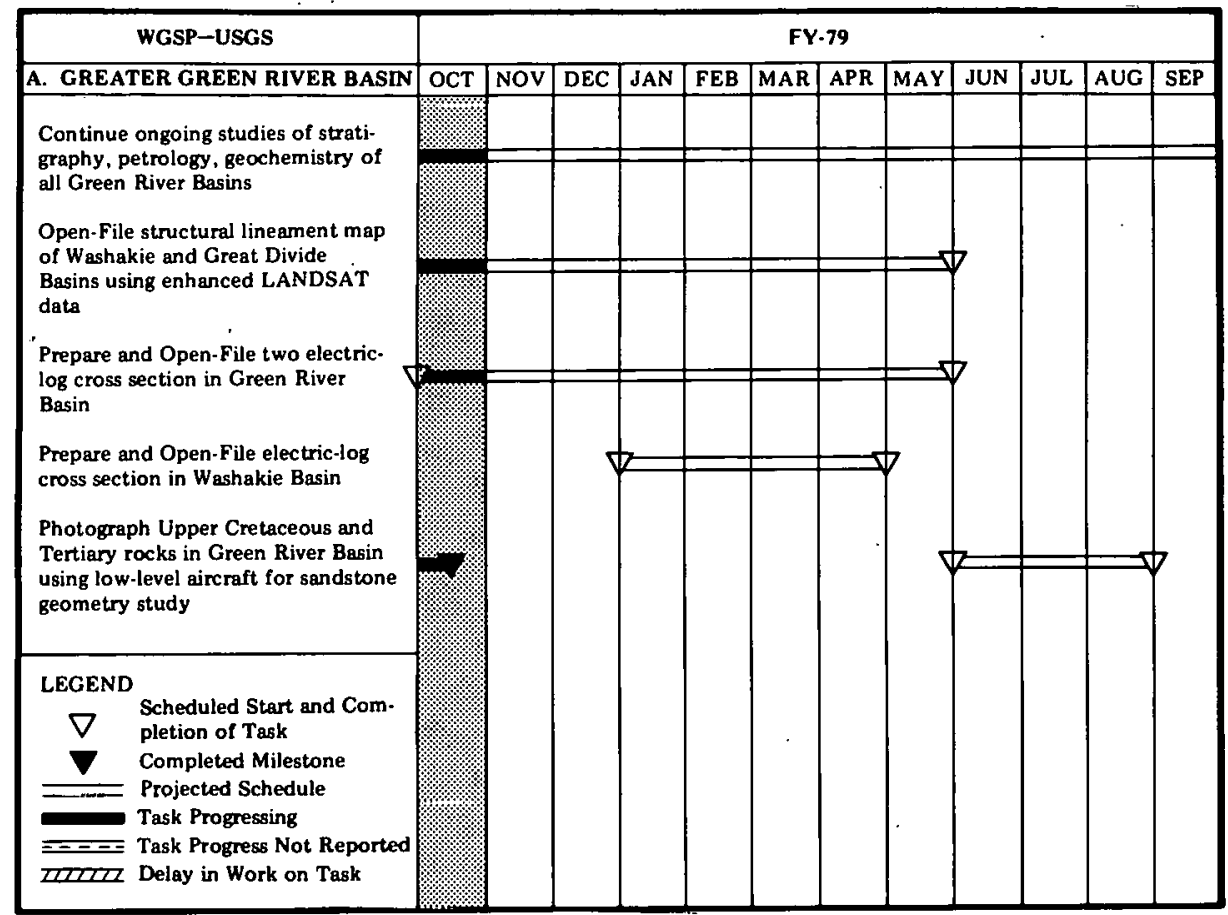

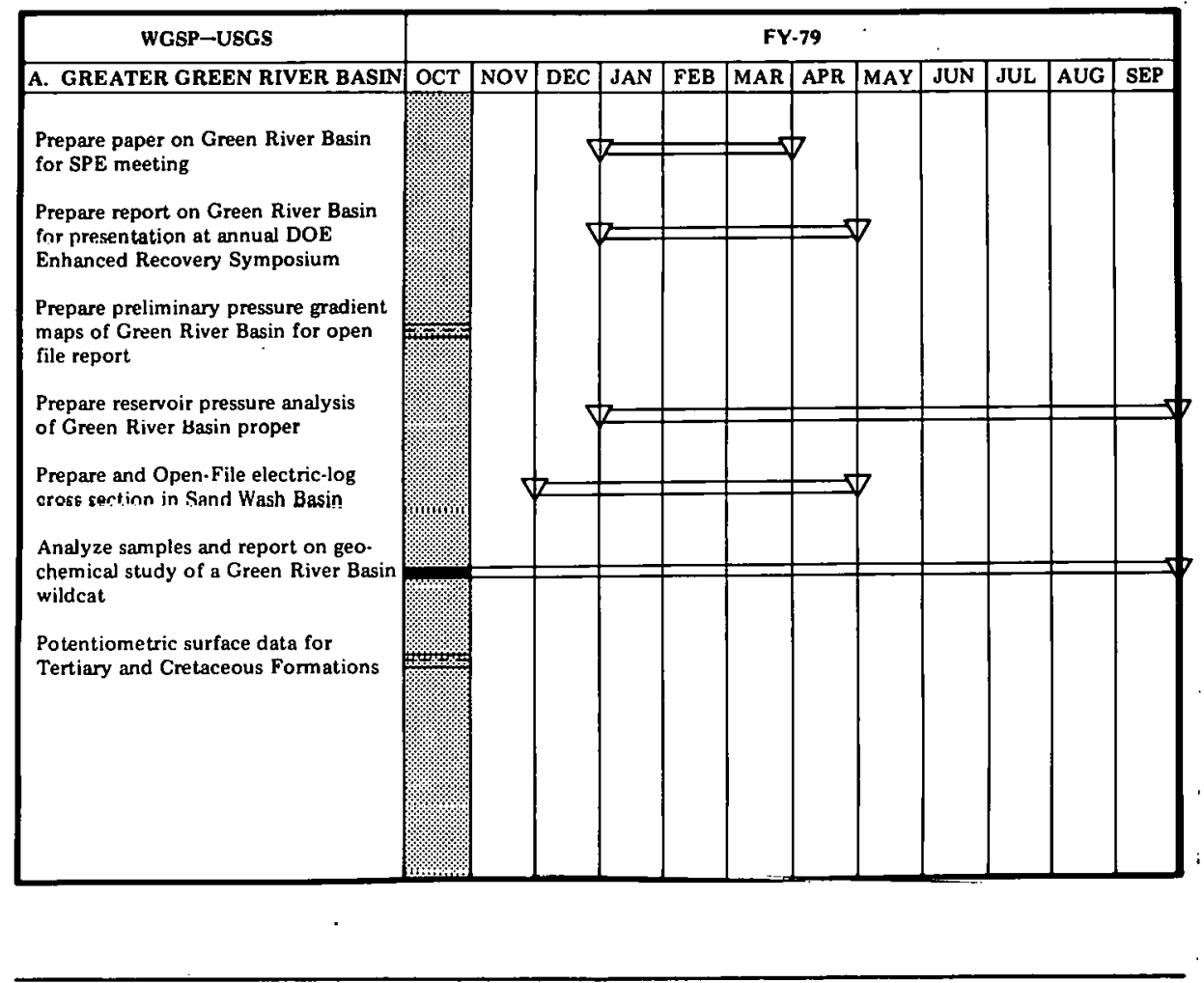

Figure 3-1 Milestone Chart-USGS 

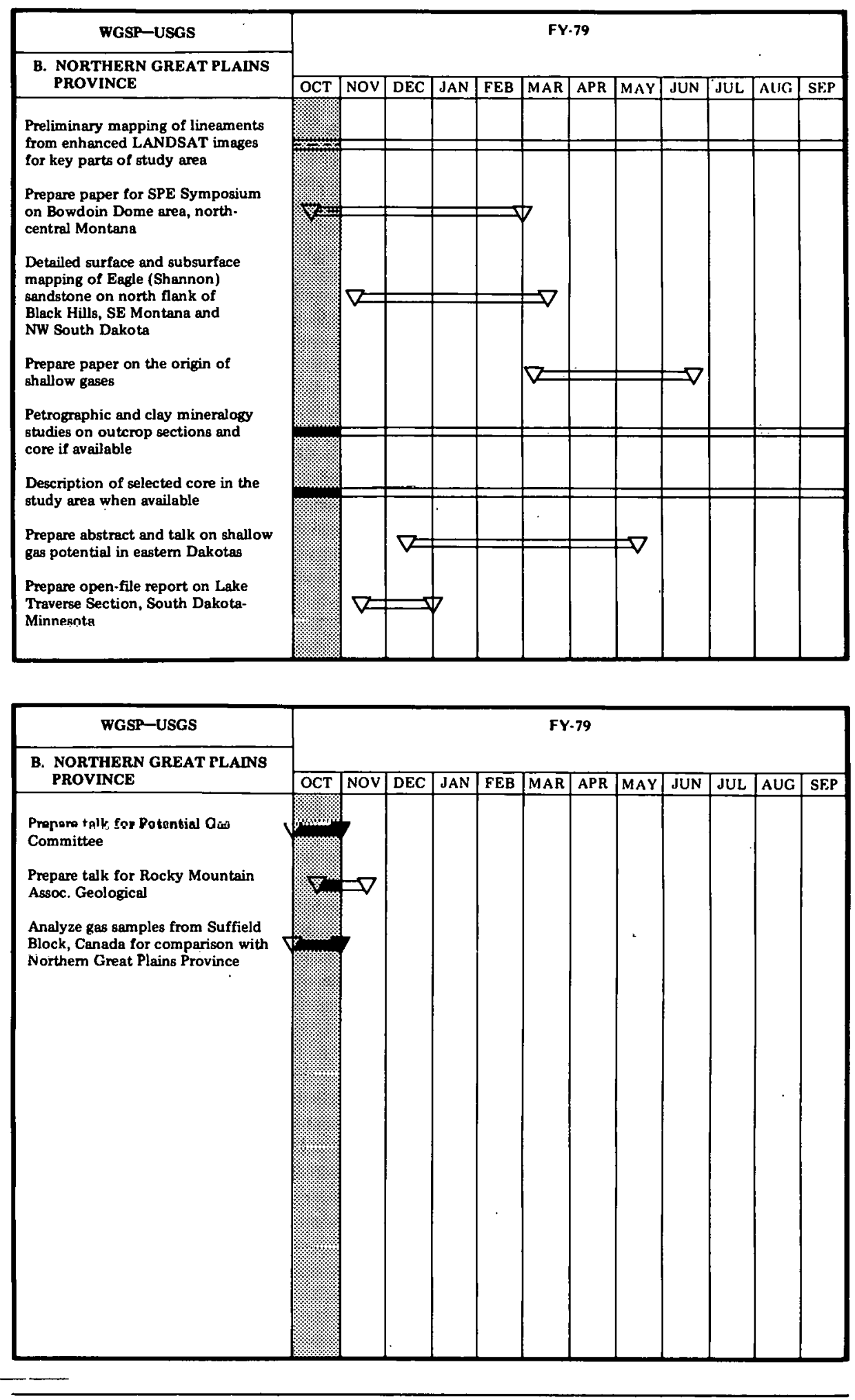

Figure 3-1 Continued 


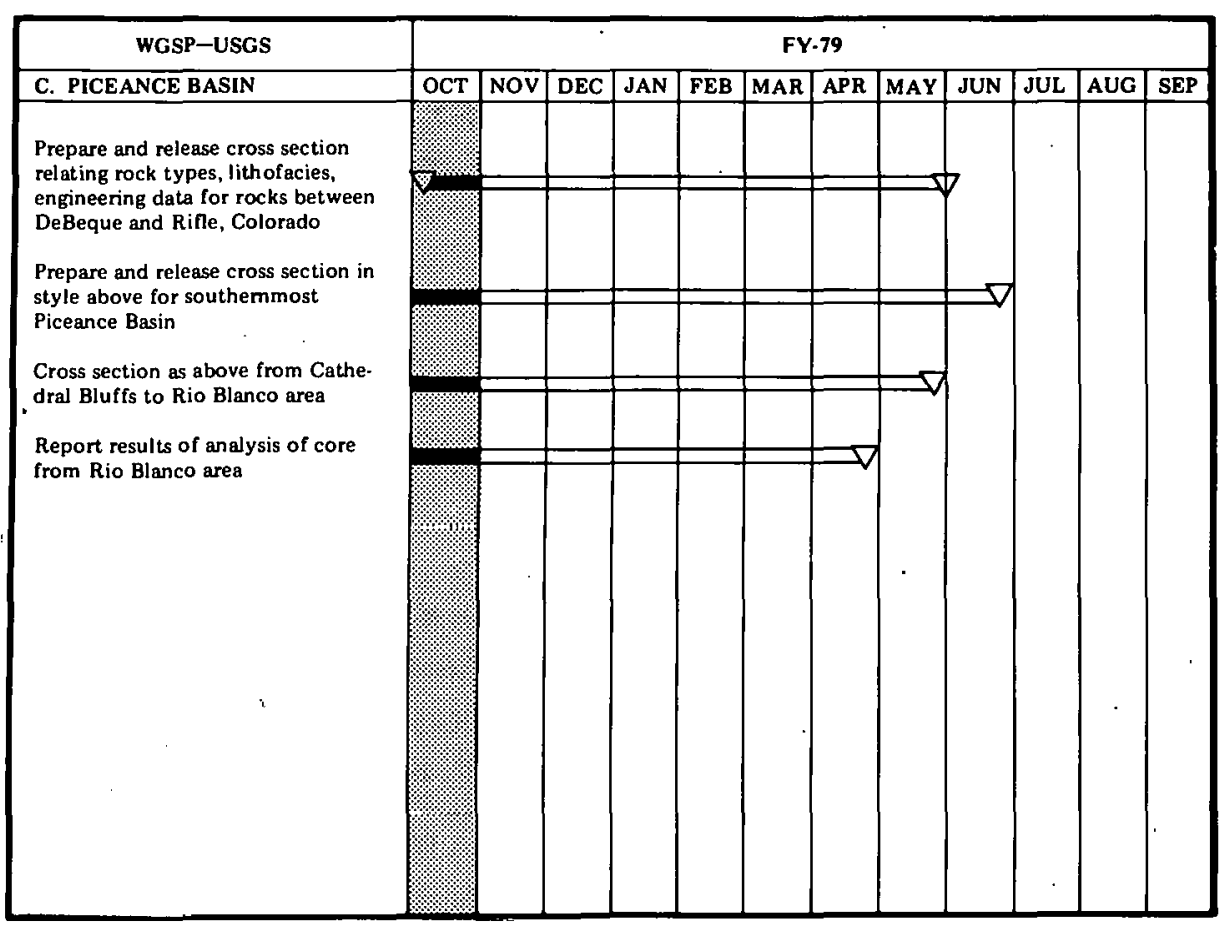

\begin{tabular}{|c|c|c|c|c|c|c|c|c|c|c|c|c|}
\hline . WGSP-USGS & \multicolumn{12}{|c|}{ FY-79 } \\
\hline D. UINTA BASIN & OCT & NOV & DEC & JAN & FEB & MAR & APR & MAY & JUN & JUL & AUG & SEP \\
\hline $\begin{array}{l}\text { Prepare and release cross section } \\
\text { relating rock types, lithofacies, }\end{array}$ & & & & & & & & & & & & \\
\hline $\begin{array}{l}\text { Wasatch Mountains to southcentral } \\
\text { Uinta Basin }\end{array}$ & & & & & & & & & & & & \\
\hline Investigate mineralogy and strati- & & & & & & & & & & & & \\
\hline $\begin{array}{l}\text { core from Southman Canyon region } \\
\text { of Uinta Basin }\end{array}$ & & & & & & & & & & & & \\
\hline $\begin{array}{l}\text { Analyze data from San Arroyo Wash } \\
\text { surface exposures of Cretaceous and }\end{array}$ & & & & & & & & & & & & \\
\hline $\begin{array}{l}\text { Basin. Report results as they become } \\
\text { available }\end{array}$ & & & & & & & & & & & & \\
\hline $\begin{array}{l}\text { Prepare report on "tight gas" reser- } \\
\text { voirs in Tertiary rocks of south- } \\
\text { central Uinta Basin. To be pub- } \\
\text { lished in SPE volume }\end{array}$ & & & & & & & & & & & & \\
\hline $\begin{array}{l}\text { Prepare report on diagenetic re- } \\
\text { actions and controls on Upper }\end{array}$ & & & & & & & & & & & & \\
\hline $\begin{array}{l}\text { Cretaceous gas reservoirs at South- } \\
\text { man Canyon Field, to be published } \\
\text { in SPE volume }\end{array}$ & & 2 & & & & & & & & & & \\
\hline $\begin{array}{l}\text { Core analysis-Upper Cretaceous } \\
\text { and Lower Tertiary units, south west } \\
\text { Uinta Basin }\end{array}$ & $x$ & & & & & & & & & & & \\
\hline
\end{tabular}

Figure 3-1 Continued 
The core interval in C\&K 4-14 is tentatively set at 950 to $1,210 \mathrm{ft}$, which corresponds to a similar depth in wells 1-13 and 1-13x.

Spud in is scheduled for November 18,1978 with the coring expected to take place from about November 22 through 24 .* $^{*}$

During the month, several operators were contacted for possible participation in the WGSP Core Program. In the Piceance Basin the operators were Adolph Coors of Golden, Colorado, Koch Exploration of Denver, Colorado and Dome Petroleum also in Denver. Odessa Natural, Odessa, Texas was contacted about a well they are planning to drill in the Uinta Basin. At month end, the only agreement made was with Twin Arrow.

In the Greater Green River Basin, True Oil Company and Michigan-Wisconsin Pipeline Company were contacted concerning potential core sites in Sweetwater County, Wyoming. DOE is interested in coring parts of the Fort Union, Lance, Lewis and Mesaverde from the well. Pacific Transmission Supply Company was contacted about a well in Sublette County, Wyoming. In this well, DOE is interested in coring parts of the Lower Tertiary and Mesaverde sections. DOE and PTS are working together on this well and may decide to negotiate a coring contract. Davis Oil was contacted to obtain core from their No. 1 Parish Mark Unit well in Sweetwater County, but were not able to participate because of lease obligations.

In Montana, Erico Resources of Denver was contacted about coring a well in Valley County, Montana. The sections of interest are in the Upper Cretaceous. Joseph J. C. Paine was also contacted for a potential site (Eagle) in the northern Bowdoin Dome area of Montana, as well as for a site (Judith River and Eagle) in the southeast part of the Cedar Creek Anticline, North Dakota.

\subsection{LOGGING PROGRAM}

The WGSP Logging Program meeting was held at CER offices, October 24, 1978. A list of those in attendance appears below:

Gerald Kukal
Robert Mann
Harry Newman
Charles Atkinson
Herb Carroll
Robert Clarke
Elena Clark
Joe Hearst
Merle Hanson
Jasper Jackson
Nick Vanderborgh

Gerald Kukal

Harry Newman

Charles Atkinson

Herb Carroll

Robert Clarke

Merle Hanson

Nick Vanderborgh
CER Corporation

CER Corporation

CER Corporation

DOE -BETC/NV

DOE -BETC

DOE -NV

Intercomp

Lawrence Livermore Lab.

Lawrence Livermore Lab.

Los Alamos Scientific Lab.

Los Alamos Scientific Lab.
Las Vegas, NV

Las Vegas, NV

Las Vegas, NV

Las Vegas, NV

Bartlesville, OK

Las Vegas, NV

Houston, TX

Livermore, CA

Livermore, CA

Los Alamos, NM

Los Alamos, NM

*Well cored on December 1 - 5, 1978 


\author{
W. F. Baldwin \\ Tom Dobecki \\ Peter Lysne \\ Carl Schuster \\ Ben Law \\ Ching Wu
}

\author{
Mobil Research \\ Sandia Laboratories \\ Sandia Laboratories \\ Sandia Laboratories \\ U.S. Geological Survey \\ U.S. Geological Survey
}

Dallas, TX

Albuquerque, NM

Albuquerque, NM

Albuquerque, NM

Denver, CO

Denver, CO

The purpose of the meeting was to discuss the WGSP Logging Program document, August 14, 1978 and define the problems that exist with logs in tight gas sands. Also discussed was the need to identify which reservoir parameters require better definition, and whether logging problems should be approached with existing tools, improved existing tools, or with the development of new tools. The research laboratories identified areas for their research and delineated research tasks. These tasks will be summarized in a revision to the WGSP Logging Program which is to be released in December.

An HP 67 calculator program has been prepared for use in WGSP log analysis.

The Twin Arrow well, C\&K 4-14 will be a part of the logging program. The well will be drilled with air-mist and a 7-7/8 in. drill bit. At the time of logging, the hole will be partially filled or totally filled with native water and with as much as 2 percent $\mathrm{KCl}$. The estimated resistivity of the mud filtrate is 0.3 and the estimated water resistivity (Mesaverde) is equal to 1.0 . The well will be drilled to a total depth of $2,100 \mathrm{ft}$ which is the base of the Castlegate Member of the Mancos Formation. The open hole logs to be run are: Dual Laterolog with gamma and SP, $\mathrm{R}_{\mathrm{xo}} \log$ (Microlaterolog, $\mu \mathrm{SFL}$, or Proximity), Dual Induction Laterolog 8 , Sonic BHC with gamma and caliper, Density log with caliper and gamma, Gamma Ray, Compensated Neutron, Spectral Gamma and Sidewall Cores.

\subsection{SURVEY OF BASIN ACTIVITIES}

Drilling and testing activities in the four primary study areas are monitored as part of assessing the resource and to identify possible core sites for the WGSP Coring Program. Figures 3-2 through 3-5 show recent wells with significance to the WGSP and to the core program. Background information on the core areas is given in the WGSP Quarterly Basin Activities Report, April 1, 1.978, NVO/0655-05.

\subsubsection{Greater Green River Basin}

During October thirteen development wells and four wildcats were completed in horizons of interest to the WGSP. Twelve development and three wildcats were on stream and a development and a wildcat well were completed D\&A. Producing horizons were the Fort Union (628 MCFD), Lewis (12,306 MCFD), commingled Almond/Lance (877 MCFD), Mesaverde (3,190 MCFD) and the Frontier (1,291 MCFD). Total production for the month was 18,292 MCFD. 
Forty-seven new wells with application to the WGSP were staked during October. Twentyfive wells were located in proven fields and 22 were in wildcat areas. Three of these wells were spudded and are drilling ahead at month end. Recent wells of interest are summarized in Table 3-1 and located on Figure 3-2.

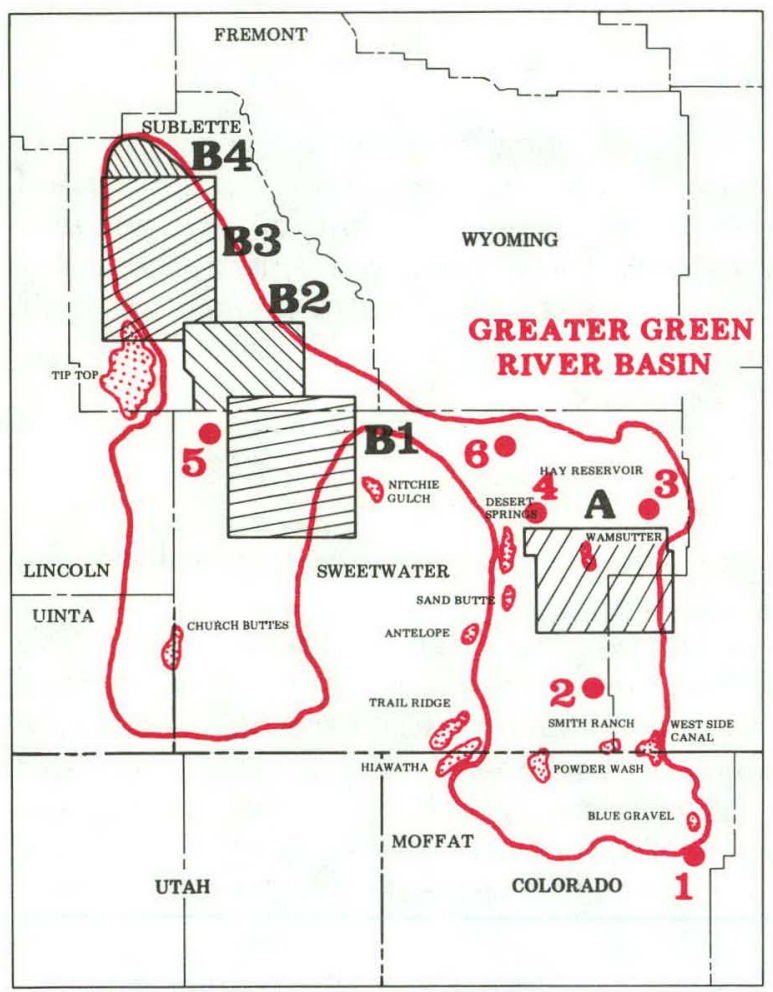

Figure 3-2

Greater Green River Basin Showing

Wells of Interest and USGS Desig-

nated Core Areas (refer to Table 3-1)

\subsubsection{Northern Great Plains Province}

The USGS has expanded the boundaries of the Northern Great Plains Province, effective October 1, 1978, to include the entire states of North and South Dakota. USGS in Denver has delineated the following reasons for this expansion.

- Chalks in the Greenhorn, Carlile and Niobrara Formations are developed over a large part of these states and are potential tight reservoirs. Active exploration for these chalks, particularly in the Niobrara, is occuring in Colorado, Kansas, and Nebraska and the interest is extending to the Dakotas where similar reservoirs exist.

- Previous and ongoing work by the USGS and South Dakota Geological Survey has shown that shales in the Pierre Shale and associated units are, in some places, extremely organic-rich and naturally fractured. Therefore the natural gas potential of these naturally fractured shales should be tested. Potential gas production, similar to that from the Devonian shales in the Appalachian Basin could be established using comparable technology. 
Table 3-1 Summary of Wells of Interest-Greater Green River Basin

\begin{tabular}{|c|c|c|c|c|c|c|c|c|}
\hline OPERATOR & WELL NAME & $\begin{array}{l}\text { MAP } \\
\text { INDEX } \\
\text { NO. }\end{array}$ & $\begin{array}{l}\text { LOCATION } \\
\text { Sec/T/R }\end{array}$ & HORIZON $^{2}$ & $\begin{array}{l}\text { FINAL } \\
\text { TD }\end{array}$ & $\begin{array}{l}\text { FRACTURE } \\
\text { TREATMENT }\end{array}$ & STATUS & $\begin{array}{l}\text { IPF in } \\
\text { MCFD }\end{array}$ \\
\hline $\begin{array}{l}\text { Chandler \&z } \\
\text { Assoc. }\end{array}$ & $\begin{array}{l}\text { 15-22 } \\
\text { McWilliams }\end{array}$ & 1 & $\begin{array}{l}\text { SWSE } \\
22 / 8 \mathrm{~N} / 90 \mathrm{~W} \\
\text { North Craig } \\
\text { Field } \\
\text { Moffat Cty, } \\
\text { Colorado }\end{array}$ & $\begin{array}{l}\text { Fort Union } \\
(1,120- \\
1,122) \\
\text { Lewis } \\
(2,491- \\
2,628)\end{array}$ & $\begin{array}{c}3,030 \\
\text { PB 2,640 }\end{array}$ & $\begin{array}{l}60,000 \mathrm{gal} \\
70,000 \mathrm{lb} \\
\text { sand }\end{array}$ & $\begin{array}{l}\text { Completed, } \\
\text { commingled } \\
\text { production }\end{array}$ & $\begin{array}{r}628 \\
1,232\end{array}$ \\
\hline $\begin{array}{l}\text { T'exas Oil \& } \\
\text { Gas }\end{array}$ & $\begin{array}{l}1 \text { Windmill } \\
\text { Draw }\end{array}$ & 2 & $\begin{array}{l}\text { NWSE } \\
14 / 15 \mathrm{~N} / 94 \mathrm{~W} \\
\text { Unnamed } \\
\text { Field } \\
\text { Sweetwater Cty, } \\
\text { Wyoming }\end{array}$ & $\begin{array}{l}\text { Almond } \\
(11,556- \\
11,606)\end{array}$ & $\begin{array}{l}12,575 \\
\text { PB } 11,800\end{array}$ & $\begin{array}{l}\text { Acidized- } \\
4,000 \mathrm{gal} \text {, } \\
178,500 \mathrm{gal} \\
\text { emulsion, } \\
253,250 \mathrm{lb} \\
\text { sand }\end{array}$ & Completed & 877 \\
\hline $\begin{array}{l}\text { Amoco } \\
\text { Production }\end{array}$ & $\begin{array}{l}1 \text { Bog Field } \\
\text { WI Unit }\end{array}$ & 3 & $\begin{array}{l}\text { NESW } \\
3 / 22 N / 91 W \\
\text { Wildeat Field } \\
\text { Sweetwater Cty, } \\
\text { Wyoming }\end{array}$ & Mesaverde & 15,832 & $\begin{array}{l}\text { Acidized- } \\
2,168 \text { gal }\end{array}$ & $\begin{array}{l}\text { Completed, } \\
\text { deep test } \\
\text { near core } \\
\text { site } \mathrm{A}\end{array}$ & D\&A \\
\hline $\begin{array}{l}\text { Amoco } \\
\text { Production }\end{array}$ & $\begin{array}{l}1 \text { Champlin } \\
438 \text { Amoco-A }\end{array}$ & 4 & $\begin{array}{l}\text { CSE } \\
5 / 22 N / 96 w \\
\text { Red Desert } \\
\text { Field } \\
\text { Sweetwater Cty, } \\
\text { Wyoming }\end{array}$ & Cretaceous & 13,040 & $\begin{array}{l}\text { Perfed } 9,536- \\
9,650, \\
10,217-10,255 \\
10,940-10,962\end{array}$ & $\begin{array}{l}\text { Completed, } \\
\text { near core } \\
\text { site A }\end{array}$ & D\&A \\
\hline Energetics Inc & 32-3 Federal & 5 & $\begin{array}{l}\text { SWNE } \\
3 / 25 N / 110 \text { W } \\
\text { Wildcat Field } \\
\text { Sweetwater Cty, } \\
\text { Wyoming }\end{array}$ & $\begin{array}{l}\text { Morrison } \\
(11,665)\end{array}$ & & & $\begin{array}{l}\text { Located, } \\
\text { near core } \\
\text { site B1 } \\
\text { and B2 }\end{array}$ & \\
\hline $\begin{array}{l}\text { Woods } \\
\text { Petroleum }\end{array}$ & $\begin{array}{l}2 \text { Lost } \\
\text { Valley Unit }\end{array}$ & 6 & $\begin{array}{l}\text { NWSE } \\
22 / 25 N / 99 \text { w } \\
\text { Wildcat Field } \\
\text { Sweetwater Cty, } \\
\text { Wyoming }\end{array}$ & $\begin{array}{l}\text { Baxter } \\
(13,000)\end{array}$ & & & Located & \\
\hline
\end{tabular}

${ }^{1}$ Refer to Figure $3-2$

${ }^{2}$ Horizon - projected depth or producing interval 
- Shelf sandstones of Late Cretaceous age and derived from the Sioux Uplift in southeastern South Dakota are developed throughout central and eastern South Dakota. These shelf sandstones are identical to those developed in Montana and are potential tight, gas-bearing reservoirs.

Activity in the Province continues to be concentrated in the northern counties of Montana. Thirty-four wells applicable to the WGSP were completed during the month of October. Twenty-two were located in proven gas fields in northern Montana and twelve were wildcats. Wildcat wells were only 17 percent successful, while development wells were 50 percent successful. The producing formations were the Eagle, Phillips, Bowdoin, Greenhorn and Bow Island. Total amount of gas produced was about 10,800 MCFD.

Thirty new wells were staked in the Upper Cretaceous Sands of the Northern Great Plains Province; seventeen development and thirteen wildcat wells. At month end six had been spudded and were drilling ahead, three were completed D\&A and one had reached total depth.

Activity relevant to the WGSP in North and South Dakota is limited at this time. Jerry McCutchin is active in the West Short Pine Hills Field, Harding County, South Dakota, and has plans to drill six or seven wells in the field area next year. Unichem International is evaluating the Niobrara Sand in south-central North Dakota. This well is located in Sioux County where the Niobrara will be tested through production casing due to inconclusive logs. Joseph J. C. Paine and Associates plan to drill three Judith River-Eagle wells in Bowman County, North Dakota. The wells are scheduled to test the Eagle at about 2,000 ft. Refer to Figure 3-3 and Table 3-2 for a listing and approximate location of recent wells of interest to the WGSP.

In the southern part of Montana, the Water Resources Division of the USGS is preparing to set 9-5/8 in. casing, apparently through the Madison, at a deep water evaluation well, located 10 miles northeast of Billings, Montana in Yellowstone County. Twenty-four cores over $30 \mathrm{ft}$ intervals between the Telegraph Creek (Cretaceous) and Cambrian are scheduled to be taken. J. E. Shackleford has a shallow test planned in Dawson County, Montana. This Dawson County wildcat well was previously drilled by Apache Corporation to 10,400 $\mathrm{ft}$ in 1976. A stratigraphic test is planned by Orlyn Terry in Carter County, Montana; the projected depth was not reported.

\subsubsection{Piceance Basin}

Wells completed during October in the Upper Cretaceous zones of the Piceance Basin produced 5,993 MCFD of gas. Nine wells were completed of which six were located in proven gas fields and three were wildcat locations with 33 percent success. The producing horizons and locations were the Wasatch and Douglas Creek zones in Piceance Creek Field, Rio Blanco County, the Mancos and Mancos B in the Cathedral Field, Rio Blanco County, and commingled Rollins/Cozzette/Corcoran in Plateau Field, Mesa County. 


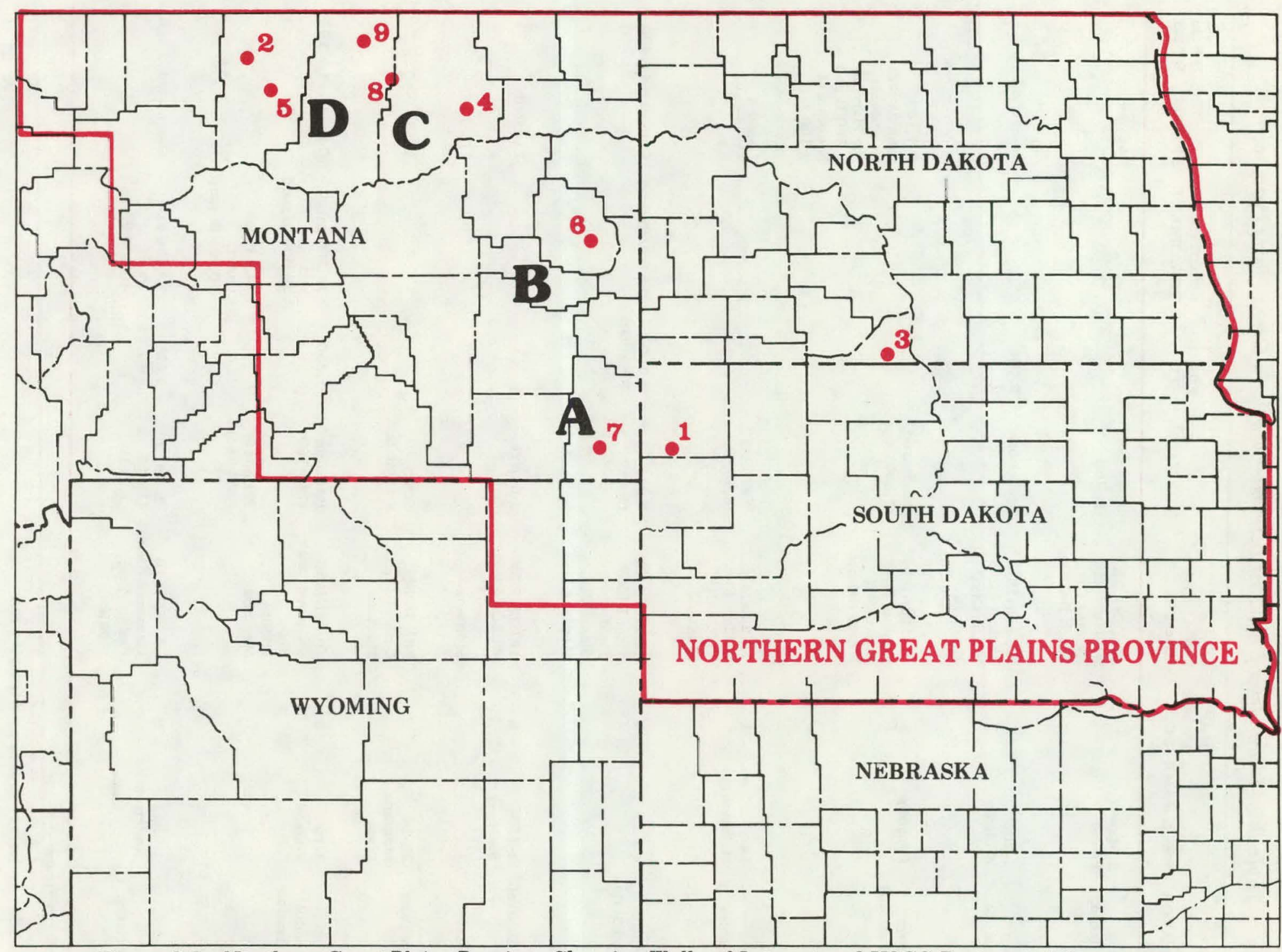

Figure 3-3 Northern Great Plains Province Showing Wells of Interest and USGS Designated Core Areas $A, B, C$ and $D$ (refer to Table 3-2) 
Table 3-2 Summary of Wells of Interest-Northern Great Plains Province*

\begin{tabular}{|c|c|c|c|c|c|c|c|c|}
\hline OPERATOR & WELL NAME & $\begin{array}{l}\text { MAP } \\
\text { INDEX } \\
\text { NO. }^{1}\end{array}$ & $\begin{array}{l}\text { LOCATION } \\
\text { Sec/T/R }\end{array}$ & HORIZON $^{2}$ & $\begin{array}{l}\text { FINAL } \\
\text { TD }\end{array}$ & $\begin{array}{l}\text { FRACTURE } \\
\text { TREATMENT }\end{array}$ & STATUS & $\begin{array}{l}\text { IPF in } \\
\text { MCFD }\end{array}$ \\
\hline $\begin{array}{l}\text { Jerry } \\
\text { McCutchin, } \\
\text { Jr. }\end{array}$ & $\begin{array}{l}1 \text { State- } \\
\text { Placid }\end{array}$ & 1 & $\begin{array}{l}16 / 15 \mathrm{~N} / 3 \mathrm{E} \\
\text { Wildcat Field } \\
\text { Harding Cty } \\
\text { South Dakota }\end{array}$ & $\begin{array}{l}\text { Shannon } \\
(1,300)\end{array}$ & & & Located & \\
\hline $\begin{array}{l}\text { Benson } \\
\text { Mineral } \\
\text { Group }\end{array}$ & $\begin{array}{l}\text { 1-20 } \\
\text { Williams }\end{array}$ & 2 & $\begin{array}{l}20 / 34 N / 18 E \\
\text { Wildcat Field } \\
\text { Blaine Cty, } \\
\text { Montana }\end{array}$ & Greenhorn & 2,404 & & Completed & \\
\hline $\begin{array}{l}\text { Unichem } \\
\text { International }\end{array}$ & 1 Jaco bs & 3 & $\begin{array}{l}7 / 129 \mathrm{~N} / 85 \mathrm{~W} \\
\text { wildcat Field } \\
\text { Sioux Cty, } \\
\text { North Dakota }\end{array}$ & $\begin{array}{l}\text { Deadwood } \\
(7,200)\end{array}$ & & & $\begin{array}{l}\text { @ } 7,168 \text {, } \\
\text { running logs } \\
\text { to evaluate } \\
\text { the Pierre at } \\
1.660 \mathrm{ft} \text { and } \\
\text { Niobrara at } \\
2,100 \mathrm{ft}\end{array}$ & \\
\hline $\begin{array}{l}\text { Erico } \\
\text { Resources }\end{array}$ & $\begin{array}{l}\text { 18-1 } \\
\text { Mcinty re }\end{array}$ & 4 & $\begin{array}{l}18 / 29 \mathrm{~N} / 41 \mathrm{E} \\
\text { Wildcat Field } \\
\text { Valley Cty, } \\
\text { Montana }\end{array}$ & $\begin{array}{l}\text { Winnipeg } \\
(8,350)\end{array}$ & & & Located & \\
\hline $\begin{array}{l}\text { Tricentrol } \\
\text { United States }\end{array}$ & 4-3 US & 5 & $\begin{array}{l}\text { 4/30N/18E } \\
\text { Tiger Ridge } \\
\text { Field } \\
\text { Blaine Cty, } \\
\text { Montana }\end{array}$ & $\begin{array}{l}\text { Eagle } \\
(1,442-\end{array}$ & $\begin{array}{l}1,700 \\
\text { PB } 1,570\end{array}$ & $15,000 \mathrm{lb}$ sand & Completed & 400 \\
\hline $\begin{array}{l}\text { J.E. Shackel- } \\
\text { ford }\end{array}$ & $\begin{array}{l}1-16 \\
\text { State }\end{array}$ & 6 & $\begin{array}{l}16 / 16 \mathrm{~N} / 55 \mathrm{E} \\
\text { Wildcat Field } \\
\text { Dawson Cty, } \\
\text { Montana }\end{array}$ & $\begin{array}{l}1,083 \mathrm{ft} \\
\text { test }\end{array}$ & & & Located & \\
\hline Ordyn Terry & $\begin{array}{l}\text { 36-16 } \\
\text { Montana } \\
\text { State }\end{array}$ & 7 & $\begin{array}{l}36 / 7 \mathrm{~S} / 58 \mathrm{E} \\
\text { Carter Cty, } \\
\text { Montana }\end{array}$ & $\begin{array}{l}\text { Strati- } \\
\text { graphic test }\end{array}$ & & & Located & \\
\hline $\begin{array}{l}\text { Falcon- } \\
\text { Colorado } \\
\text { Exploration }\end{array}$ & $\begin{array}{l}1-19 \\
\text { Federal }\end{array}$ & 8 & $\begin{array}{l}\text { 19/32N/35E } \\
\text { Swanson Creek } \\
\text { Field } \\
\text { Phillips Cty, } \\
\text { Montana }\end{array}$ & 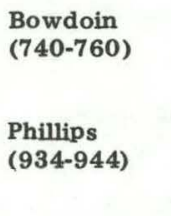 & 1,350 & $\begin{array}{l}14,300 \mathrm{gal} \\
\text { water, } \\
40,000 \mathrm{lb} \text { sand } \\
14,439 \mathrm{gal} \\
\text { watex, } \\
40,000 \mathrm{lb} \text { sand }\end{array}$ & Completed & 293 \\
\hline $\begin{array}{l}\text { Joseph J. C. } \\
\text { Paine \&. } \\
\text { Associates }\end{array}$ & $\begin{array}{l}1-0562 \\
\text { Anderson }\end{array}$ & 9 & $\begin{array}{l}5 / 36 \mathrm{~N} / 32 \mathrm{E} \\
\text { Unnamed Field } \\
\text { Phillips Cty, } \\
\text { Montana }\end{array}$ & $\begin{array}{l}\text { Bowdoin } \\
(1,352- \\
1,393)\end{array}$ & $\begin{array}{l}1,650 \\
\text { PB } 1,450\end{array}$ & $\begin{array}{l}13,356 \mathrm{gal} \\
\text { water. } \\
40,000 \mathrm{lb} \text { sand }\end{array}$ & Completed & 3,586 \\
\hline
\end{tabular}

${ }^{1}$ Refer to Figure 3-3

${ }^{2}$ Horizon - projected depth or producing interval 
Twenty-four new wells were staked during the month; ten wildcats and fourteen development wells. At month end two had been spudded and were drilling ahead and one well had been drilled to total depth. The new activity was concentrated in the North Douglas Creek Field, Rio Blanco County, where Chandler and Associates staked seven Mancos tests and in the Piceance Creek Field, Rio Blanco County, where the Wasatch was the major objective.

Table 3-3 is a summary of recent wells of interest to the WGSP and Figure 3-4 shows the well locations.

\subsubsection{Uinta Basin}

Only three wells were completed in the Uinta Basin with application to the WGSP during October. All three were Mesaverde producers and located in the Natural Buttes Field, Uintah County, Utah.

Eighteen new wells were staked during the month. Eleven of these were CIG Exploration wells located in the Natural Buttes Field and scheduled to test the Wasatch. There were also a couple of confidential tests in the Cedar Rim Field of Duchesne County, and two wildcat wells, one located in core area $\mathrm{D}$ and the other in core area $\mathrm{A}$.

Table 3-4 summarizes recent wells of interest to the WGSP and Figure 3-5 shows each well location within the basin. 
Figure 3-4

Piceance Basin Showing

Wells of Interest and USGS

Designated Core Areas

(refer to Table 3-3)

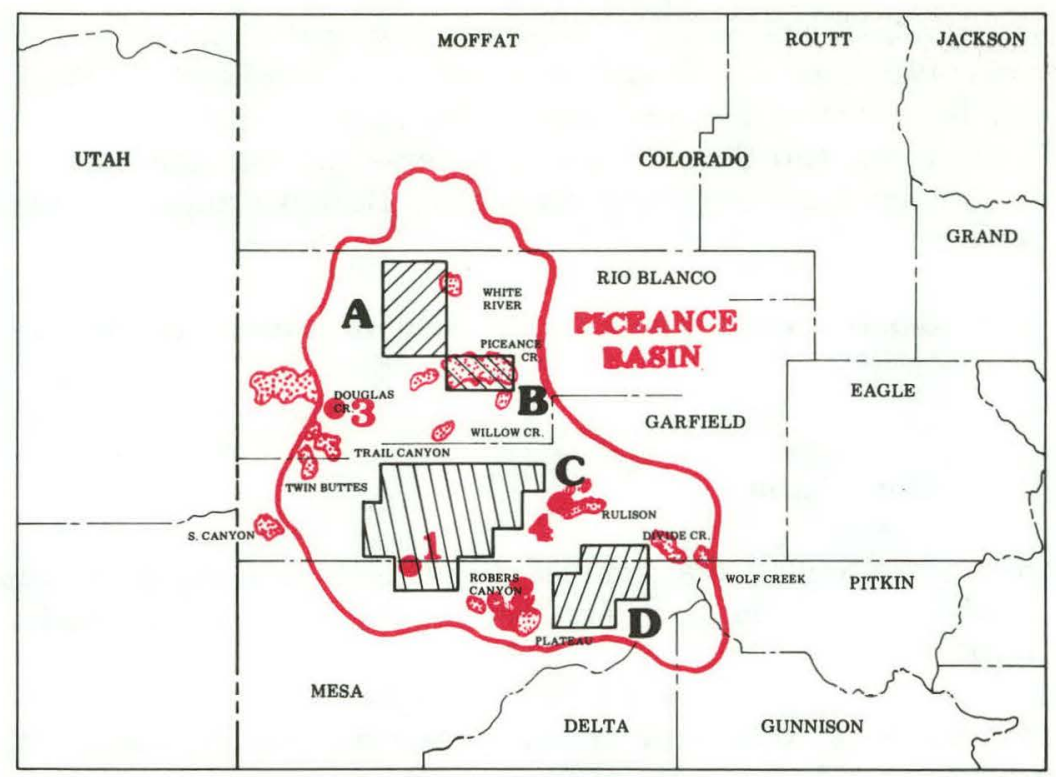

Table 3-3 Summary of Wells of Interest-Piceance Basin

\begin{tabular}{|c|c|c|c|c|c|c|c|c|}
\hline OPERATOR & WELL N AME & $\begin{array}{l}\text { MAP } \\
\text { INDEX } \\
\text { NO. }\end{array}$ & $\begin{array}{l}\text { LOCATION } \\
\text { Sec/T/R }\end{array}$ & HORIZON $^{2}$ & $\begin{array}{l}\text { FINAL } \\
\text { TD }\end{array}$ & $\begin{array}{l}\text { FRACTURE } \\
\text { TREATMENT }\end{array}$ & STATUS & $\begin{array}{l}\text { IPF in } \\
\text { MCFD }\end{array}$ \\
\hline $\begin{array}{l}\text { Koch } \\
\text { Exploration }\end{array}$ & 1 Federal & 1 & $\begin{array}{l}\text { NWNW } \\
13 / 8 S / 99 W \\
\text { Wildcat Field } \\
\text { Mesa Cty, } \\
\text { Colorado }\end{array}$ & $\begin{array}{l}\text { Dakota } \\
(6,800)\end{array}$ & & & Located & \\
\hline Norris Oil & 13-3 Finch & 2 & $\begin{array}{l}\text { NWNE } \\
13 / 10 S / 96 W \\
\text { Plateau Field } \\
\text { Mesa Cty, } \\
\text { Colorado }\end{array}$ & $\begin{array}{l}\text { Rollins } \\
(3,310-3,354) \\
\text { Cozzette } \\
(3,640-3,657) \\
\text { Corcoran } \\
(3,784-3,863)\end{array}$ & 4,008 & $\begin{array}{l}3,128 \mathrm{gal} \\
\text { water, } \\
517,000 \mathrm{lb} \\
\text { sand }\end{array}$ & $\begin{array}{l}\text { Commingled } \\
\text { completion }\end{array}$ & 1,734 \\
\hline $\begin{array}{l}\text { Fuel } \\
\text { Resources } \\
\text { Development }\end{array}$ & 23-1 Federal & 3 & $\begin{array}{l}\text { NENE } \\
23 / 3 S / 101 \mathrm{~W} \\
\text { Cathedral } \\
\text { Field } \\
\text { Rio Blanco Cty, } \\
\text { Colorado }\end{array}$ & $\begin{array}{l}\text { Mancos B } \\
(3,572-3,799)\end{array}$ & $\begin{array}{l}4,105 \\
\text { PB } 3,910\end{array}$ & $\begin{array}{l}73,400 \mathrm{gal} \\
195,000 \mathrm{lb} \\
\text { sand }\end{array}$ & Completed & 199 \\
\hline $\begin{array}{l}\text { Northwest } \\
\text { Exploration }\end{array}$ & 2 Clough & 4 & $\begin{array}{l}\text { SESW } \\
21 / 6 S / 94 W \\
\text { Rulison Field } \\
\text { Garfield Cty, } \\
\text { Colorado }\end{array}$ & $\begin{array}{l}8,700 \mathrm{ft} \\
\text { test }\end{array}$ & & & Located & \\
\hline
\end{tabular}

${ }^{1}$ Refer to Figure $\mathbf{3 - 4}$

${ }^{2}$ Horizon - projected depth or producing interval 


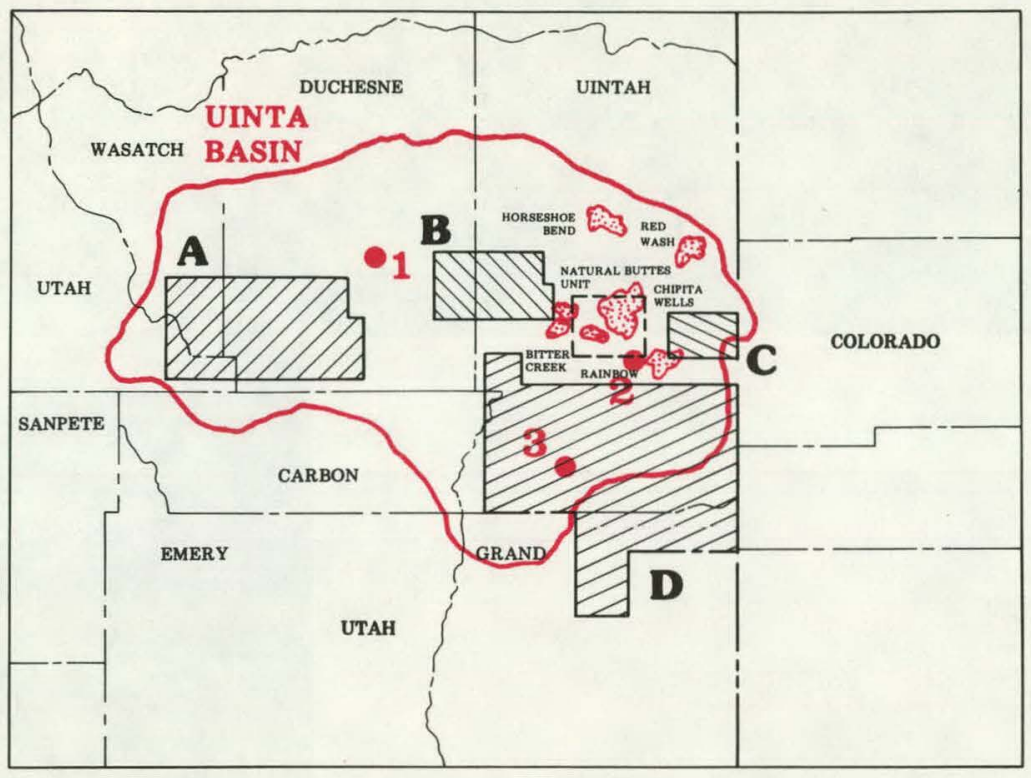

Figure 3-5

Uinta Basin Showing

Wells of Interest and USGS Designated Core Areas (refer to Table 3-4)

Table 3-4 Summary of Wells of Interest-Uinta Basin

\begin{tabular}{|c|c|c|c|c|c|c|c|c|}
\hline OPERATOR & WELL NAME & $\begin{array}{l}\text { MAP } \\
\text { INDEX } \\
\text { NO. }{ }^{1}\end{array}$ & $\begin{array}{l}\text { LOCATION } \\
\text { Sec/T/R }\end{array}$ & HORIZON $^{2}$ & $\underset{\text { TD }}{\text { FINAL }}$ & $\begin{array}{l}\text { FRACTURE } \\
\text { TREATMENT }\end{array}$ & STATUS & $\begin{array}{l}\text { IPF in } \\
\text { MCFD }\end{array}$ \\
\hline W.A. Moncrief & 8-1 Pender & 1 & $\begin{array}{l}\text { SESW } \\
8 / 2 S / 4 W \\
\text { Wildcat Field } \\
\text { Duchesne Cty } \\
\text { Utah }\end{array}$ & $\begin{array}{l}\text { Confidential } \\
\text { test }\end{array}$ & & & Located & \\
\hline $\begin{array}{l}\text { Gas } \\
\text { Producing }\end{array}$ & $\begin{array}{l}22 \text { Natural } \\
\text { Buttes Unit }\end{array}$ & 2 & $\begin{array}{l}\text { SENE } \\
18 / 10 \mathrm{OS} / 22 \mathrm{E} \\
\text { Natural Buttes } \\
\text { Field } \\
\text { Uintah Cty, } \\
\text { Utah }\end{array}$ & $\begin{array}{l}\text { Mesaverde } \\
(6,838-8,550)\end{array}$ & $\begin{array}{l}8,622 \\
\text { PB 8,615 }\end{array}$ & $\begin{array}{l}\text { Acidized- } \\
3,500 \text { gal, } \\
490,758 \text { gal } \\
\text { emulsion, } \\
1,151,000 \mathrm{lb} \\
\text { sand }\end{array}$ & Completed & 697 \\
\hline $\begin{array}{l}\text { Pacific } \\
\text { Transmission } \\
\text { Supply }\end{array}$ & 44-3 Federal & 3 & $\begin{array}{l}\text { SESE } \\
3 / 14 S / 20 E \\
\text { Wildcat Field } \\
\text { Uintah Cty, } \\
\text { Utah }\end{array}$ & $\begin{array}{l}\text { Mancos } \\
(7,000)\end{array}$ & & & Located & \\
\hline
\end{tabular}

${ }^{1}$ Refer to Figure 3-5

${ }^{2}$ Horizon - projected depth or producing interval 


\section{THIS PAGE WAS INTENTIONALLY LEFT BLANK}




\section{RESEARCH AND DEVELOPMENT BY ENERGY TECHNOLOGY CENTERS AND NATIONAL LABORATORIES}

\subsection{BARTLESVILLE ENERGY TECHNOLOGY CENTER}

\subsubsection{Improved Pressure Coring System}

\subsubsection{Core Retriever Design}

The completed Maurer engineering design is being used as part of the request for proposals being mailed to prospective industrial partners.

The purpose of the RFP is to solicit proposals based on the Maurer engineering design, modifications to this design, or any new design that incorporates the improvements in pressure coring that are the basis for the Maurer design. The proposals are to be for a joint industry and DOE cost-sharing development program to fabricate and field test an improved pressure coring system to be reported as a new task in FY 79.

\subsubsection{Coring Fluid Selection}

The water-based SANHEAL is still recommended for use with the new pressure coring system at this time, but continuing studies may identify other options.

\subsubsection{Bit Design}

The computer program for the 8-1/2 in. full body bit has been completed and the 9 in. diameter 9310 material is on hand. Fabrication of the $8-1 / 2$ in. bits will start as soon as time becomes available on the numerically controlled five axis machine. Pilot bit bodies are completed and awaiting diffusion bonding of the stratapax cutters.

\subsubsection{Interface Conductivity Effects on Electric Logging}

Resistivity measurements are continuing on core plugs from the Mesaverde formation. The following is a summary of data obtained from several plugs: 
Table 4-1 Summary of Core Measurements

\begin{tabular}{|c|c|c|c|c|c|}
\hline $\begin{array}{l}\text { Formation } \\
\text { Depth, ft }\end{array}$ & $\begin{array}{c}\text { Measured } \\
\text { Formation } \\
\text { Factor } \\
\text { "F" }\end{array}$ & $\begin{array}{c}\text { Permea } \\
\text { Gas, } \\
\text { micro- } \\
\text { darcies }\end{array}$ & $\begin{array}{l}\text { lity (k) } \\
\text { Liquid, } \\
\text { micro- } \\
\text { darcies }\end{array}$ & $\begin{array}{c}\text { Porosity } \\
(\phi)\end{array}$ & $\begin{array}{l}\text { Cementation } \\
\text { Factor } \\
\text { (M) }\end{array}$ \\
\hline 7,300 & 114 & 67.0 & 3.7 & 0.114 & 2.44 \\
\hline 7,530 & 295 & 43.8 & 5.6 & 0.072 & 2.16 \\
\hline 7,553 & 226 & 77.5 & 5.2 & 0.092 & 2.27 \\
\hline 7,900 & 172 & 26.5 & 3.1 & 0.085 & 2.09 \\
\hline 8,066 & 178 & 35.0 & 2.4 & 0.096 & 2.22 \\
\hline
\end{tabular}

Cores from Mobils' Piceance Creek Well were received and plugs will be tested as time permits.

Surface area measurements of several core samples are being made. Continuous flow equipment patterned after Nelson and Eagerton for surface area determination was checked with known surface area standards. In order to use this equipment, core samples must be crushed. Tests are underway to determine the effect of sample crushing.

An apparatus for determining the cation exchange capacity (CEC) of clay-containing core samples was assembled. Due to the time involved in the procedure and the anticipated number of samples, an automated CEC device was required. The most involved portion is the auto titration procedure, however, after sample preparation, CEC determination should require minimal attention.

\subsubsection{Logging Techniques and Interpretations}

\subsubsection{Study of Sonic, Neutron and Density Logging of Low Permeability Gas Sands-Texas A\&M University}

Study of the series of logs from Paine No. 1-0296 well in Montana with accompanying core data showed that, with two exceptions, the core data agreed with the porosity determined from the sonic log.

This analysis assumed a matrix density of between 2.65 and $2.68 \mathrm{gram} / \mathrm{cc}$ or travel time of 55.5 to $51.2 \mu \mathrm{sec} / \mathrm{ft}$. A slight variance of the matrix density for each area is necessary to obtain the porosity described in the core analysis. The density log consistently provides a porosity lower than that obtained in core analysis results. 


\subsubsection{Instrumentation for Formation Evaluation and Advanced Logging Techniques-Sandia Laboratories}

A logging task force was formed in February, 1978, and was chartered to investigate the state-of-the-art in commercial geophysical logs as well as logging research to determine which areas of concentration might be most beneficial to natural gas reservoir applications. Numerous months of literature search, theory development, and interviews with production and research personnel from the petroleum industry, academic community, and logging service organizations, indicates that the areas of NMR and electromagnetics would provide the most benefit. In addition, continuing research and development of existing Sandia borehole neutronics programs is encouraged with petroleum applications in mind. A working relationship with Chevron Oil Field Research Laboratories for NMR study of western gas sand formations has been developed, and a program for developing the pertinent electromagnetic theory linked to lab measurements has been initiated.

\subsubsection{Reservoir Stimulation Studies}

\subsubsection{Parametric Analysis of MHF Test Data; An Engineering Study of Western Gas Sands-Intercomp, Inc.}

Heber Cinco-L. and Fernando Samaniego-V. presented a paper titled Transient Pressure Analysis for Fractured Well at the Fall meeting of the SPE in Houston. The abstract of this paper appears in Section 2.2.2, "Articles and Publications" of this report. Four flow periods were defined. The first is linear flow from the fracture only. The second is bilinear flow. The third is for linear flow from the matrix alone and the fourth is for radial flow from the matrix.

The slope during the first flow period should be a straight line on a log $\Delta \mathrm{P}$ versus $\Delta t$ or type curve plot with a value of 0.5 . The second period should be a straight line of a slope of 0.25 on a type curve plot. The third flow period should have a slope of 0.5 on a type curve plot and the fourth should bend over.

The various flow periods may be present on any test or may be non-existent on any one test depending on the parameters of the reservoir. The first flow period may be mashed by storage effects, etc. The buildup tests for zone 1 and zone 3 of the Mobil well F31-13G show a slope of about 0.25 for the pre-frac tests. This slope was previously recognized and noted but the reason was unknown. It appears that zones 1 and 3 of the F31-13G well have natural fractures or that they were created during drilling or completion operations. Figure 4-1 is the type curve for zone 3 pre-frac build-up. It appears that the first two flow periods may be present. Seen on Figure 4-2, the first slope, notation 1 , is a 0.5 slope and the second slope, notation 2 , is a 0.27 slope. It appears that the third slope is not present. Cinco, et al states that this is true if $\mathrm{k}_{\mathrm{f}} \mathrm{w} /\left(\mathrm{kx}_{\mathrm{f}}\right)$ is $<1.6$. The nomenclature above is:

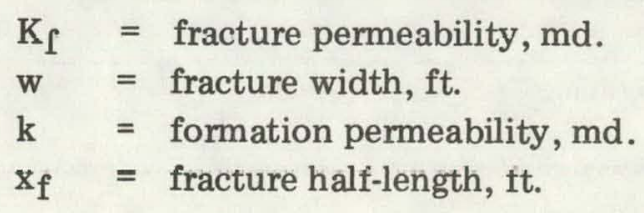




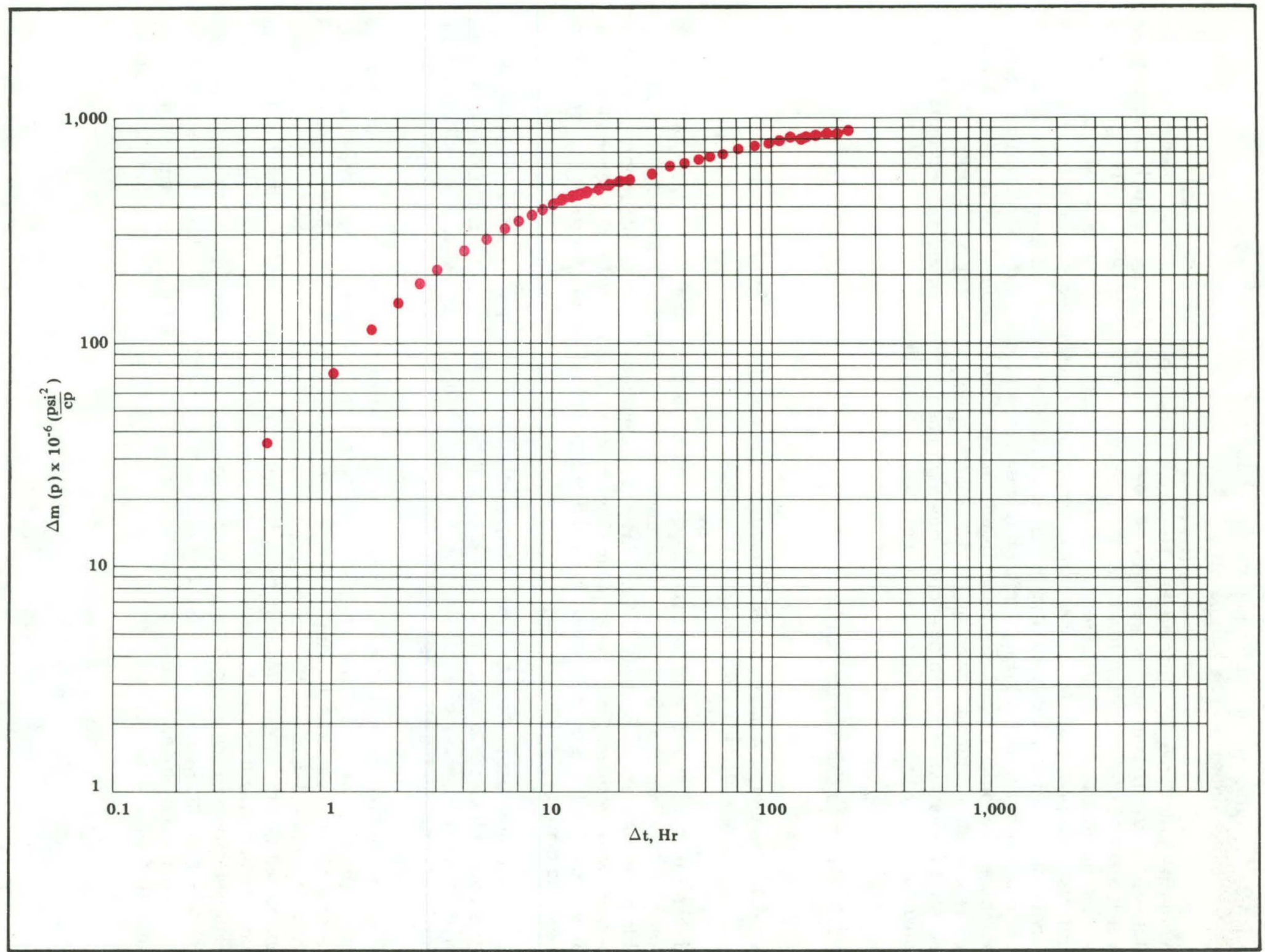

Figure 4-1 Type Curve Plot for Mobil Well F31-13G, Zone 3 Build-Up 


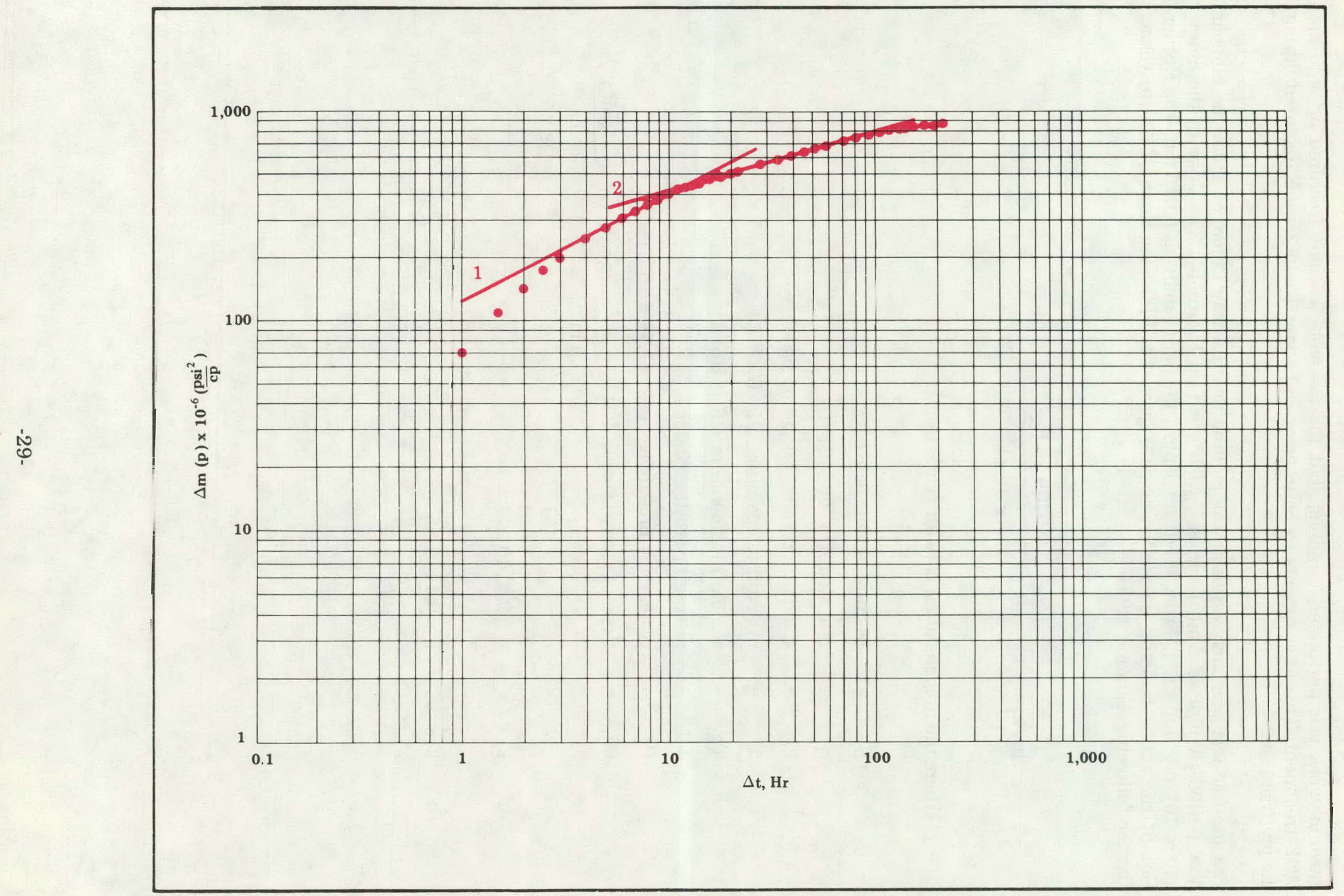

Figure 4-2 Type Curve Plot for Mobil Well F31-13G, Zone 3 Build-Up with Slopes Defined 
Previous work was performed assuming that the reservoir was not fractured prior to the MHF treatment. This now appears to be in error and zones 1 and 3 were fractured during the pre-frac tests.

The pre-frac test was analyzed using the method described by Cinco, et al for the bilinear flow period. A plot of $\Delta \mathrm{m}(\mathrm{p})$ versus ${ }^{4} \Delta \mathrm{t}$ is given on Figure 4-3. The slope of the line is $270 \times 10^{6} \mathrm{psi}^{2} /\left(\mathrm{cp} \mathrm{hr} \mathrm{hr}^{1 / 4}\right)$. From the Horner plot, the permeability is $0.019 \mathrm{md}$. The Horner plot of the actual build-up data is given on Figure 4-4. From the slope of $\Delta m(p)$ versus ${ }^{4} \Delta \mathrm{t}$ the following equation holds:

$$
\mathrm{h}_{\mathrm{f}} \sqrt{\mathrm{k}_{\mathrm{f}} \mathrm{w}} \quad \mathrm{k}^{1 / 4}=\frac{-15709 \mathrm{q} \mathrm{P}_{\mathrm{sc}^{\mathrm{T}}}}{\mathrm{T}_{\mathrm{sc}}\left(\phi \mu \mathrm{C}_{\mathrm{t}}\right)^{1 / 4} \mathrm{~m}_{\mathrm{bf}}}
$$

Where the nomenclature is (with values used):

$$
\begin{aligned}
& \mathrm{h}_{\mathrm{f}} \quad=\quad \text { fracture height, } \mathrm{ft}(61 \mathrm{ft}) \\
& \mathrm{q}=\text { rate } \mathrm{MCF} / \mathrm{D}(700 \mathrm{MCF} / \mathrm{D}) \\
& \mathrm{P}_{\mathrm{SC}} \quad=\quad \text { standard pressure, } \mathrm{psi}(14.65 \mathrm{psi}) \\
& \mathrm{T}=\text { reservoir temperature, }{ }^{\circ} \mathrm{R}\left(675^{\circ} \mathrm{R}\right) \\
& \mathrm{T}_{\mathrm{sc}}=\text { standard temperature, }{ }^{\circ} \mathrm{R}\left(520^{\circ} \mathrm{R}\right) \\
& \phi \quad=\quad \text { reservoir porosity, }(0.036) \\
& \mathrm{C}_{\mathrm{t}} \quad-\quad \text { system compressibility, } \mathrm{psi}^{-1}\left(1.74 \times 10^{-4} \mathrm{psi}^{-1}\right. \\
& \mathrm{m}_{\mathrm{bf}}=\text { slope of } \Delta \mathrm{m}(\mathrm{p}) \text { versus } \sqrt[4]{\Delta \mathrm{t}} \frac{\mathrm{psi}^{2}}{\mathrm{cp} \mathrm{hr}^{1 / 4}}\left(270 \times 10^{6} \frac{\mathrm{psi}^{2}}{\mathrm{cp} \mathrm{hr}^{1 / 4}}\right) \\
& \text { or } \mathrm{k}_{\mathrm{f}} \mathrm{w} \sqrt{\mathrm{k}}=0.4140 \\
& \text { so } \quad \mathrm{k}_{\mathrm{f}} \mathrm{W}=\frac{0.4140}{\sqrt{\mathrm{k}}}
\end{aligned}
$$




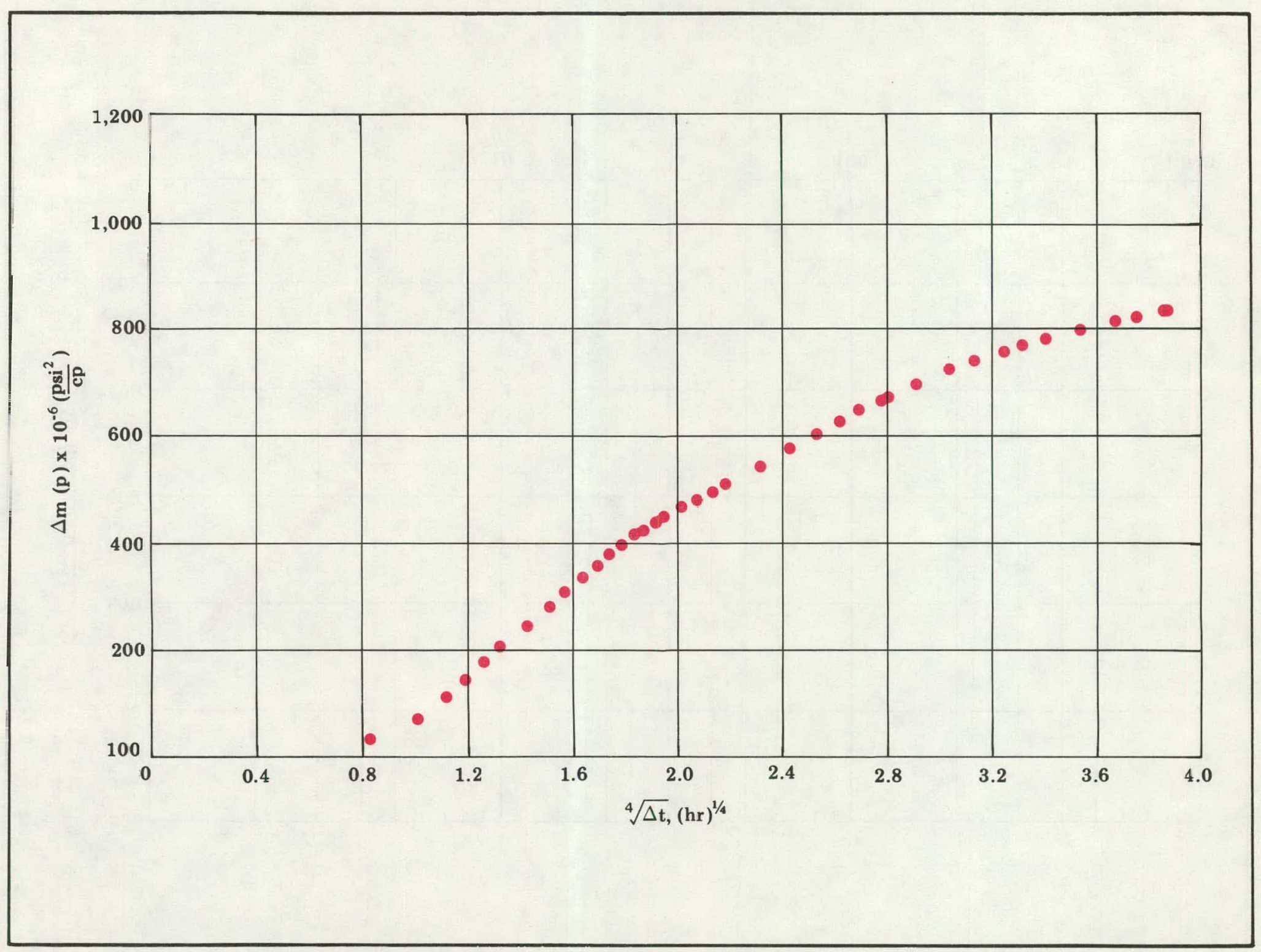

Figure 4-3 $\Delta m(p)$ versus $\sqrt[4]{\Delta t}$ for Mobil Well F31-13G, Zone 3, Pre-Frac Bulld-Up 


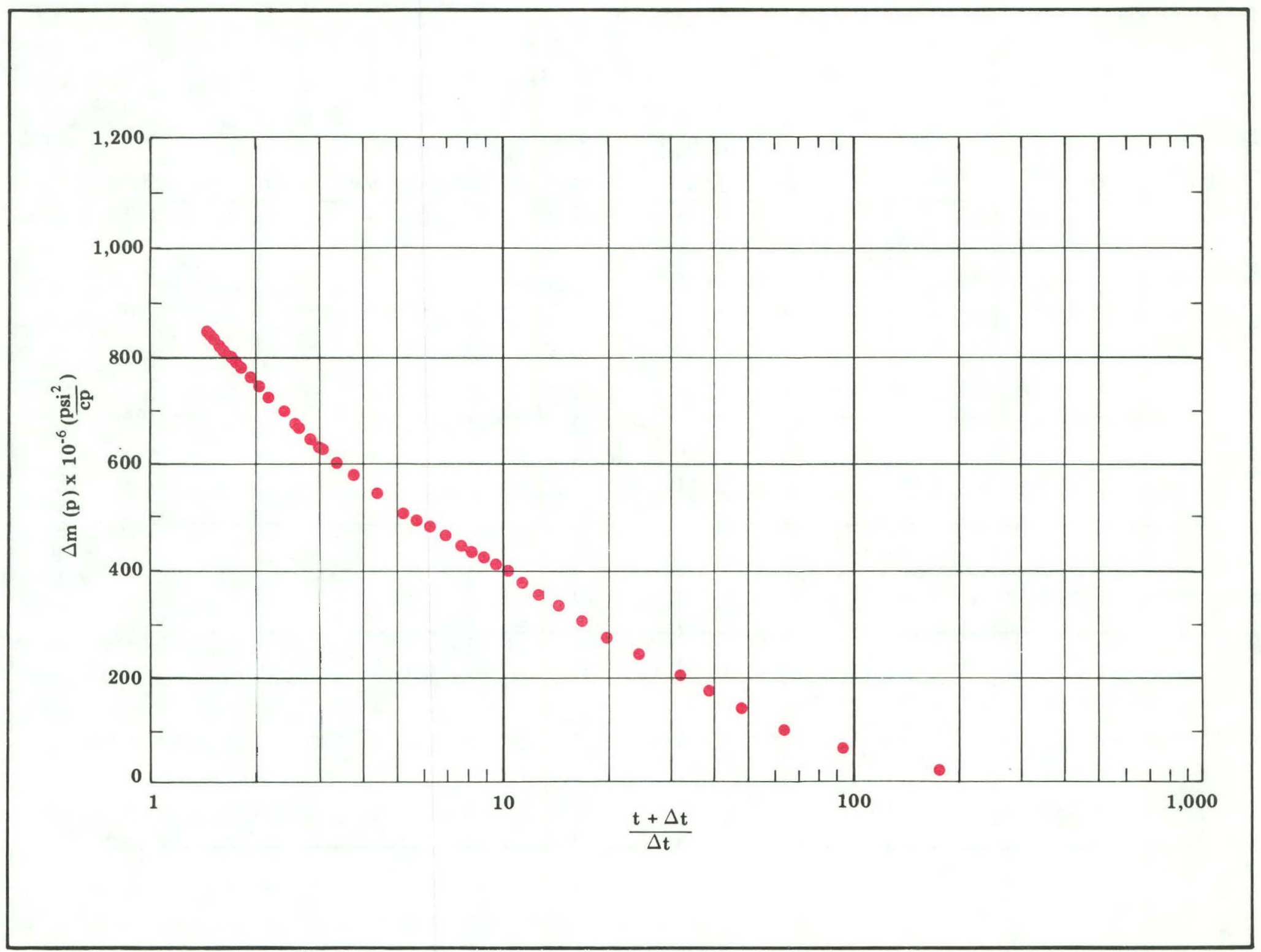

Figure 4-4 Horner Plot of Mobil Well F31-13G, Pre-Frac, Build-Up 
With this value as a starting point, several runs were attempted using values for wellbore storage fixed by the defined wellbore geometry. The run which gave the best result is shown in Figure 4-5 and is compared to the actual data on Figure 4-6. It can be seen from the figure that the curves match well at long times but the initial data appears to be in error. If the wellbore storage value is increased, the two curves should match, but there is no reason to assume the storage value is off very far, although it may be low. The important point is that the bilinear flow period appears to match.

The matrix permeability was increased to $0.0215 \mathrm{md}$. because the storage effects or rate effects on the build-up were still present. The analysis of a Horner plot of the simulated data will give a lower value of matrix permeability than actually used. The Horner plot of the simulated data is shown on Figure 4-7.

Zone 1 (type curve is given in September 30, 1978 Status Report, NVO/0655-112) pre-frac build-up has the same features as the zone 3 except the first flow period cannot be seen. It appears that the bilinear flow period lasts almost during the full test period for zone 1 .

\subsubsection{Future Work}

Data analysis will continue. It appears that some zones are fractured prior to MHF treatments. The analysis of the post MHF data will be re-analyzed with this in mind.

\subsubsection{Rock-Fluid Interaction}

Particle size distribution and numbers from 40-60 mesh sand placed 0.2 in. thick between two core halves have been obtained. A 10 in. long x 11/2 in. diameter Berea core was cut in half and reassembled with 0.2 in. fracture, packed with $40-60$ mesh sand. The assembled high-pressure core apparatus was arranged with the simulated fracture in the vertical position, then a 2 percent $\mathrm{KCl}$ solution pumped through the pack. The overburden pressure was increased in 1,000 psi increments starting at 1,000 psi and continuing up to $6,000 \mathrm{psi}$ Samples of the passing fluid were examined and the particles counted and sized. Generally, as the overburden pressure was increased the proppant particles were fractured and traveled in the 2 percent $\mathrm{KCl}$ solution. Table 4-2 shows the particle size and concentration in the effluent 2 percent $\mathrm{KCl}$ solution.

\subsubsection{Measurement of Formation Characteristics for Western Tight Sands- Institute of Gas Technology}

Initial results from the study of overburden pressure on gas permeability for several cores have correlated well with past data.

\subsubsection{Schedule Status}

Figure 4-8 is a milestone chart depicting the progress of projects undertaken by BETC for FY 1979 


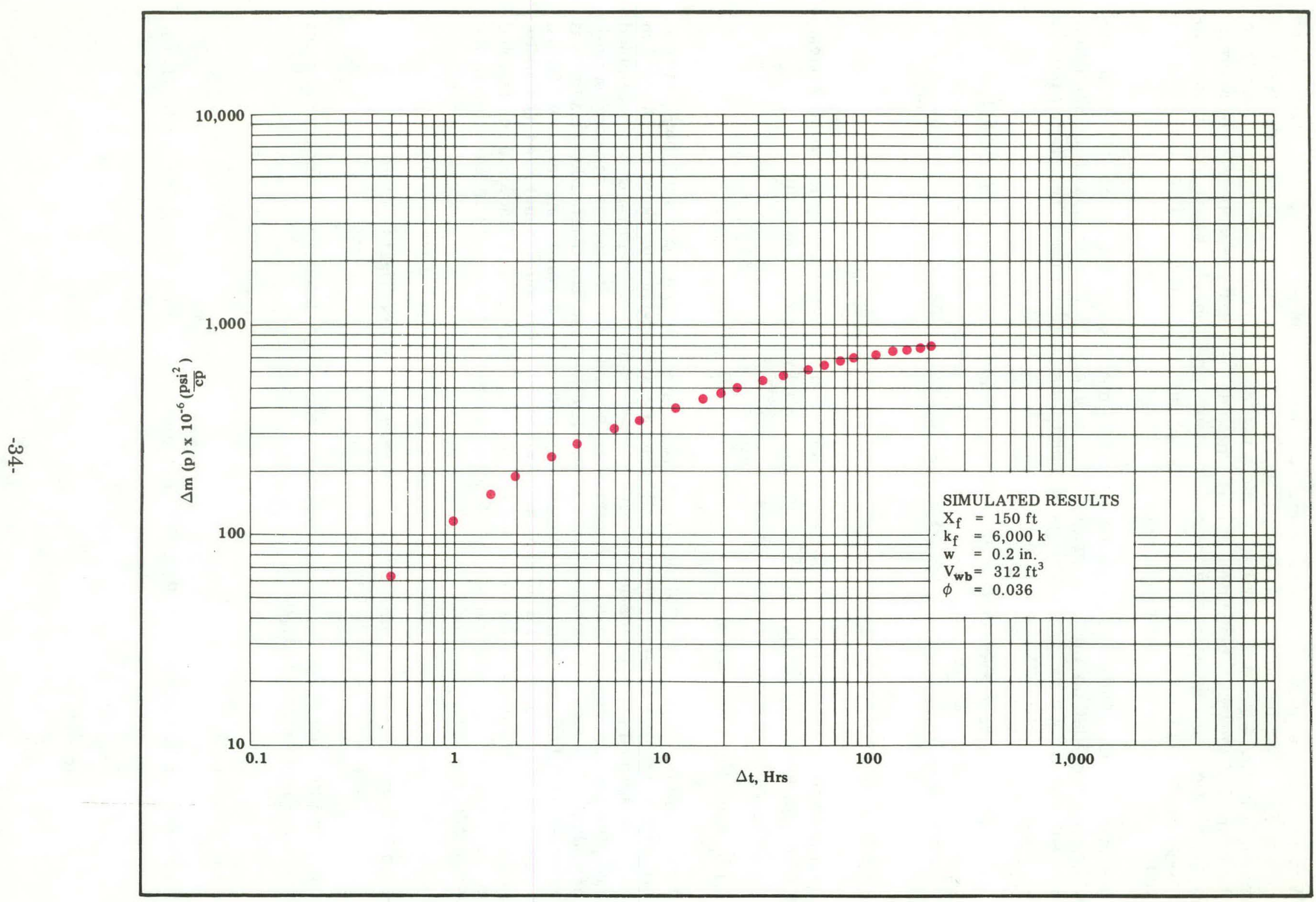

Figure 4-5 Type Curve Plot, Mobil Well F31-13G, Zone 3, Pre-Frac, Build-Up 


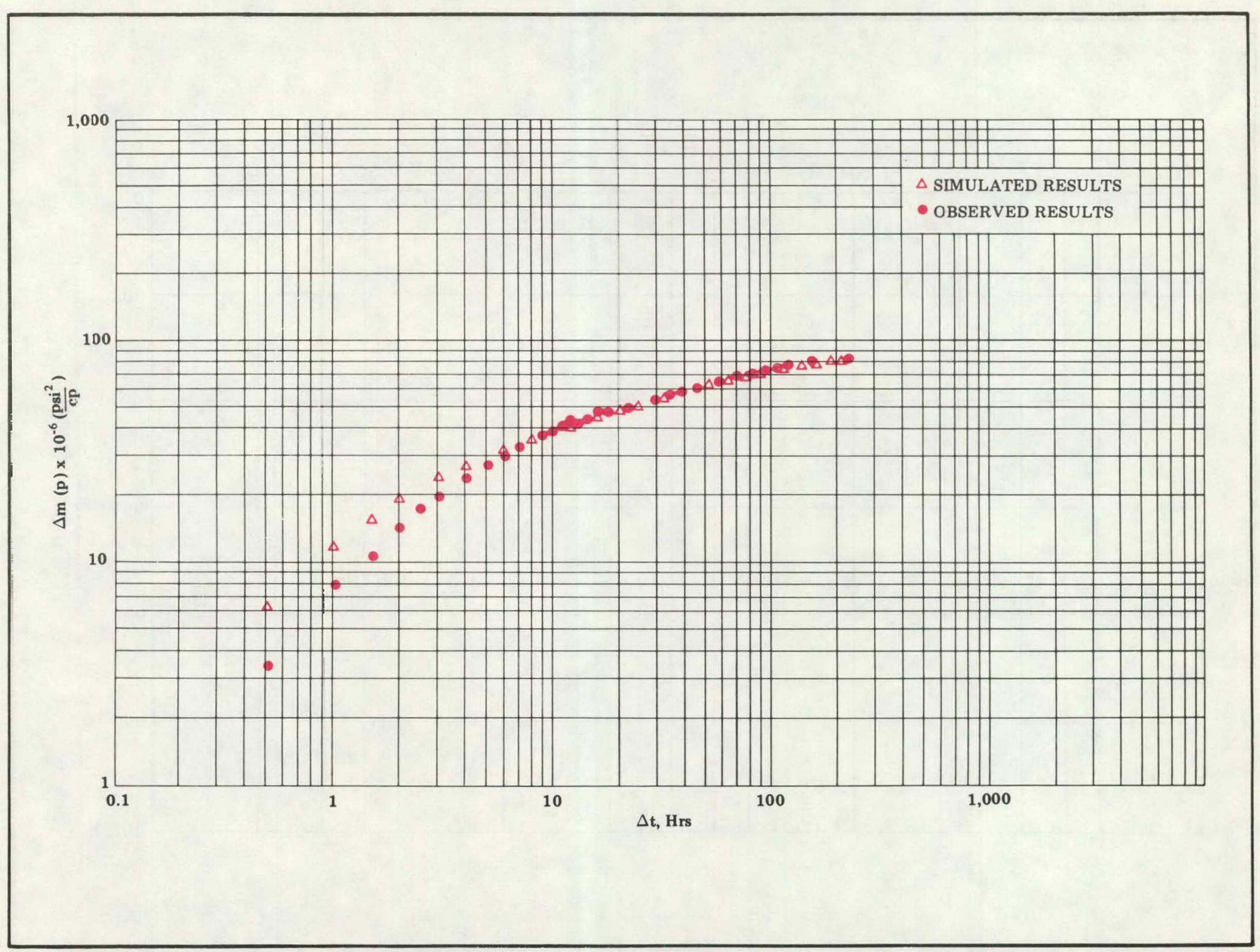

Figure 4-6 Type Curve, Mobil Well F31-13G, Pre-Frac Build-Up, Simulated and Observed Data 


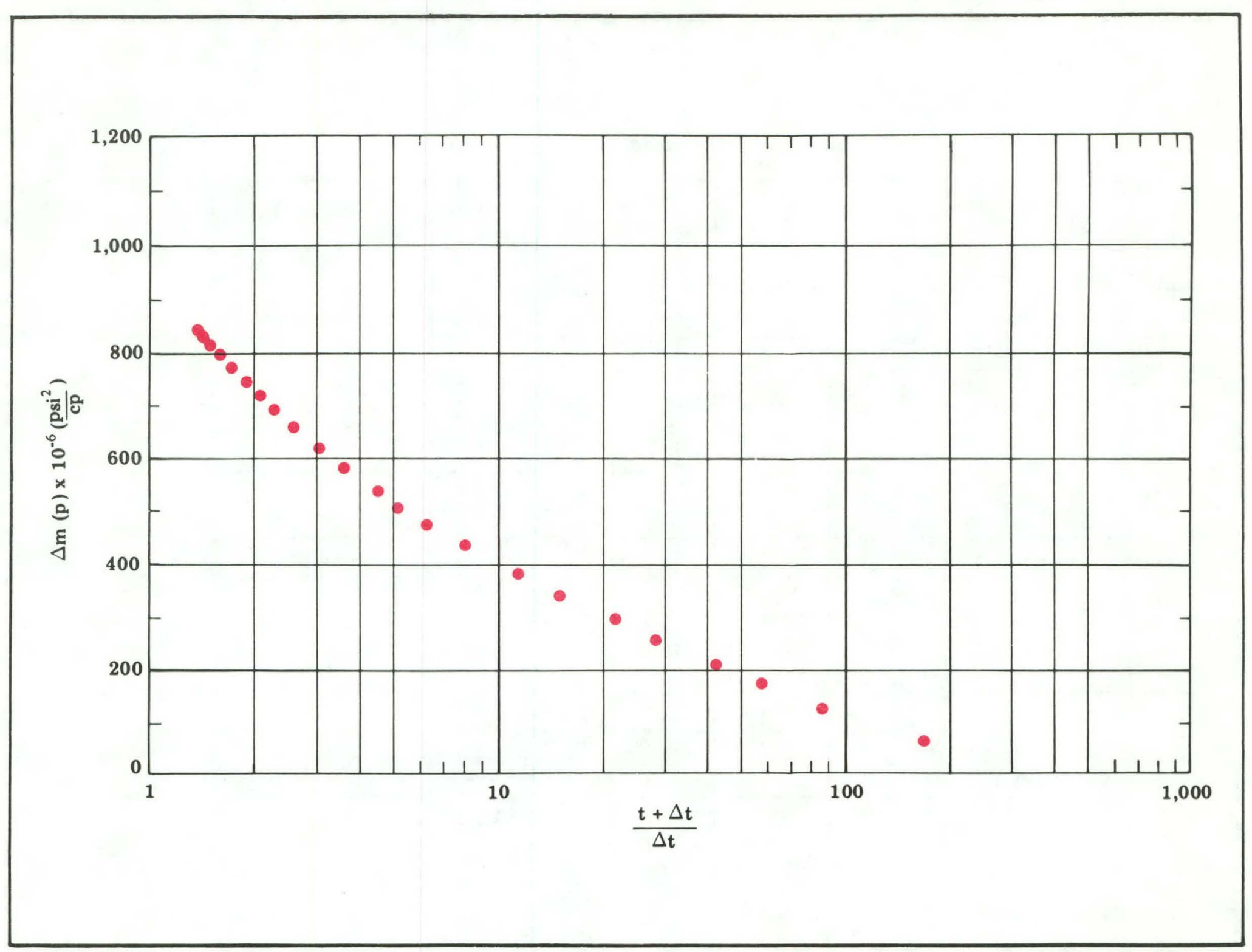

Figure 4-7 Horner Plot of Simulated Data for Zone 3 Pre-Frac, Build-Up Mobil F31-13G 
Table 4-2 Particle Size Distribution in Simulated Frac Fluid

\begin{tabular}{|c|c|c|c|c|c|}
\hline \multirow{2}{*}{$\begin{array}{l}\text { SAMPLE } \\
\text { NO. }\end{array}$} & \multirow{2}{*}{$\begin{array}{l}\text { OVERBURDEN } \\
\text { PRESSURE } \\
\text { (psi) }\end{array}$} & \multirow{2}{*}{$\begin{array}{l}\text { MAXIMUM } \\
\text { COUNTS } \\
\text { per ml }\end{array}$} & \multicolumn{3}{|c|}{$\begin{array}{l}\text { PARTICLE SIZE } \\
\text { IN MICRONS }\end{array}$} \\
\hline & & & Mean & Mode & Range \\
\hline 1 & 1,000 & 27,000 & 2.1 & 1.8 & $1.6--6.8$ \\
\hline 2 & 2,000 & 13,000 & 2.7 & 1.8 & $1.6-6.2$ \\
\hline 3 & 3,000 & 62,000 & 2.5 & 1.8 & $1.6-6.3$ \\
\hline 4 & 4,000 & 53,000 & 2.2 & 1.8 & $1.6-5.5$ \\
\hline 5 & 5,000 & 53,000 & 2.2 & 1.8 & $1.6-5.8$ \\
\hline 6 & 6,000 & 57,000 & 2.4 & 1.8 & $1.6-7.8$ \\
\hline
\end{tabular}




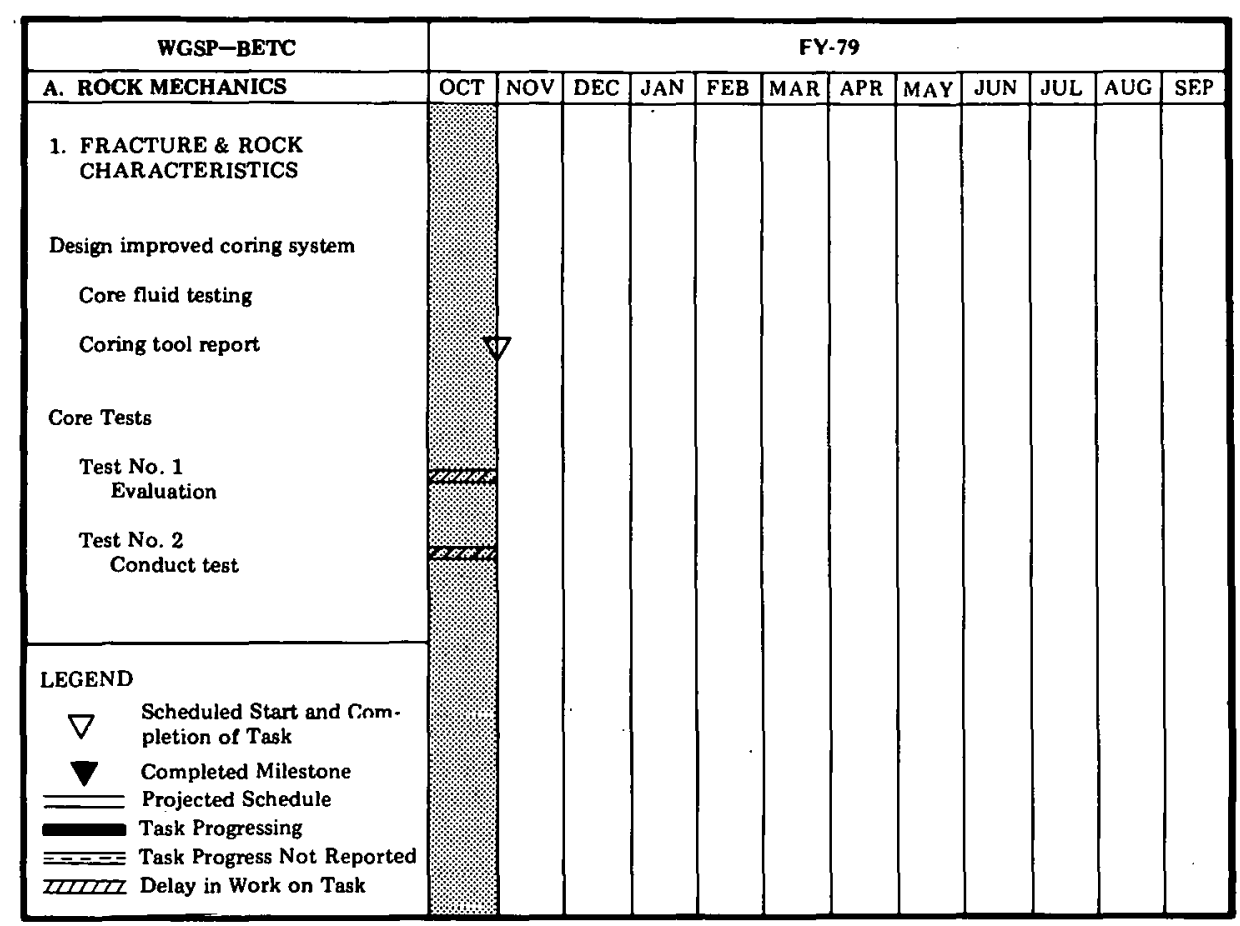

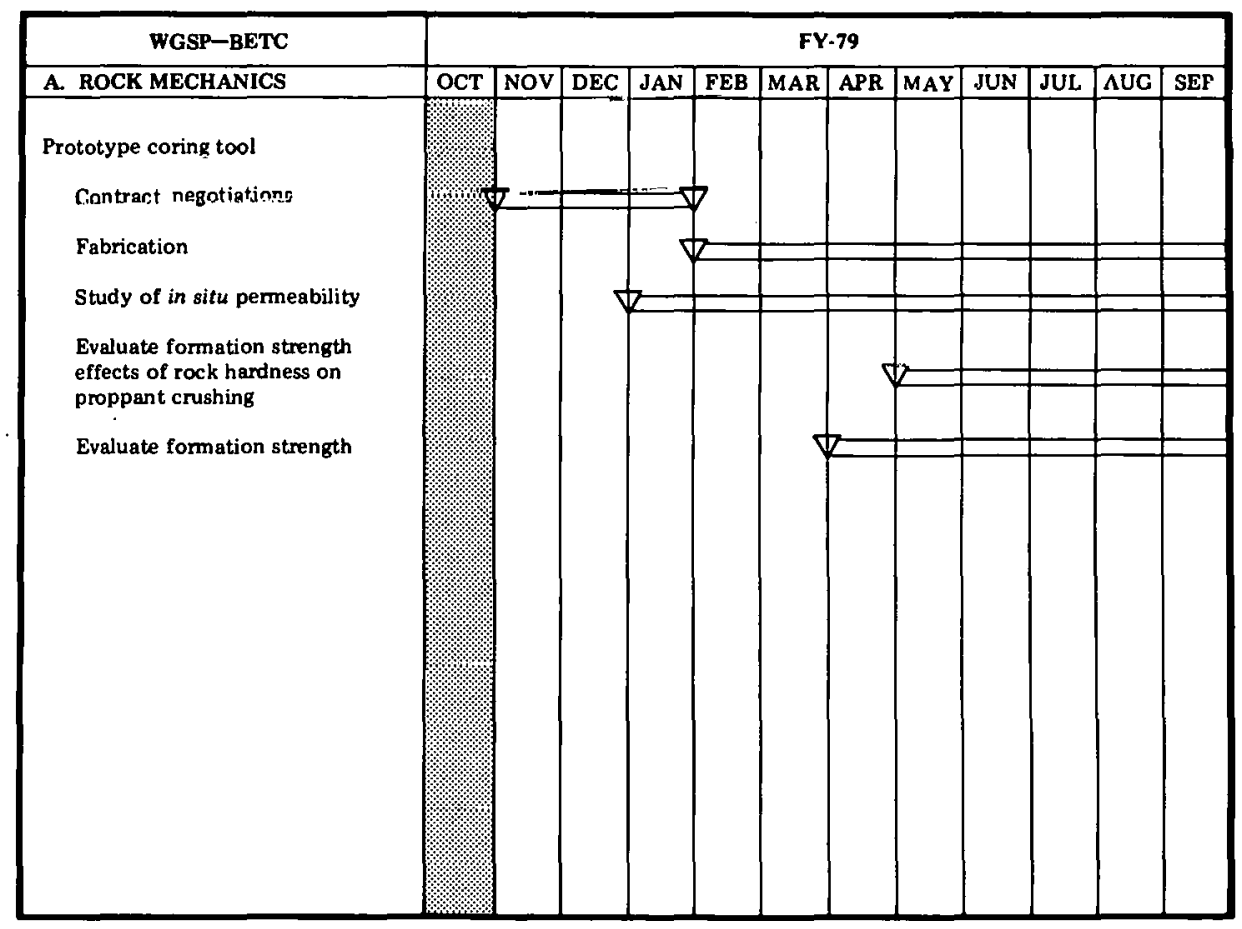

Figure 4-8 Milestone Chart-BETC 


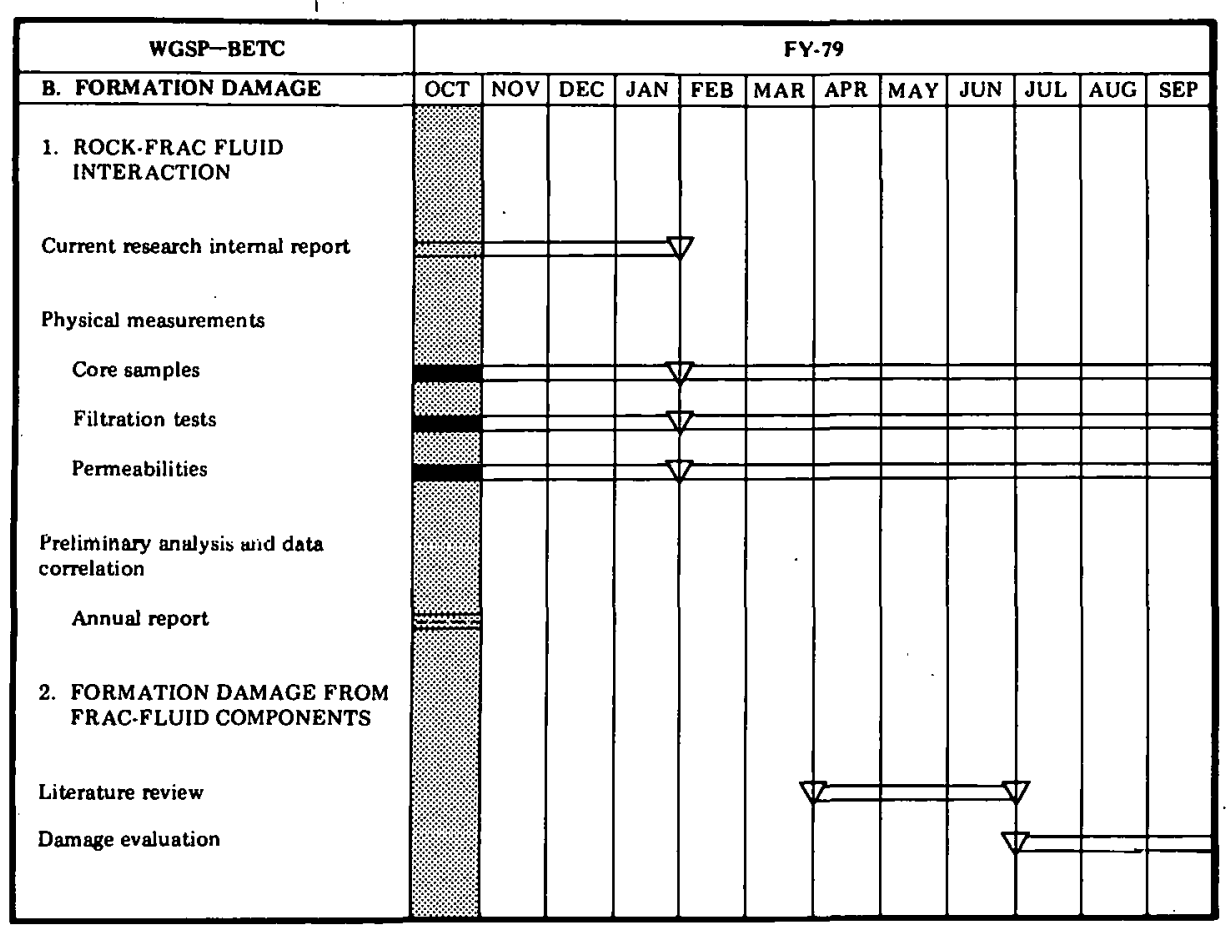

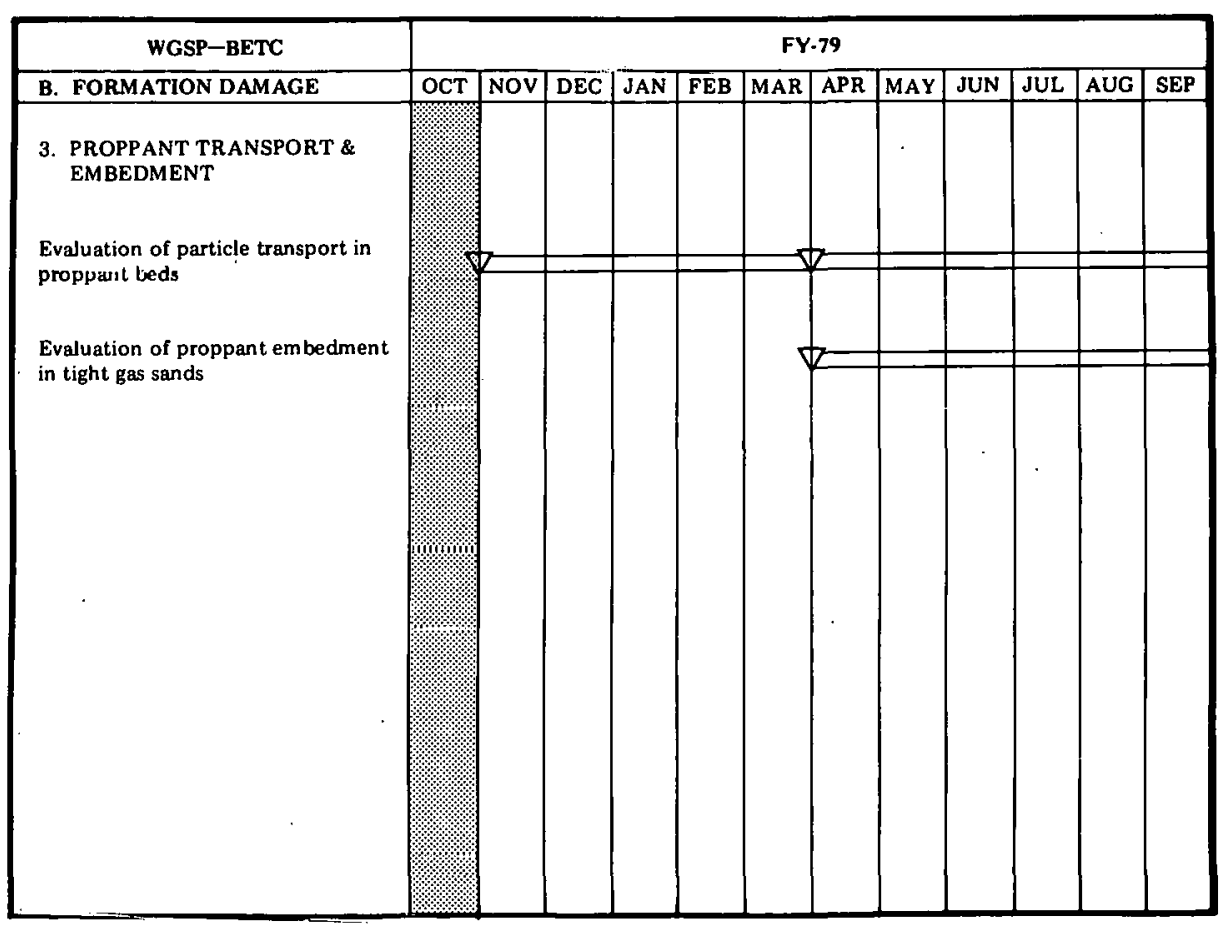

Figuro 4.8 Continued. 


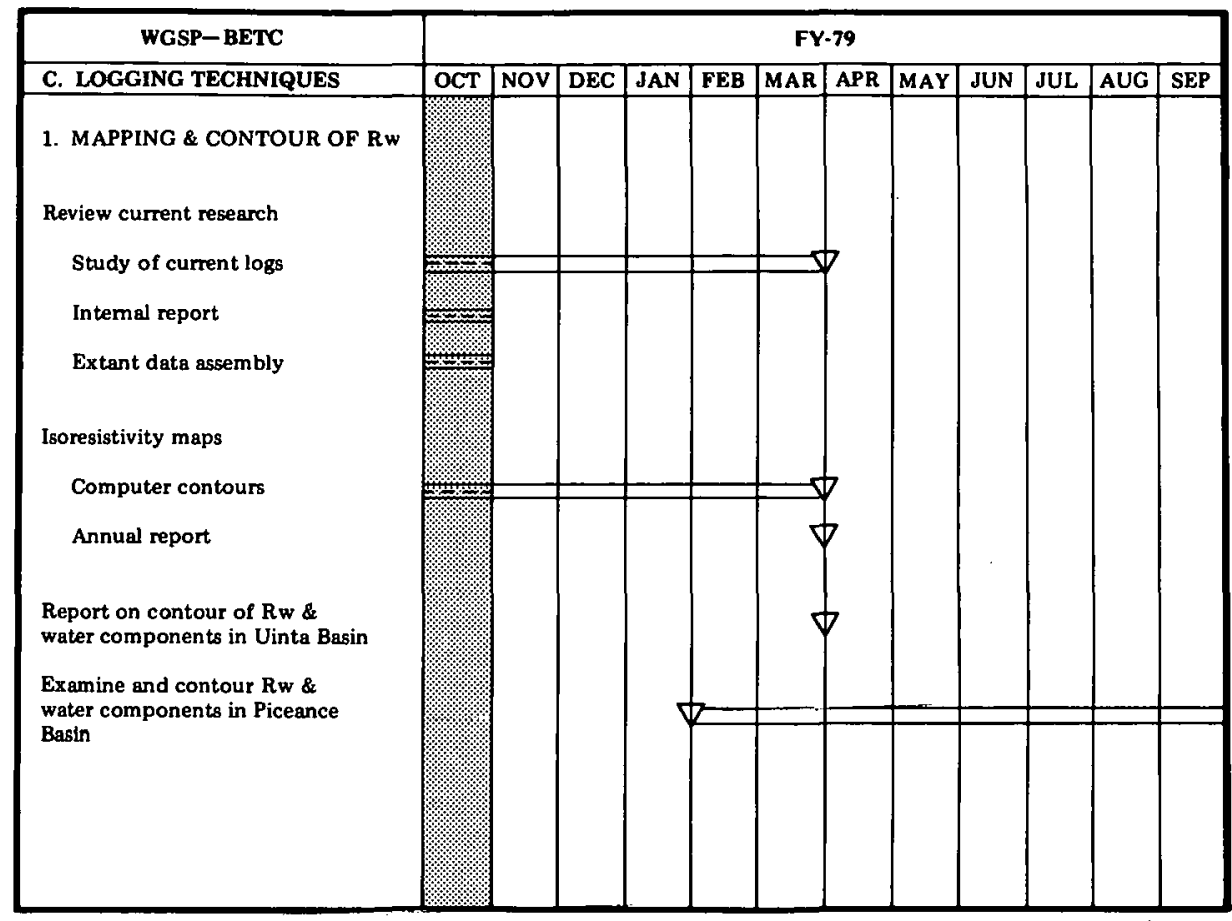

\begin{tabular}{|c|c|c|c|c|c|c|c|c|c|c|c|c|}
\hline WGSP-BETC & \multicolumn{12}{|c|}{ FY.79 } \\
\hline C. LOGGING TECHNIQUES & OCT & NOV & DEC & JAN & FEB & MAR & APR & MAY & JUN & JUL & $A \cup G$ & SEP \\
\hline \multicolumn{13}{|l|}{ 2. LOGGING EVALUATION } \\
\hline \multicolumn{13}{|l|}{$\begin{array}{l}\text { Effects of interface conductivity } \\
\text { on electric logging }\end{array}$} \\
\hline \multicolumn{13}{|l|}{ Physical measurements } \\
\hline \multicolumn{13}{|l|}{ Core preparation \& selection } \\
\hline \multicolumn{13}{|l|}{ Resistivily } \\
\hline \multicolumn{13}{|l|}{ Data correlations } \\
\hline \multicolumn{13}{|l|}{$\begin{array}{l}\text { Conductivities from Rink \& } \\
\text { Shopper equation }\end{array}$} \\
\hline \multirow{2}{*}{\multicolumn{13}{|c|}{ Permeabilities }} \\
\hline & & & & & & & & & & & & \\
\hline \multicolumn{13}{|l|}{ Report } \\
\hline \multicolumn{13}{|l|}{ Study of Logging Techniques } \\
\hline \multicolumn{13}{|l|}{ Neutron log data evaluation } \\
\hline Acoustic log data evaluation & & & & & & & & & & & & \\
\hline & & & & & & & & & & & & \\
\hline
\end{tabular}

Figure 4-8 Continued 


\begin{tabular}{|l|l|l|l|l|l|l|l|l|l|l|l|l|}
\hline WGSP-BETC & \multicolumn{9}{c|}{ FY.79 } \\
\hline C. LOGGING TECHNIQUES & OCT & NOV & DEC & JAN & FEB & MAR & APR & MAY & JUN & JUL & AUG & SEP \\
\hline $\begin{array}{l}\text { Density log data evaluation } \\
\text { Report on neutron, acoustic \& } \\
\text { density logs }\end{array}$ \\
$\begin{array}{l}\text { Evaluate N.M.R. \& electric logs } \\
\text { Contract negotiations } \\
\text { Evaluation }\end{array}$ \\
$\begin{array}{l}\text { 3. IN SITU Rw INSTRUMENT } \\
\text { Fvaluate Rw techniques }\end{array}$ \\
$\begin{array}{l}\text { Report } \\
\text { Feasibility study-instrument design } \\
\text { for in situ Rw measurements } \\
\text { Contract negotiations } \\
\text { Conduct study }\end{array}$ \\
\hline
\end{tabular}

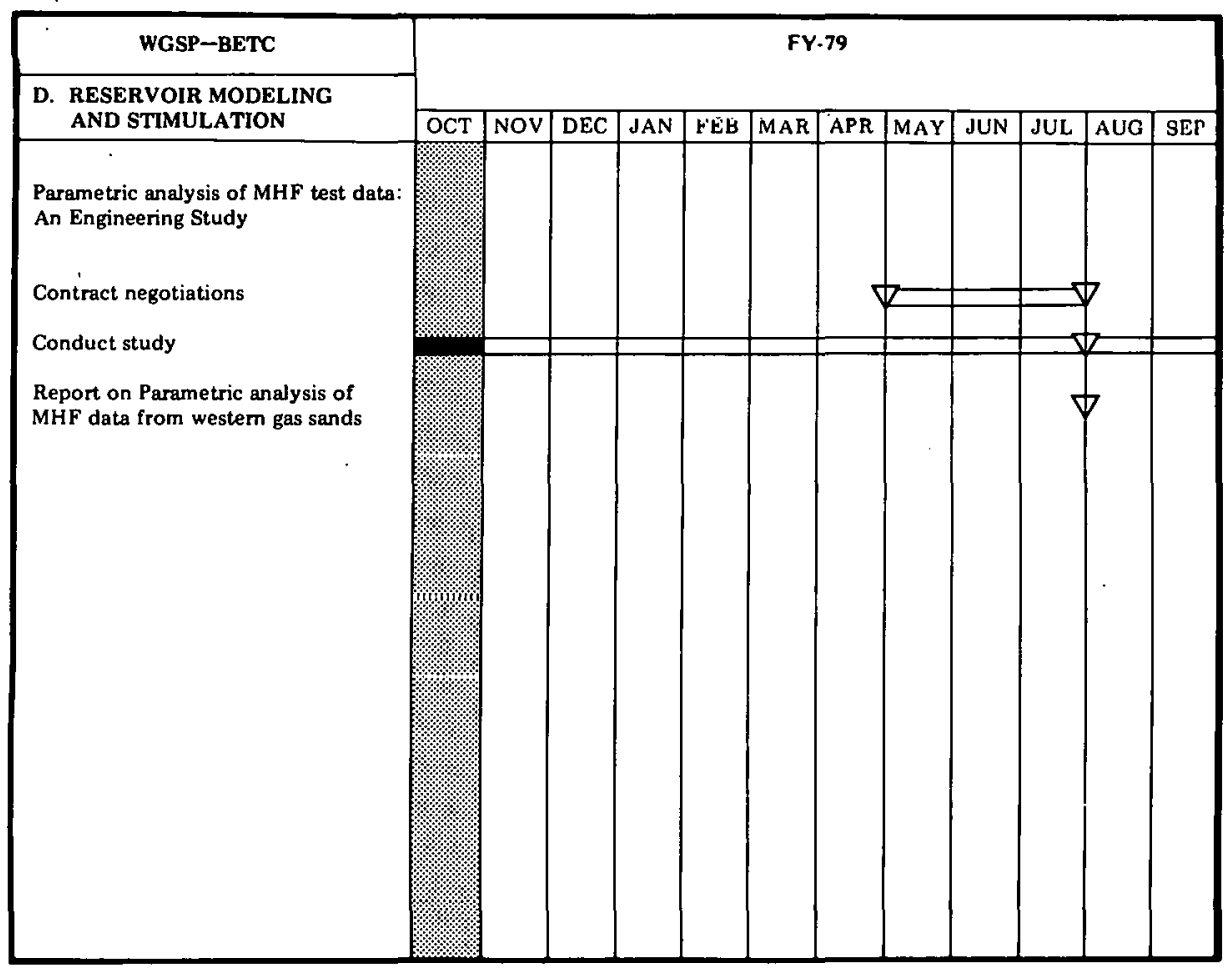

Figure 4-8 Continued 


\subsection{LAWRENCE LIVERMORE LABORATORY}

\subsubsection{Theoretical Analysis and Model Development-Results}

\subsubsection{Interface Calculations}

The preliminary model to include the effects of friction on an interface has been developed, written in Fortran, and is currently being debugged. For comparison with the forthcoming calculations with a frictional interface, a series of calculations for a crack approaching a well bonded interface between two materials has been completed. The materials on either side of the interface were defined having identical Poisson's ratios with different Young's moduli. The medium around the pressurized fracture was assumed to be impermeable and the pressure in the crack was taken as constant. Two sets of calculations were performed, one with the pressurized crack in the lower modulus material and the higher modulus material across the interface and the other set of calculations had the material moduli interchanged. The calculations were performed in two dimensions for plane strain. Figure 4-9 shows the geometry of the problem. The distance, $\xi$, of the fracture tip to the interface has been non-dimensionalized with respect to the crack length.

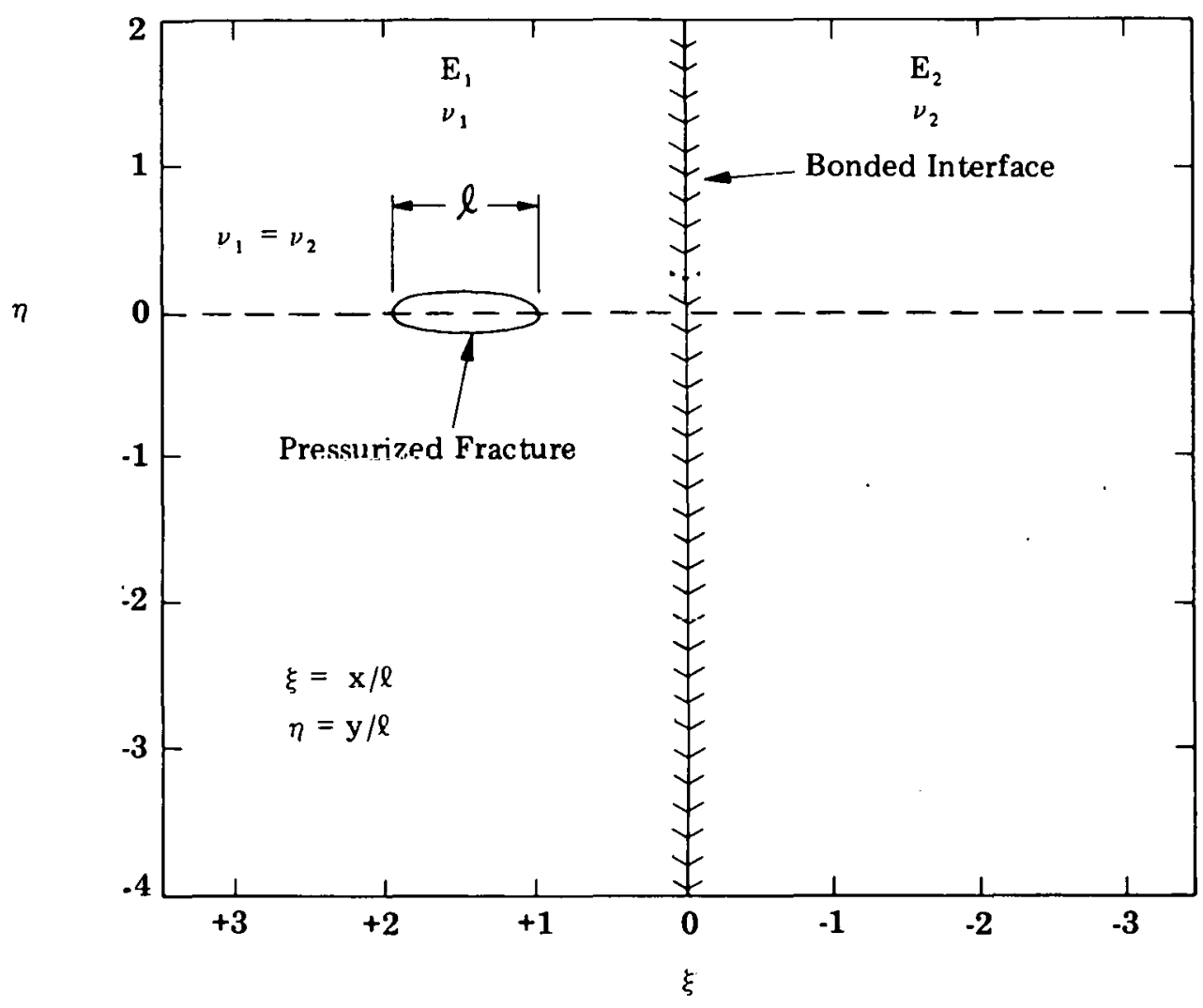

Figure 4-9 Geometry of Problems with Cracks Approaching Bonded Interface Between Two Materials Having Moduli. $E_{1}, \nu_{1}$ and $E_{2}, \nu_{2}$ 
Figures 4-10 and 4-11 show the maximum principal axis of strain resulting from a pressurized crack in the layered medium. One fracture tip is at $\xi=0.4$ from the interface for both figures. Figure 4-10 shows the case where the fracture is embedded in the lower modulus material. On Figure 4-11, the fracture is embedded in the higher modulus material. It illustrates that the change in material properties significantly effects the orientation of the principal strains, especially directly in front of the crack tip.

The strain normal to the interface and the shear strain along the interface for several positions of the crack with respect to the interface have been calculated and plotted. These strain values are computed in the coordinates of the interface. Since finite element techniques were used to calculate the elastic field, these strain values were computed on either side of the interface. Each curve on these plots is for one position, $\xi$, of the crack tip from the interface as a function of position $\eta$ along the interface (see Figure 4-9 for the geometry). Figures 4-12, 4-13, 4-14 and 4-15 display these normal and shear strain values for the case when $\mathrm{E}_{1}=10 \mathrm{GPa}$ and $\mathrm{E}_{2}=50 \mathrm{GPa}$. The pressure in the crack was $30 \mathrm{MPa}$. Figures 4-12 and 4-13 show the normal and shear strains just to the left of the interface while Figures 4-14 and 4-15 show similar strain functions just to the right of the interface. Observations show that the normal strains become more compressive as the fracture tip nears the interface. Also, as the fracture tip approaches the interface, the point of maximum compressive normal strain and maximum shear strain tends to approach the line $\eta=0$ (line extended from the fracture axis to the interface). The normal strain plots also indicate that the presence of the fracture tends to increase the normal strain at the interface directly ahead of the fracture tip. Also, as the tip approaches the interface, the normal strain at $\eta=0$ becomes more and more tensile. This could give rise to a reduction in the frictional stresses in this region.

For this case where the pressurized crack is in the lower modulus material, the resulting normal and shearing strains are larger on the lower modulus side of the interface than on the higher modulus side.

Figures 4-16 and 4-17 show similar strain values for the case where $\mathrm{E}_{1}=50 \mathrm{GPa}$ and $\mathrm{E}_{2}=10 \mathrm{GPa}$. In this case $\nu_{1}=\nu_{2}=0.25$. The pressure in the crack was $30 \mathrm{MPa}$. The normal and shear strain on these plots are computed in the interface coordinates. Figures 4-16 and 4-17 show the normal and shear strain along and just to the left of the interface while Figures 4-18 and 4-19 show similar strain functions along and just to the right of the interface (the geometry of the problems are shown on Figure 4-9). For this material configuration the general remarks discussed previously tend to be relevant, however, the normal strain becomes positive on the left of the interface directly ahead of the crack tip but remains compressive to the right of the interface in this region.

\subsubsection{Lens Calculations}

To determine the stress perturbations caused by the presence of lenses the following problems were analyzed with an LLL numerical model. Three geometries of lenses embedded in a homogeneous material are shown in Figures 4-20, 4-21 and 4-22. In each geometry Poisson's ratio for both materials is 0.35 and Young's modulus (E) for the lenses $(10 \mathrm{GPa})$ is half that of the surrounding material $(20 \mathrm{GPa})$ for the first calculation (Case 1). For the second calculation the Young's moduli were reversed (Case 2). A constant normal stress $\left(\sigma_{\mathrm{o}}\right)$ is applied in the negative $\mathrm{y}$ direction along $\mathrm{y}=0$. Since the distances and displacements in the problem will scale, the distances are given in terms of the 


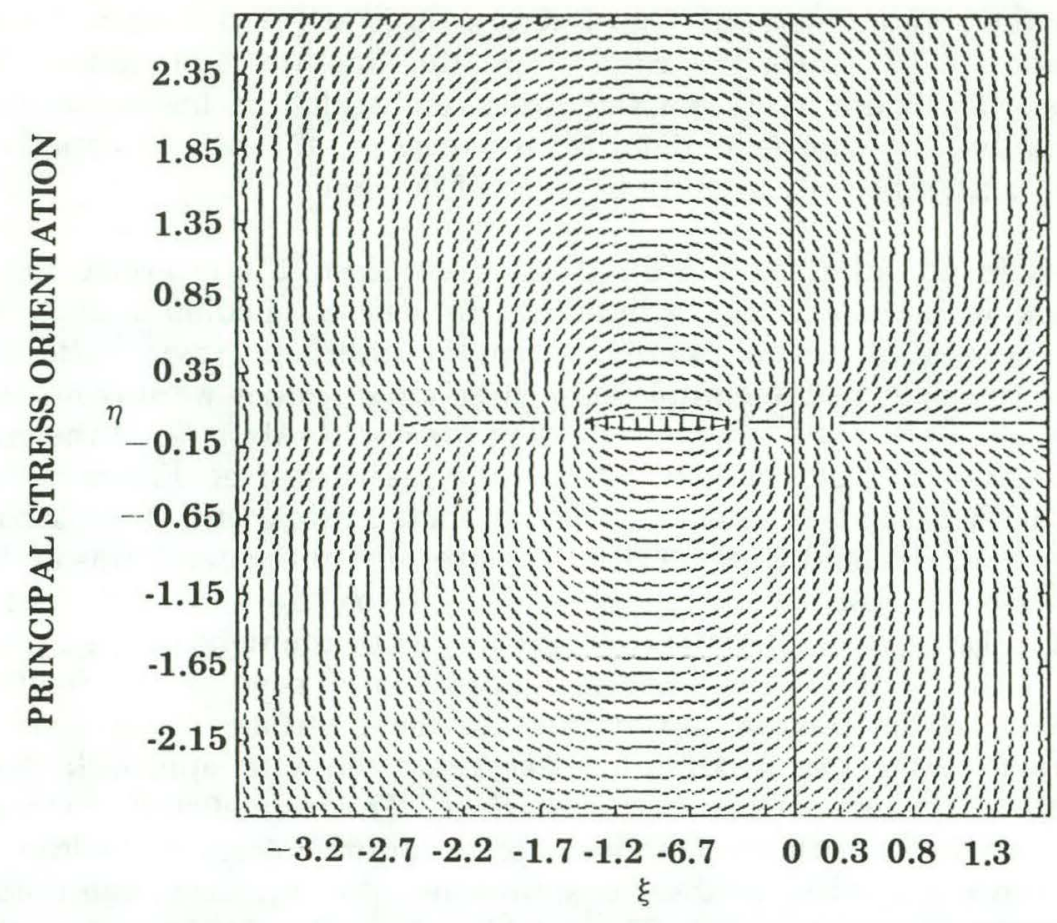

Figure 4-10 Axis of Maximum Principal Strain for the case $E_{1}=10 \mathrm{GPa}$ and $E_{2}=50 \mathrm{GPa}$. Interface is shown as Solid Line. Fracture is Schematically shown as ELLIPSE.

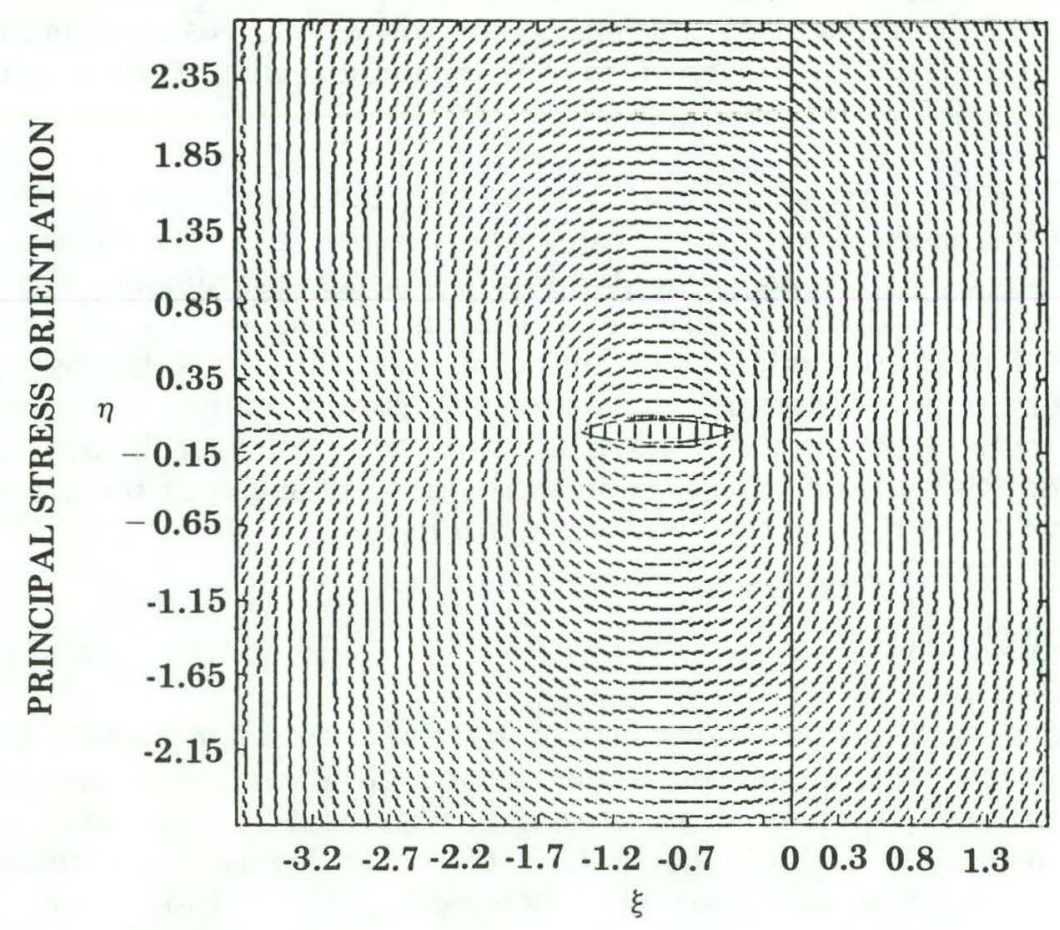

Figure 4-11 Axis of Maximum Principal Strain for the Case $E_{1}=50 \mathrm{GPa}$ and $E_{2}=10 \mathrm{GPa}$. Interface is shown as Solid Line. Fracture is Schematically shown as ELLIPSE. 


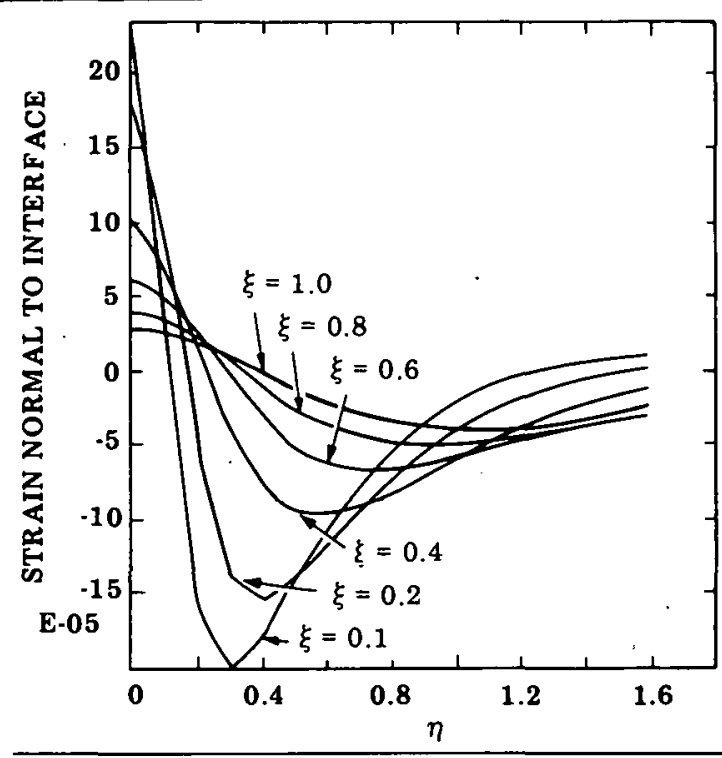

Figure 4-12 Normal Strain to Left of Interface as a Function of Distance Along the Interface for Various Distances of the Fracture Tip fron the Interface. $E_{1}=$ $10 \mathrm{GPa}$ and $E_{2}=50 \mathrm{GPa}$.

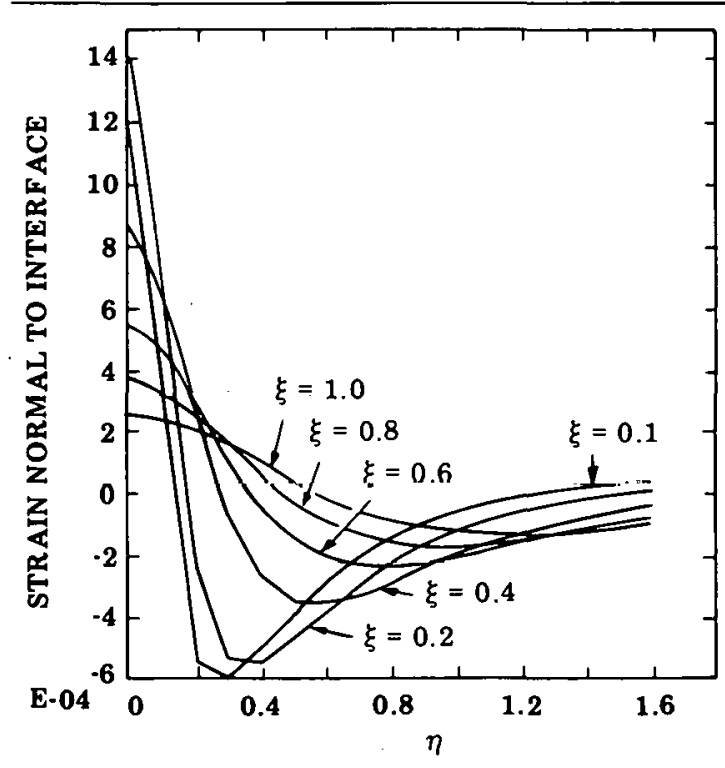

Figure 4-14 Normal Strain to Right of Interface as a Function of Distance Along the Interface for Various Distances of Fracture Tip from the Interface $E_{1}=10 \mathrm{GPa}$ and $E_{2}=50 \mathrm{GPa}$.

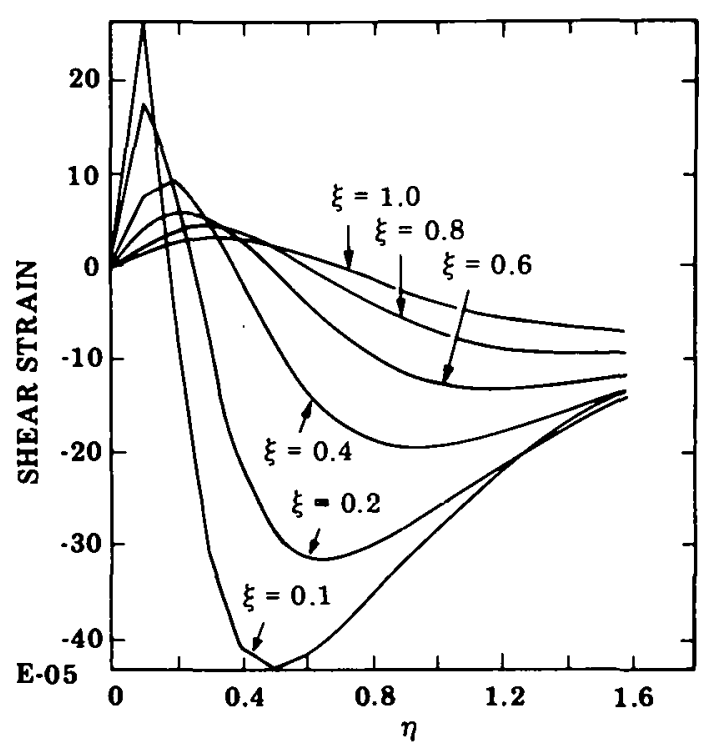

Figure 4-13 Shear Strain to Left of Interface for Various Distances of Fracture Tip from the Interface, $E_{1}=10 \mathrm{GPa}$ and $E_{2}=50 \mathrm{GPa}$

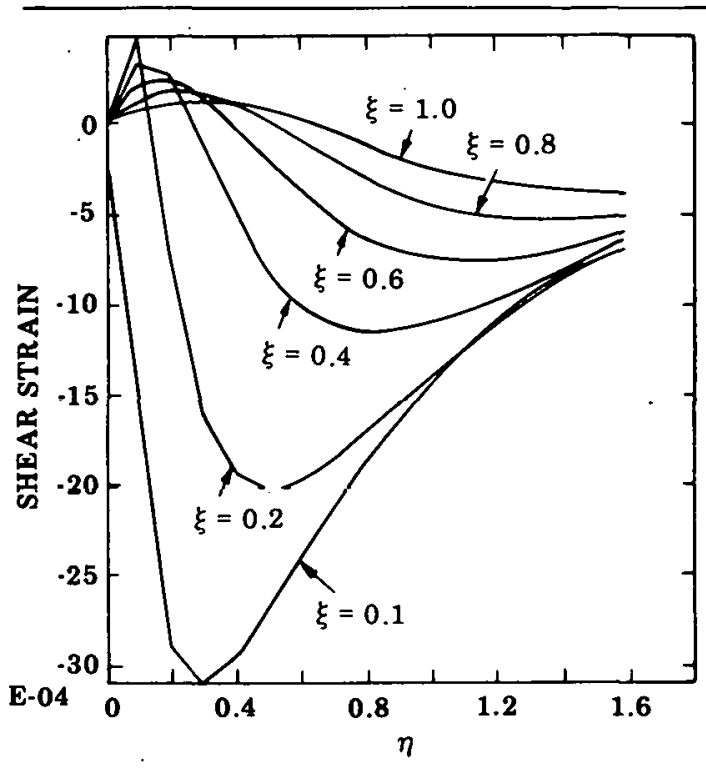

Figure 4-15 Shear Strain to the Right of Interface as a Function of Distance Along the Interface for Various Distances of Fracture Tip from the Interface. $E_{1}=10 \mathrm{GPa}$ and $E_{2}=$ $50 \mathrm{GPa}$. 


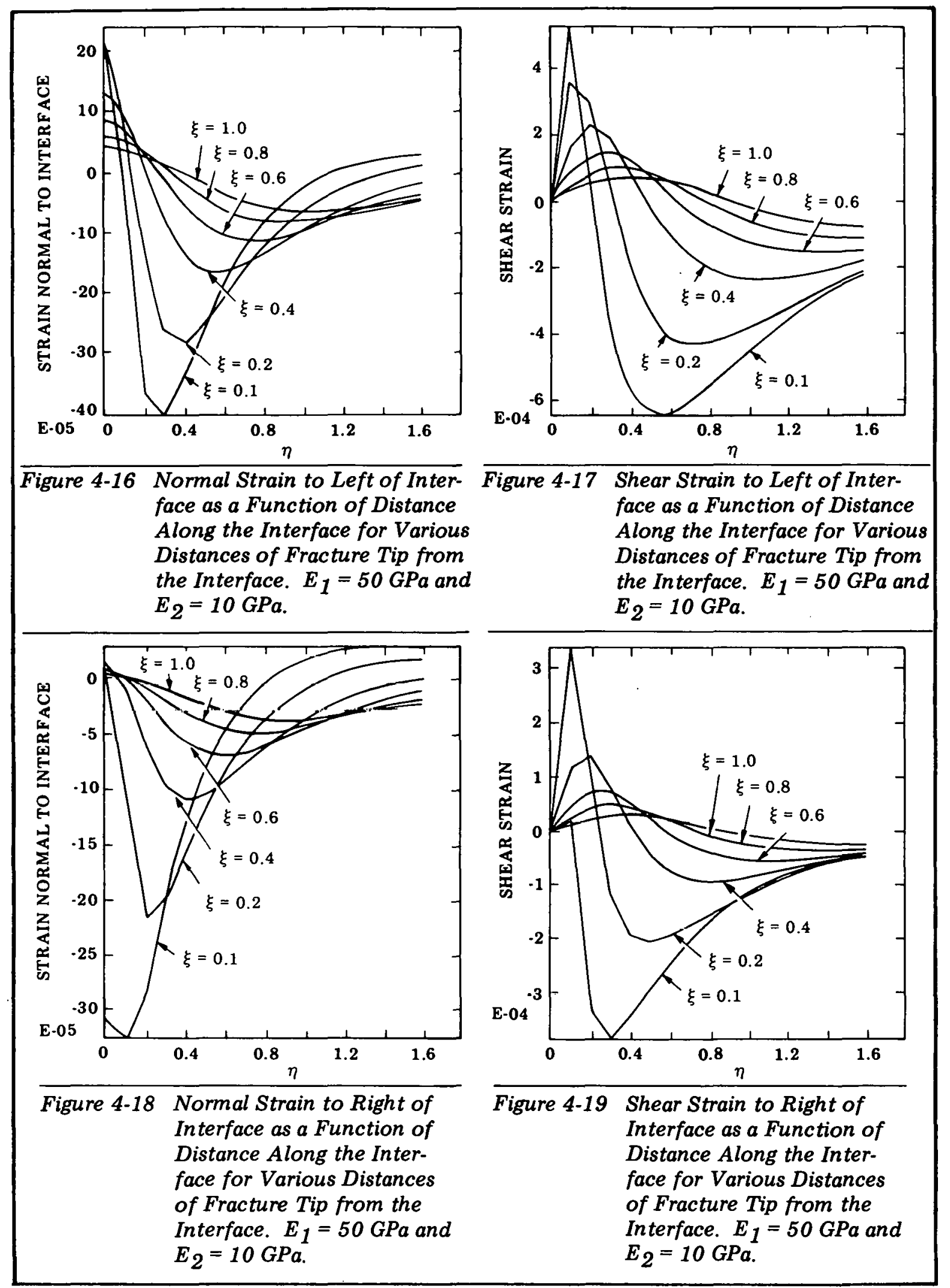




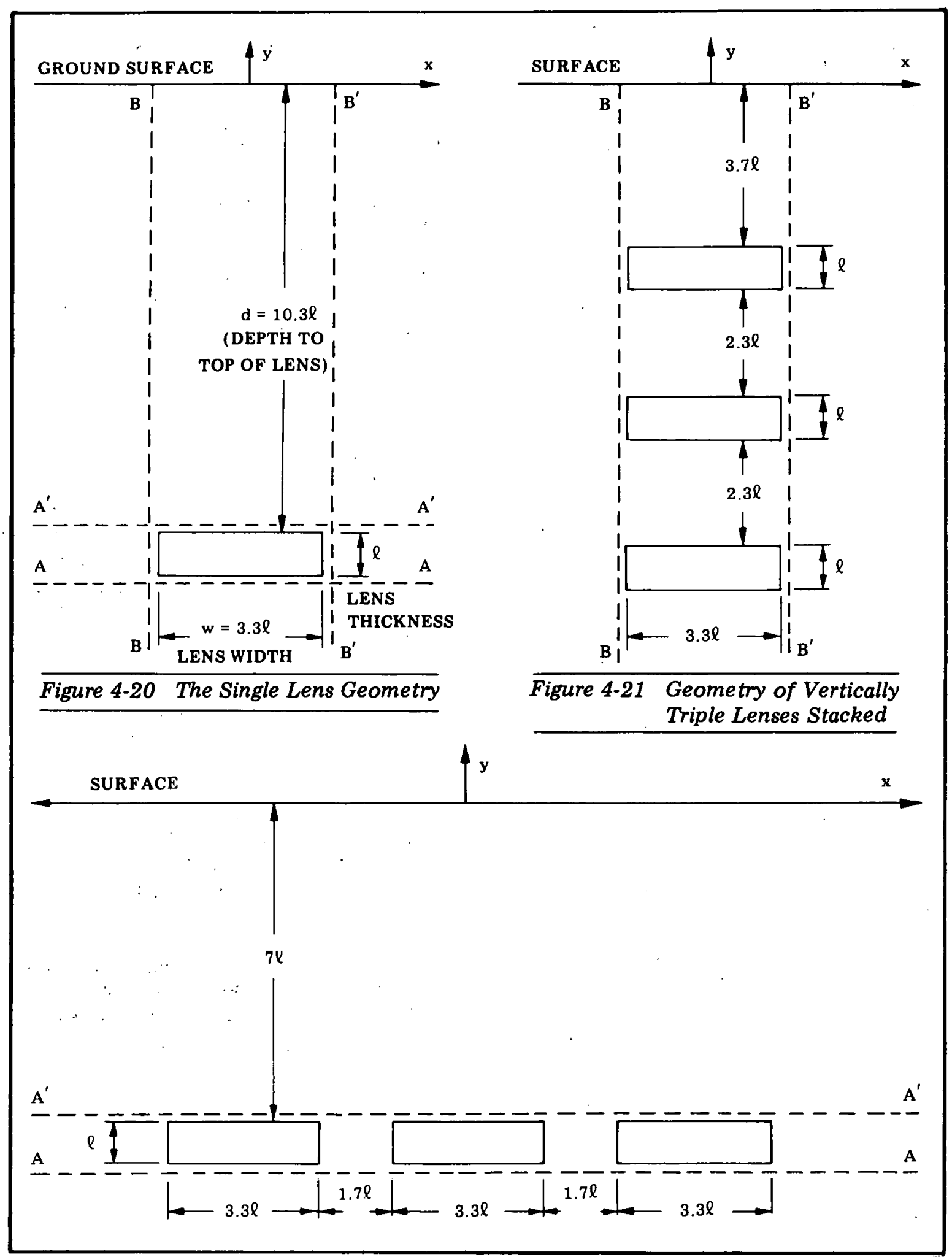

Figure 4-22 Geometry of Horizontally Arranged Triple Lenses 
lens thickness $\ell$. Two-dimensional plane strain is considered so that the lens and the material is assumed to extend infinitely in the $z$ direction. Furthermore, displacement in the $x$ direction at $x= \pm 40$ \& was not allowed.

The normal stress in the $y$ direction $\left(\sigma_{\mathrm{y}}\right)$ along the lines labeled $\mathrm{BB}$ and $\mathrm{B}^{\prime} \mathrm{B}^{\prime}$ in Figure 4-20 is shown in Figure 4-23 for Case $1\left(\mathrm{E}_{\text {lens }}=10 \mathrm{GPa}\right.$, elsewhere $\left.\mathrm{E}=20 \mathrm{GPa}\right)$. This calculation was reported in the status report of October 31,1978 . The stresses along the two lines are identical due to problem symmetry. Stress is nondimensionalized by dividing by the applied stress. Increasing $\sigma_{\mathrm{y}} / \sigma_{\mathrm{o}}$ corresponds to increasing compression. From Figure 4-23 compression is greatest along the lens and least about $2 \ell$ above and about $2 \ell$ below the lens. It would be expected that a horizontal fracture entering from outside the area of the lens would tend to cross line $\mathrm{BB}$ or $\mathrm{B}^{\prime} \mathrm{B}^{\prime}$ at one of these two points of least compression. Figure 4-24 is a plot of stress along $B B$ for the same single lens geometry with $E_{\text {lens }}=20$ $\mathrm{GPa}$ and elsewhere $\mathrm{E}=10 \mathrm{GPa}$ (Case 2). Here the least compression is right along the side of the lens. It is likely that a fracture approaching the lens would be drawn toward the lens for this case.

Figures 4-25 (Case 1) and 4-26 (Case 2) are plots of horizontal stress along the lines AA or $A^{\prime} A^{\prime}$ in Figure 4-20. Again, increasing stress corresponds to increasing compression. The stress along line $\mathrm{A}^{\prime} \mathrm{A}^{\prime}$ does not differ appreciably from the stress along AA. Inelastic deformation was not allowed in this analysis. Consequently, some of the severe character in the curve near the lens would be smoothed somewhat if plastic deformation occurred. In Figure 4-25 the least compression occurs above and below the center of the lens. One would expect a vertical hydrofracture to intersect the lens near its center for this case. In Figure 4-26 the least compression is about $2 \ell$ outside the extremities of the lens.

Figures 4-27 (Case 1 and 4-28 (Case 2) show vertical stress along the lines BB or $\mathrm{B}^{\prime} \mathrm{B}^{\prime}$ in Figure 4-21. In Figure 4-27 compression is greatest along the sides of the lenses. An approaching horizontal hydrofracture should tend to avoid the lens while for Case 2 (Figure 4-28) the fracture should be drawn to one of the lenses.

Figures 4-29 (Case 1) and 4-30 (Case 2) are plots of horizontal stress along the lines AA or $\mathrm{A}^{\prime} \mathrm{A}^{\prime}$ in Figure 4-22. Least compression in Figure 4-29 is above and below the center of the lenses while in Figure 4-30 least compression is between or outside the lenses. A vertical hydrofracture approaching the lenses should intersect the lenses for Case 1 and should avoid the lenses for Case 2.

When a lens has a larger modulus than the surrounding material, these analyses indicate that a horizontal fracture would be drawn toward the lens. Conversely, the stress field around the lens would tend to impede the growth of a vertical fracture toward the lens. The results of crack growth near interfaces must also be taken into account to determine whether the fracture will penetrate a lens.

\subsubsection{Experimental Program}

\subsubsection{Crack Growth Across Interfaces}

Last month LLL reported on experiments in which hydraulic fractures were driven across unbonded interfaces from dry Indiana limestone into water saturated Indiana limestone. 


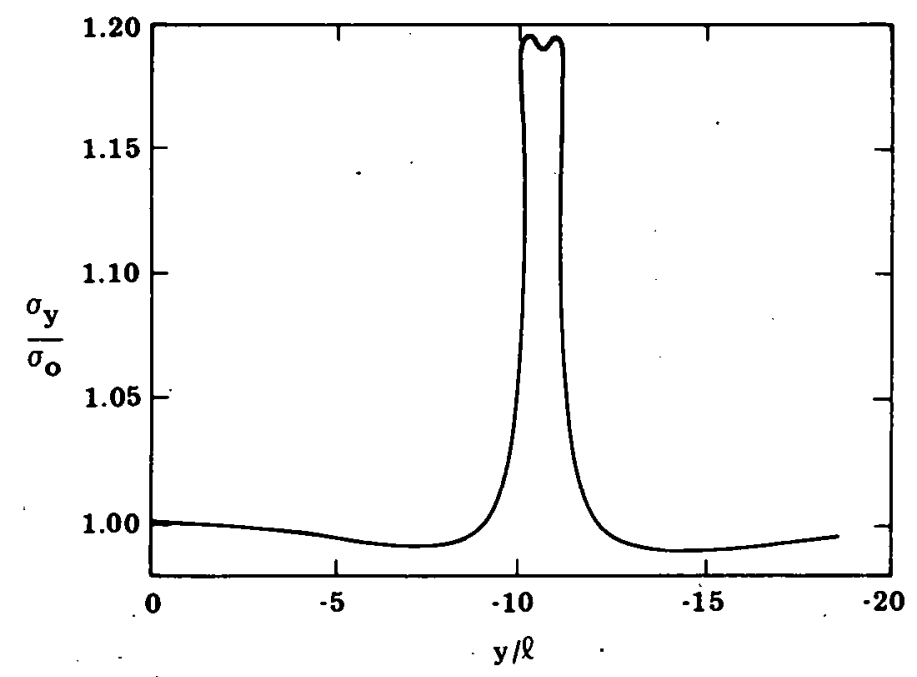

Figure 4-23 Normal Stress in the $y$ Direction Along the Lines $B B$ or $B^{\prime} B^{\prime}$ in Figure 4-20. Increasing Stress Corresponds to Increasing Compression. For Case 1: Young's Modulus in the Lens is $10 \mathrm{GPa}$; Young's Modulus of the Surrounding Material is $20 \mathrm{GPa}$.

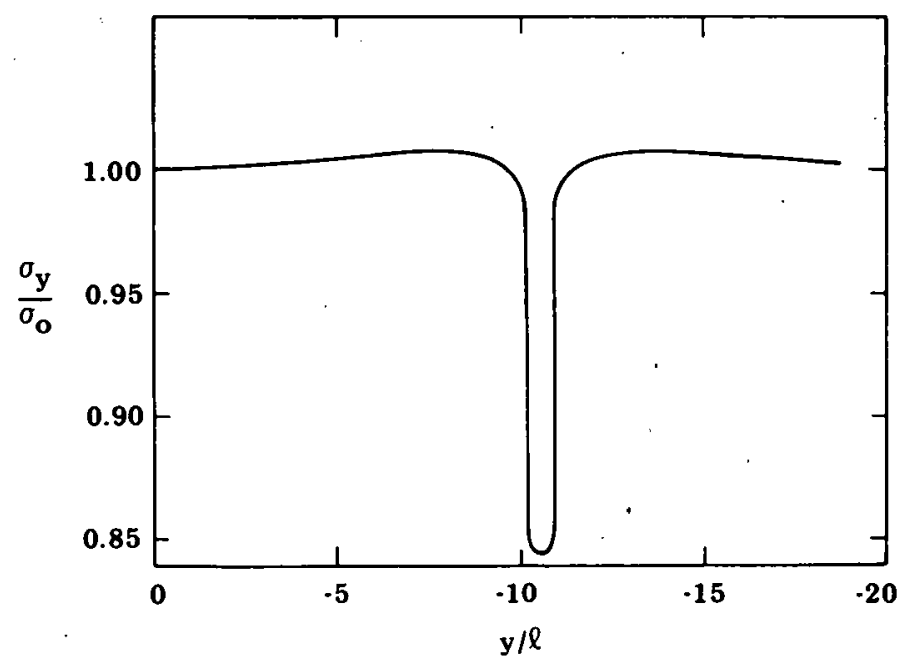

Figure 4-24 Normal Stress in the y Direction Along the Lines $B B$ and $B^{\prime} B^{\prime}$ in Figure 4-20. Increasing Stress Corresponds to Increasing Compression. For Caso 3: $E_{l e l \iota s}=20$ r.Pa and elsewhere $E=10 \mathrm{GPa}$. 


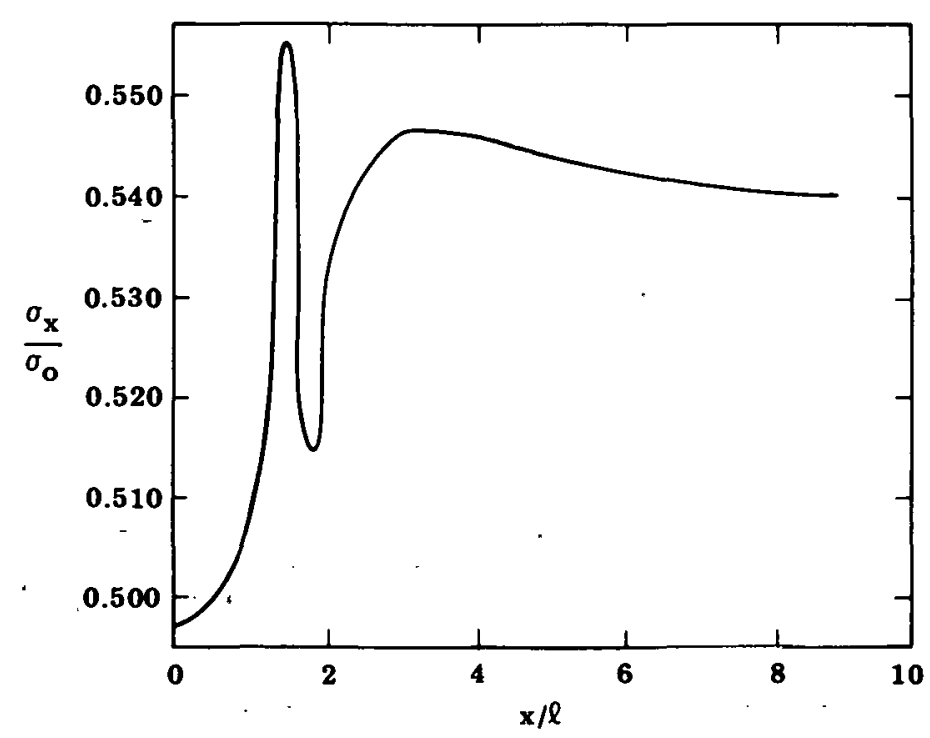

Figure 4-25 Normal Stress in the $x$ Direction Along the Lines $A A$ or $A^{\prime} A^{\prime}$ in Figure 4-20 for Case 1. Increasing Stress Corresponds to Increasing Compression.

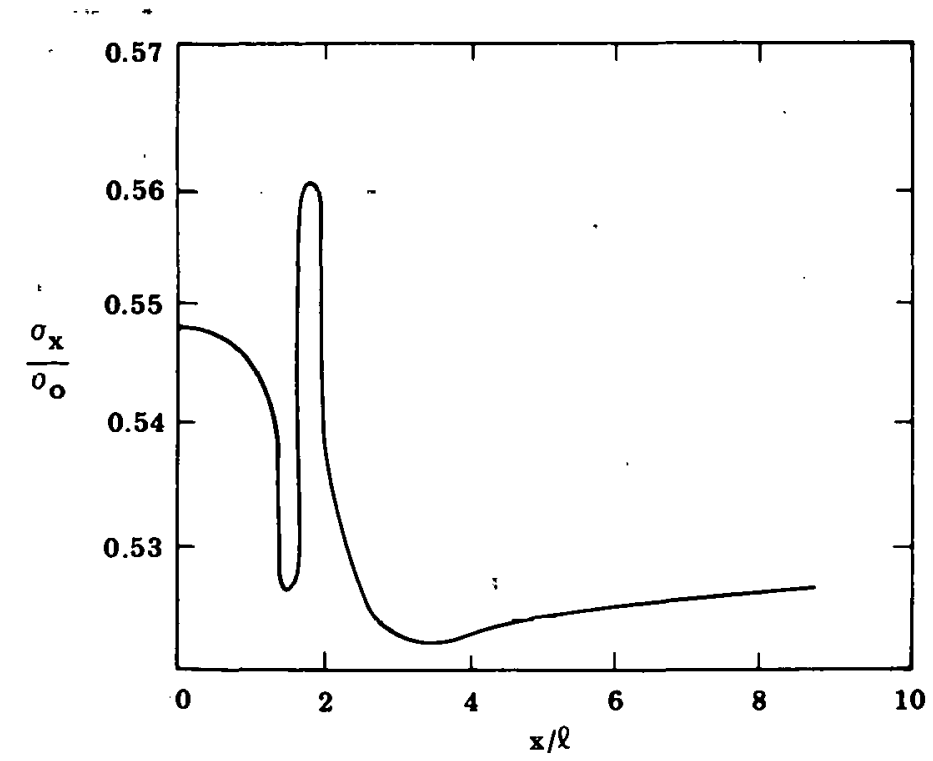

Figure 4-26 Normal Stress in the $x$ Direction Along the Lines $A A$ or $A^{\prime} A^{\prime}$ in Figure 4-20 for Case 2. 


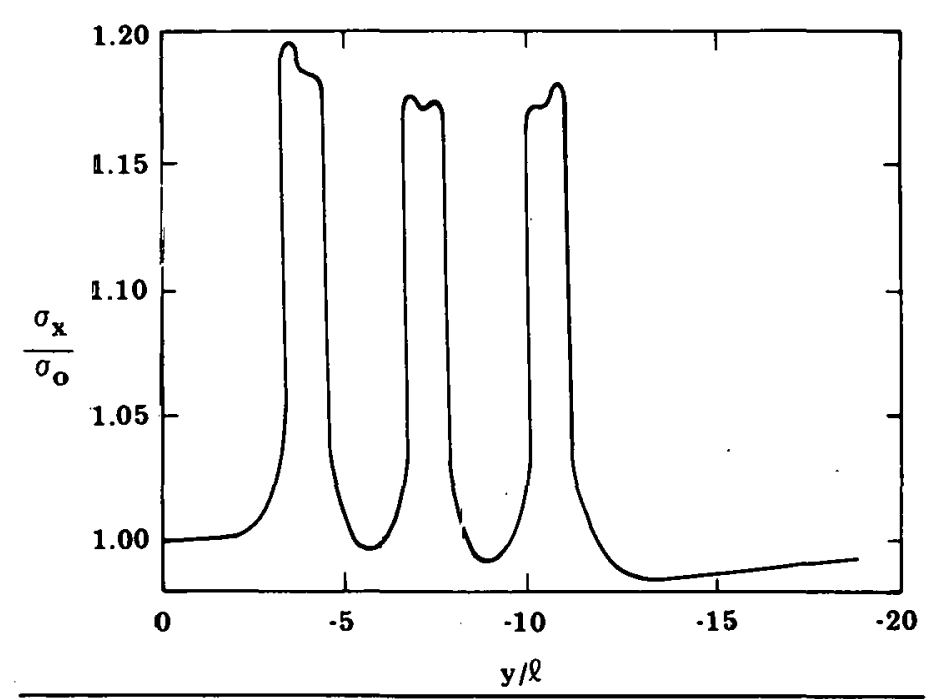

Figure 4-27 Normal Stress in the $y$ Direction Along the Lines $B B$ or $B^{\prime} B^{\prime}$ in Figure 4-21 for Case 1

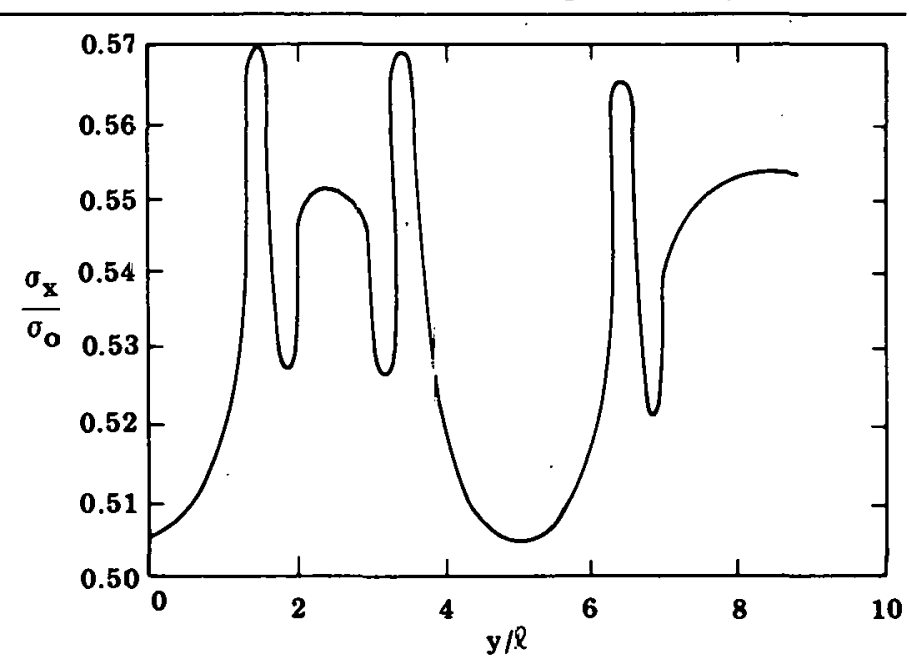

Figure 4-29 Normal Stress in the $x$ Direction for Lines $A A$ or $A^{\prime} A^{\prime}$ in Figure 4-22 for Case 1

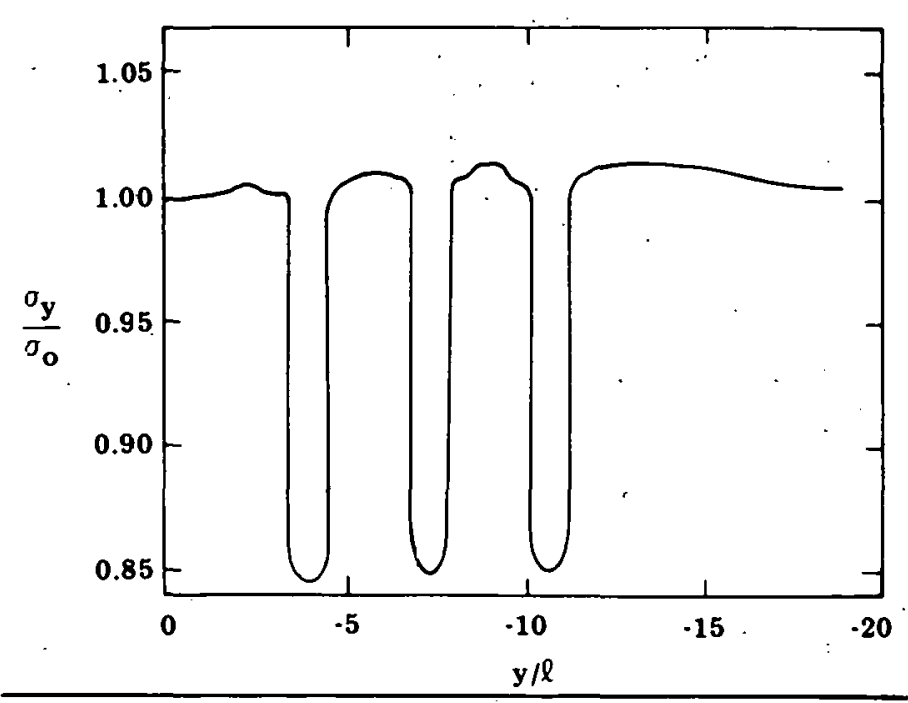

Figure 4-28 Normal Stress in the $y$ Direction Along the Lines $B B$ or $B^{\prime} B^{A}$ in Figure 4-21 for Case 2

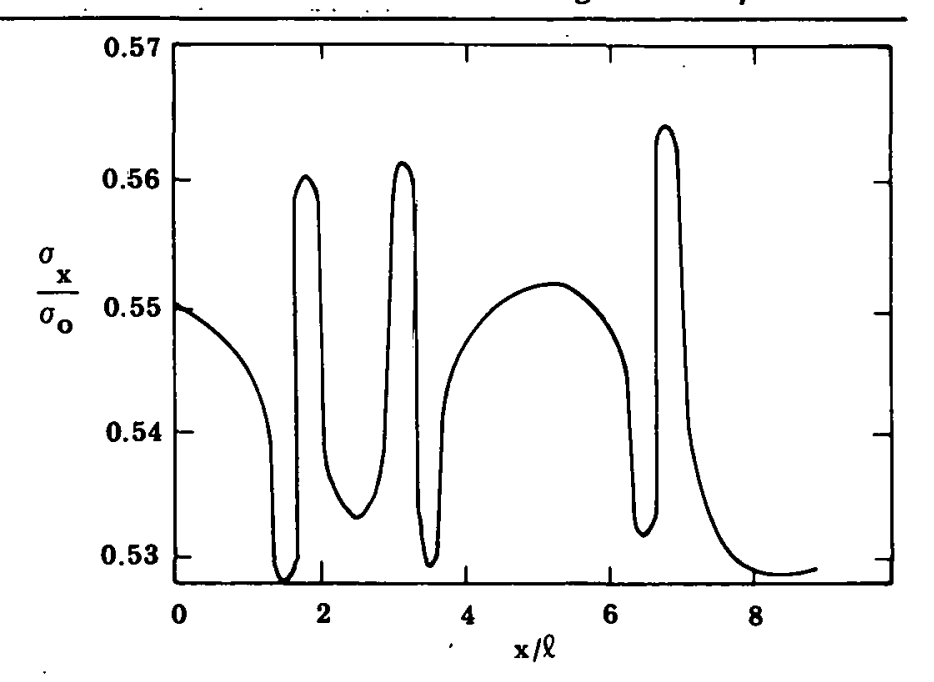

Figure 4-30 Normal Stress in the $x$ Direction for Lines $A A$ or $A^{\prime} A^{\prime}$ in Figure 4-22 for Case 2 
It was found that the threshold stress load across the interface for cracks to cross was lowered from about $650 \mathrm{psi}$ to about $500 \mathrm{psi}$ by saturation. The effect of the water in the interface might be expected to be that of a lubricant which would reduce the shear or frictional force transmitted across the interface at a given normal load. Such an effect would make it more difficult to grow a crack across that interface. The result that the crack will cross into the saturated material at a lower normal load across the interface suggests that the material properties of the saturated material which govern its acceptance of a crack may be sufficiently altered so that they more than compensate for the lubrication effect of the water. Since tensile strength is felt to be one of the important material properties, Brazil tests were performed to measure the tensile strength of the saturated limestone. The results indicated a tensile strength of $19 \pm 3$ bars as compared to about 50 bars for dry limestone. This dramatic decrease in tensile strength may account for the lowering of the threshold stress for cracks to cross the interface.

\subsubsection{Rock Properties}

During the month of October, design was completed for a hot-gas permeability apparatus for rock specimens at pressures up to $50 \mathrm{MPa}$ and temperatures up to $250^{\circ} \mathrm{C}$. Most apparatus parts have been ordered. Design has also been completed for a high pressure vessel for measuring ultrasonic velocities in six directions on one rock specimen. This vessel is being constructed. With this vessel the elastic constant tensor of a transversely isotropic rock as a function of confining pressure up to $1.0 \mathrm{GPa}$ can be determined. This vessel can be easily altered for moderate temperature operation if such measurements are desired.

\subsubsection{Related WGSP Activities}

On Ootobor 11 and 12 LLL allended a meeting at Sandia Laboratories in Albuquerque to discuss mineback work on the interface experiments being conducted at the Nevada Test Site. On October 24, LLL attended a meeting held at CER Corporation in Las Vegas to help formulate the logging program for the WGSP.

\subsubsection{Schedule Status}

Figure 4-31 is a milestone chart of LLL FY 1979 activities.

\subsection{SANDIA LABORATORIES}

\subsubsection{EGR Instrumentation and Diagnostic Program}

\subsubsection{Hydraulic Fracture Characterization}

Sandia will begin participation in a follow-on set of experiments in the AMOCO Wattenberg Field, north of Denver, beginning the week of November 6. A series of three gas wells are planned in the Muddy " $J$ " Sands, approximately 8,000 ft deep. 


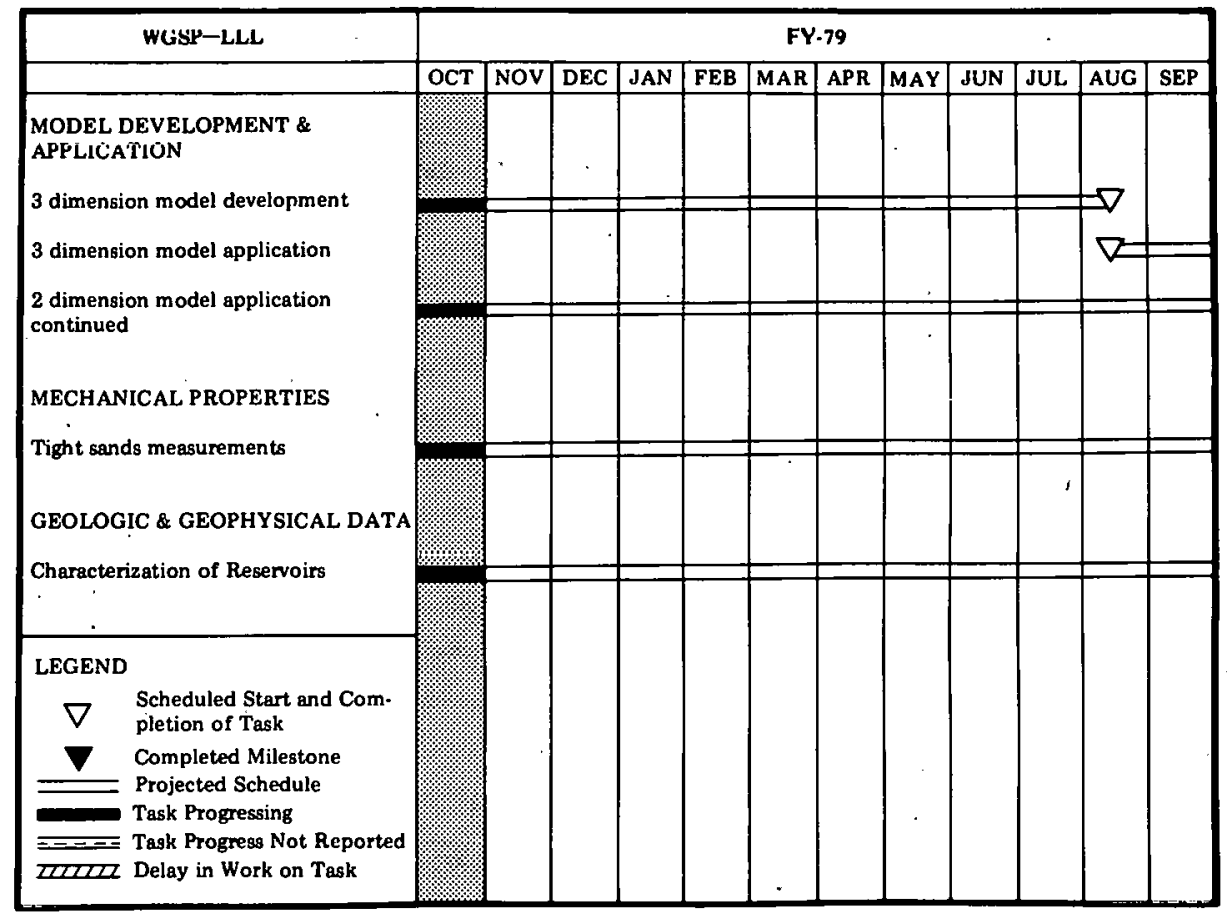

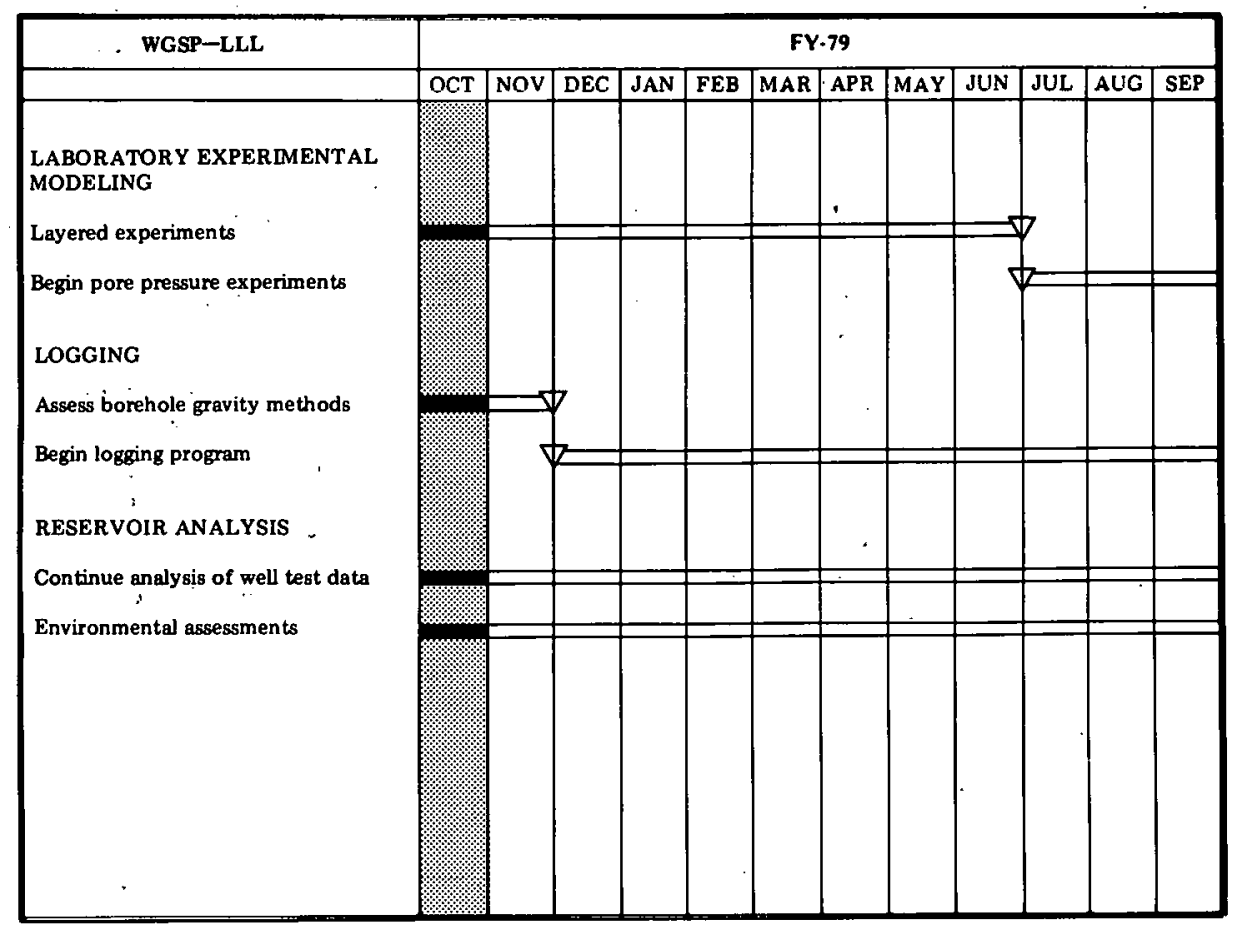

Figure 4-31 Milestone Chart-LLLL 
A breakdown procedure experiment is planned for all three wells. Sandia's instrumentation is to include the downhole three axis wallclamp geophone and the HP high resolution recording pressure gauge. The geophone has been instrumented with high temperature geophones in preparation for the high formation temperature.

Present planning calls for the Surface Electrical Potential System (SEPS) to be installed on the first and third wells during the full fracture experiment. Residential congestion around well No. 2 makes the installation of the SEPS impractical. Additional instrumentation during the full fracture will include the HP recording pressure gauge and the surface tiltmeter. Fracture fluid pressure and flow data from the service company transducer will also be recorded by SEPS instrumentation.

The first well for the SEPS installation will be Gorden Turkey Farm D-1. This well has a depth of $7,972 \mathrm{ft}$ and is uncased at the fracture interface. Current from the SEPS will be injected at this level via the downhole current probe. Previous attempts at this procedure have resulted in current pulser failure. Hardware checkout at this point indicates that this problem has been corrected. The surface electrical potential will be recorded at radii of 1,200 and 2,400 ft. Two current sink wells, approximately 90 degrees apart, will be used.

\subsubsection{Advanced Borehole Logging Program}

Sandia attended the Western Gas Sands Logging Program meeting held at CER Corporation offices in Las Vegas. The meeting's objective was to bring together participants in the Logging Program to develop a working plan for geophysical logging research and development as regards tight western gas sand reservoirs.

The Sandia program concerns three areas; nuclear magnetic resonance (NMR), electromagnetic theory (EM), and borehole neutronics. These three areas were developed as a direct output of investigations carried out by a Sandia Logging Task Force whose conclusions are summarized in the following section. The NMR aspect of Sandia's program will involve evaluation of the applications of NMR techniques to low-permeability formations through laboratory testing and development of empirical relationships. Advanced instrument development for NMR measurements is part of the program given by Los Alamos Scientific Laboratories. The electromagnetic theory program involves development of the physical theory of time-dependent, borehole EM response of geologic formations leading to a series of laboratory measurements and, ultimately, tool development. The Sandia contribution to the overall borehole neutronic effort will be in the areas of new tube development and spectral gamma analysis.

\subsubsection{Conclusions of Sandia Logging Task Force}

A logging task force formed in February, 1978, was chartered to investigate the stateof-the-art in commercial geophysical logs as well as logging research to determine which areas of concentration might be most beneficial to natural gas reservoir applications. Numerous months of literature search, theory development, and interviews with production and research personnel from the petroleum industry, academic community, and logging service organizations, indicated that the areas of NMR and electromagnetics would provide 
most benefit. In addition, continued research and development of existing Sandia borehole neutronics programs is encouraged with petroleum applications in mind. A working relationship with Chevron Oil Field Research Laboratories for NMR study of western gas sand formations has been developed, and a program for developing the pertinent electromagnetic theory linked to lab measurements has been initiated. These developments form the basis for the Sandia program described in the previous section.

\subsubsection{Other Program Activities}

David A Northrop met with Dr. Phil Randolph and Dr. Leo Rogers of the Institute of Gas Technology in Chicago on October 19, 1978. The purpose of the meeting was to examine IGT data on in situ stress variations (to be compared with those observed at NTS) and to explore IGT participation in program activities.

Carl L. Schuster presented a paper titled Detection Within the Wellbore of Seismic Signals Created by Hydraulic Fracturing (SPE 7448) at the 53rd Annual SPE Technical Conference. The abstract of this paper appears in Section 2.2.2, "Articles and Publications" of this report.

Mr. Schuster also presented a paper titled An Overview of the Electrical Potential Method for Determing Fracture Orientation at the 1978 Annual ASCE Meeting.

\subsubsection{Schedule Status}

Figure 4-32 is a milestone chart of the FY 1979 Sandia activities.

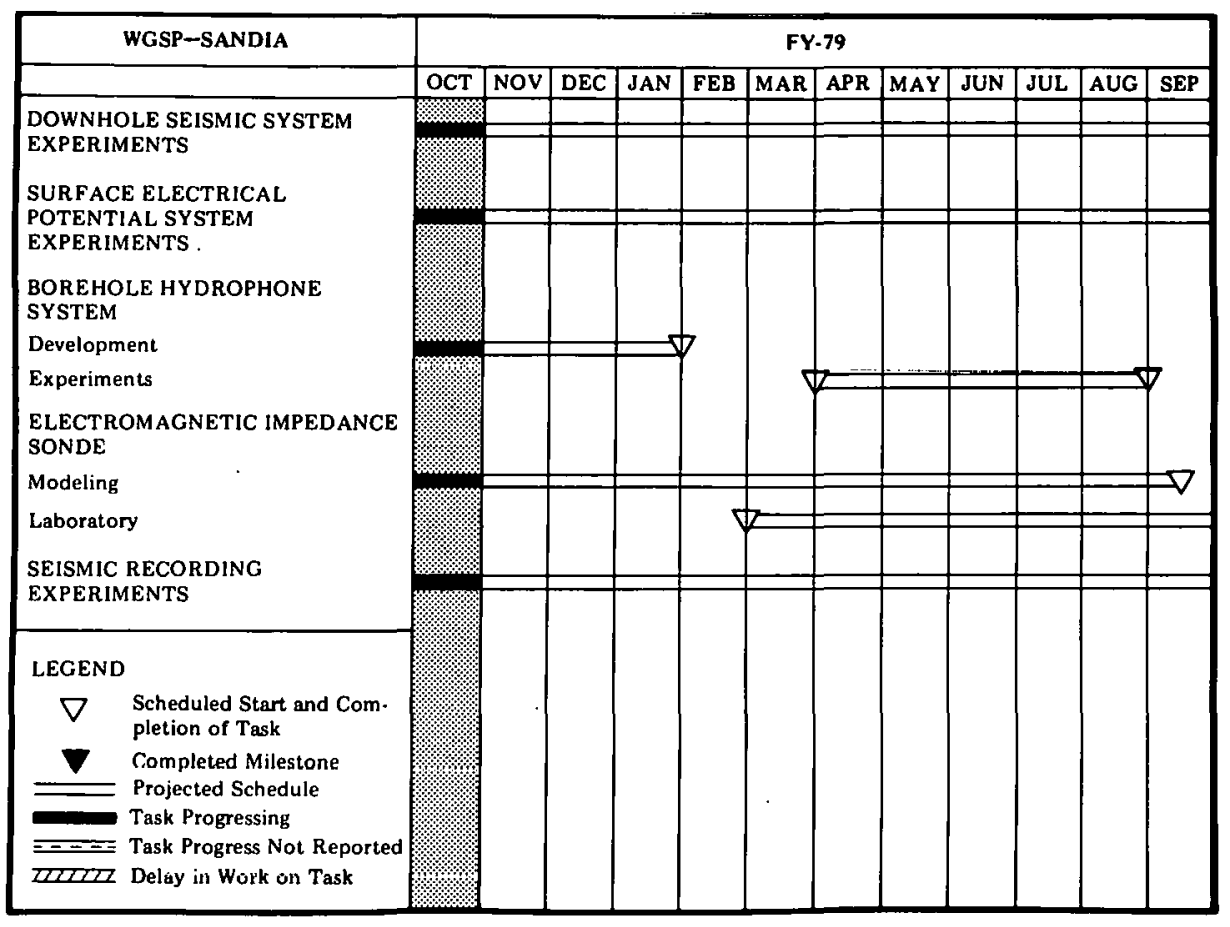

Figure 4-32 Milestone Chart-Sandia 
THIS PAGE

\section{WAS INTENTIONALLY \\ LEFT BLANK}




\section{FIELD TESTS AND DEMONSTRATIONS}

\subsection{BACKGROUND}

Specific field tests are essential to verify the findings of laboratory tests and modeling studies. The field test and demonstration program involves cooperation between industry and government and also interacts geologic studies with laboratory research and development. The following projects are in an active status in the WGSP:

- A dry gas injection experiment in the Wattenberg Field, Colorado, by Colorado Interstate Gas Company,

- MHF demonstrations by Gas Producing Enterprises in the Uinta Basin, Utah,

- MHF treatment of the Cotton Valley Limestone Formation in Limestone County, Texas, by Mitchell Energy Corporation,

- MHF demonstrations in the Piceance Basin, Colorado, by Mobil Research and Development Corporation and Rio Blanco Natural Gas Company, and

- A mineback testing program by Sandia Laboratories.

The CER Corporation RB-MHF 3 is on an inactive status pending satisfactory contractual arrangements to perform additional tests, and for final disposition of the well.

Table 5-1 summarizes both completed and active WGSP MHF treatments. Progress of these ongoing projects is presented in the following sections. 
Table 5-1 MHF Contract Locations and Frac Data

\begin{tabular}{|c|c|c|c|c|c|c|}
\hline COMPANY, BASIN & $\begin{array}{l}\text { LOCATION } \\
\text { T/R / Sec }\end{array}$ & WELL & $\begin{array}{c}\text { INTERVAL } \\
\text { FRACTURED } \\
\text { Feet }\end{array}$ & $\begin{array}{l}\text { FRAC. } \\
\text { DATE }\end{array}$ & $\begin{array}{l}\text { FRAC. } \\
\text { TREATMENT } \\
\text { Lbs of Sand }\end{array}$ & $\begin{array}{l}\text { FLUID } \\
\text { INJECTED } \\
10^{3} \mathrm{Gal}\end{array}$ \\
\hline $\begin{array}{l}\text { AUSTRAL } \\
\text { Piceance, } \\
\text { Mesaverde } \\
\end{array}$ & $\begin{array}{l}7 \mathrm{~S}, 94 \mathrm{~W}, \mathrm{S3} \\
\text { Garfield Co. } \\
\text { Colorado } \\
\end{array}$ & $\begin{array}{l}\text { Federal } \\
3-94\end{array}$ & $5,170 \cdot 6,333$ & $8-25-76$ & $1,140,000$ & $\begin{array}{l}542 \mathrm{Gel} \\
\text { Gel H O }\end{array}$ \\
\hline $\begin{array}{l}\text { CONSORTIUM } \\
\text { MANAGED BY } \\
\text { CER CORPORATION } \\
\text { Piceance, Mesaverde } \\
\end{array}$ & $\begin{array}{l}\text { 3S, } 98 \mathrm{~W}, \mathrm{S1} 1 \\
\text { Rio Blanco Co. } \\
\text { Colorado }\end{array}$ & RB-MHF-3 & $\begin{array}{l}8,048-8,078 \\
7,760 \cdot 7,864 \\
5,925 \cdot 6,016 \\
5,851 \cdot 5,869 \\
\end{array}$ & $\begin{array}{r}10 \cdot 23 \cdot 74 \\
5-2-75 \\
5 \cdot 4 \cdot 76 \\
11 \cdot 3 \cdot 76 \\
\end{array}$ & $\begin{array}{l}400,000 \\
880,000 \\
815,000 \\
448,000 \\
\end{array}$ & $\begin{array}{l}117 \mathrm{Gel} \\
285 \mathrm{Gel} \\
400 \mathrm{Gel} \\
228 \mathrm{Gel}\end{array}$ \\
\hline \multirow{8}{*}{$\begin{array}{l}\text { GAS PRODUCING } \\
\text { ENTERPRISES, INC. } \\
\text { Uinta, } \\
\text { Wasatch and } \\
\text { Mesaverde }\end{array}$} & $\begin{array}{l}\text { 10S, 22E, S10 } \\
\text { Uintah County } \\
\text { Utah }\end{array}$ & $\begin{array}{l}\text { Natural } \\
\text { Buttes } \\
\text { No. } 18\end{array}$ & $6,490 \cdot 8,952$ & $9 \cdot 22 \cdot 76$ & $1,480,000$ & $745 \mathrm{Gel}$ \\
\hline & $\begin{array}{l}\text { 10S, } 21 E, S 21 \\
\text { Uintah County } \\
\text { Utah }\end{array}$ & $\begin{array}{l}\text { Natural } \\
\text { Buttes } \\
\text { No. } 19\end{array}$ & $\begin{array}{l}8,900-9,664 \\
7 ; 224-8,676\end{array}$ & $\begin{array}{l}9 \cdot 21-76 \\
9 \cdot 28 \cdot 76\end{array}$ & $\begin{array}{l}424,000 \\
784,000\end{array}$ & $\begin{array}{l}280 \mathrm{Gel} \\
364 \mathrm{Gel}\end{array}$ \\
\hline & $\begin{array}{l}9 \mathrm{~S}, 21 \mathrm{E}, \mathrm{S} 22 \\
\text { Uintah County } \\
\text { Utah }\end{array}$ & $\begin{array}{l}\text { Natural } \\
\text { Buttes } \\
\text { No. } 14\end{array}$ & $6,646 \cdot 8,004$ & $3-15-77$ & $1,098,000$ & $544 \mathrm{Oel}$ \\
\hline & $\begin{array}{l}\text { 9S, 21E, S28 } \\
\text { Uintah County } \\
\text { Utah }\end{array}$ & $\begin{array}{l}\text { Natural } \\
\text { Buttes } \\
\text { No. } 20\end{array}$ & $8,498-9,476$ & $6-22-77$ & 826,000 & $322 \mathrm{Gel}$ \\
\hline & $\begin{array}{l}\text { 10S, 22E, S18 } \\
\text { Uintah County } \\
\text { Utah }\end{array}$ & $\begin{array}{l}\text { Natural } \\
\text { Byttes } \\
\text { No. } 22\end{array}$ & $6,858-8,550$ & $11-21-77$ & $1,091,000$ & 479 Gel \\
\hline & $\begin{array}{l}\text { 9S, 21E, S19 } \\
\text { Uintah County } \\
\text { Utah }\end{array}$ & $\begin{array}{l}\text { Natural } \\
\text { Buttes } \\
\text { No. } 9\end{array}$ & $5,661 \cdot 8,934$ & $3 \cdot 27 \cdot 78$ & 554,000 & $349 \mathrm{Gel}$ \\
\hline & $\begin{array}{l}\text { 10S, } 21 E, S 29 \\
\text { Uintah County } \\
\text { Utah }\end{array}$ & $\begin{array}{l}\text { Natural } \\
\text { Buttes } \\
\text { No. } 2\end{array}$ & $7,251-8,774$ & 8- $8-78$ & $1,965,000$ & $722 \mathrm{Gel}$ \\
\hline & $\begin{array}{l}\text { 10S, 22E. S7 } \\
\text { Uintah County } \\
\text { Ittah }\end{array}$ & $\begin{array}{l}\text { Natural. } \\
\text { Buttes } \\
\text { Mo, Q3 } \\
\end{array}$ & $5,080 \cdot 6,294$ & $10 \cdot 4 \cdot 78$ & 440,000 & $240 \mathrm{Gel}$ \\
\hline $\begin{array}{l}\text { DALLAS PRODUCTION } \\
\text { Fort Worth, } \\
\text { Bend Cong. }\end{array}$ & $\begin{array}{l}\text { Ben D. Smith } \\
\text { Survey A.779 } \\
\text { Wise County } \\
\text { Texas } \\
\end{array}$ & $\begin{array}{l}\text { Ferguson } \\
\text { A-1 }\end{array}$ & $5,957 \cdot 6,794$ & $9-10-76$ & 506,000 & $\begin{array}{l}139 \text { Foam } \\
198 \text { Emul }\end{array}$ \\
\hline $\begin{array}{l}\text { EL PASO NATL: GAS } \\
\text { Northern Green } \\
\text { Kiver, } \\
\text { Fort Union } \\
\end{array}$ & $\begin{array}{l}30 \mathrm{~N}, 108 \mathrm{~W}, \text { S5 } \\
\text { Sublette Co. } \\
\text { Wyoming }\end{array}$ & $\begin{array}{l}\text { Pinedale } \\
\text { Ifinit } \\
\text { No. } 5\end{array}$ & $\begin{array}{l}10,950-11,180 \\
10,120-10,790\end{array}$ & $\begin{array}{r}7 \cdot 2 \cdot 75 \\
10-20-75\end{array}$ & $\begin{array}{r}518,000 \\
1,422,000\end{array}$ & $\begin{array}{l}183 \mathrm{Emul} \\
8 \mathrm{Gel} \\
459 \mathrm{Gel}\end{array}$ \\
\hline $\begin{array}{l}\text { MOBIL } \\
\text { Piceance, } \\
\text { Mesaverde }\end{array}$ & $\begin{array}{l}2 \mathrm{~S}, 97 \mathrm{~W}, \mathrm{~S} 13 \\
\text { Rio Blanco Co. } \\
\text { Colorado }\end{array}$ & F-31-13G & $\begin{array}{r}10,549-10,680 \\
9,432-9,538 \\
8,163 \cdot 8,650 \\
7,704-7,794\end{array}$ & $\begin{array}{l}6 \cdot 22 \cdot 77 \\
8 \cdot 24-77 \\
7 \cdot 6 \cdot 78 \\
9 \cdot-7-78\end{array}$ & $\begin{array}{l}580,000 \\
600,000 \\
660,000 \\
218,000\end{array}$ & $\begin{array}{l}316 \mathrm{Gel} \\
260 \mathrm{Gel} \\
288 \mathrm{Gel} \\
120 \mathrm{Gel}\end{array}$ \\
\hline $\begin{array}{l}\text { PACIFIC } \\
\text { TRANSMISSION } \\
\text { Uinta, Mesaverde }\end{array}$ & $\begin{array}{l}8 \mathrm{~S}, 23 \mathrm{E}, \mathrm{S} 25 \\
\text { Uintah County }\end{array}$ & $\begin{array}{l}\text { Federal } \\
23-25\end{array}$ & NO FRAC & RFORMED & & \\
\hline $\begin{array}{l}\text { RIO BLANCO NATL. GAS } \\
\text { Piceance, } \\
\text { Mesaverde }\end{array}$ & $\begin{array}{l}4 S, 98 W, S 4 \\
\text { Rio Blanco Co. } \\
\text { Colorado }\end{array}$ & $\begin{array}{l}\text { Federal } \\
498 \cdot 4 \cdot 1\end{array}$ & $\begin{array}{l}6,150-6,312 \\
5,376-5,960\end{array}$ & $\begin{array}{l}10-22-76 \\
11-30-77\end{array}$ & $\begin{array}{l}766,000 \\
243,000+ \\
22,500 \text { Beads } \\
\end{array}$ & $\begin{array}{r}276 \mathrm{Gel} \\
164 \mathrm{Gel} \\
\end{array}$ \\
\hline $\begin{array}{l}\text { WESTCO } \\
\text { Uinta, } \\
\text { Mesaverde }\end{array}$ & $\begin{array}{l}\text { 1OS, } 19 \mathrm{E}, \mathrm{S} 34 \\
\text { Uintah County }\end{array}$ & $\begin{array}{l}\text { Home Fed. } \\
\text { No. } 1\end{array}$ & $\begin{array}{r}7,826-9,437 \\
10,014 \cdot 10,202\end{array}$ & $\begin{array}{l}12-21-76 \\
10 \cdot 1 \cdot 76\end{array}$ & $\begin{array}{l}500,000 \\
600,000\end{array}$ & $\begin{array}{l}412 \mathrm{Gel} \\
248 \mathrm{Gel}\end{array}$ \\
\hline
\end{tabular}




\section{RIO BLANCO MASSIVE HYDRAULIC FRACTURING EXPERIMENT}

CER Corporation

Las Vegas, Nevada

Interagency Agreement Date:

Anticipated Completion Date:

Project Cost (estimated):

Principal Investigator:

Technical Advisor for DOE:
Status: Awaiting Advisory

Committee Decision

December 31, 1978

DOE .

Industry $\ldots \ldots \ldots \ldots \ldots \ldots \ldots \ldots, 1,630,000$

Total . . . . . . . . . . \$3,605,000

G. R. Luetkehans

C. H. Atkinson

\section{OBJECTIVE}

This stimulation experiment is being conducted in low-permeability, massive gasbearing sandstone reservoirs in the Piceance Basin in western Colorado, to test advanced hydraulic fracturing technology where it has not been possible to obtain commercial production rates. This test is located about 1 mile from the 1973 Rio Blanco nuclear stimulation site to permit comparison of nuclear and hydraulic fracturing techniques in this area

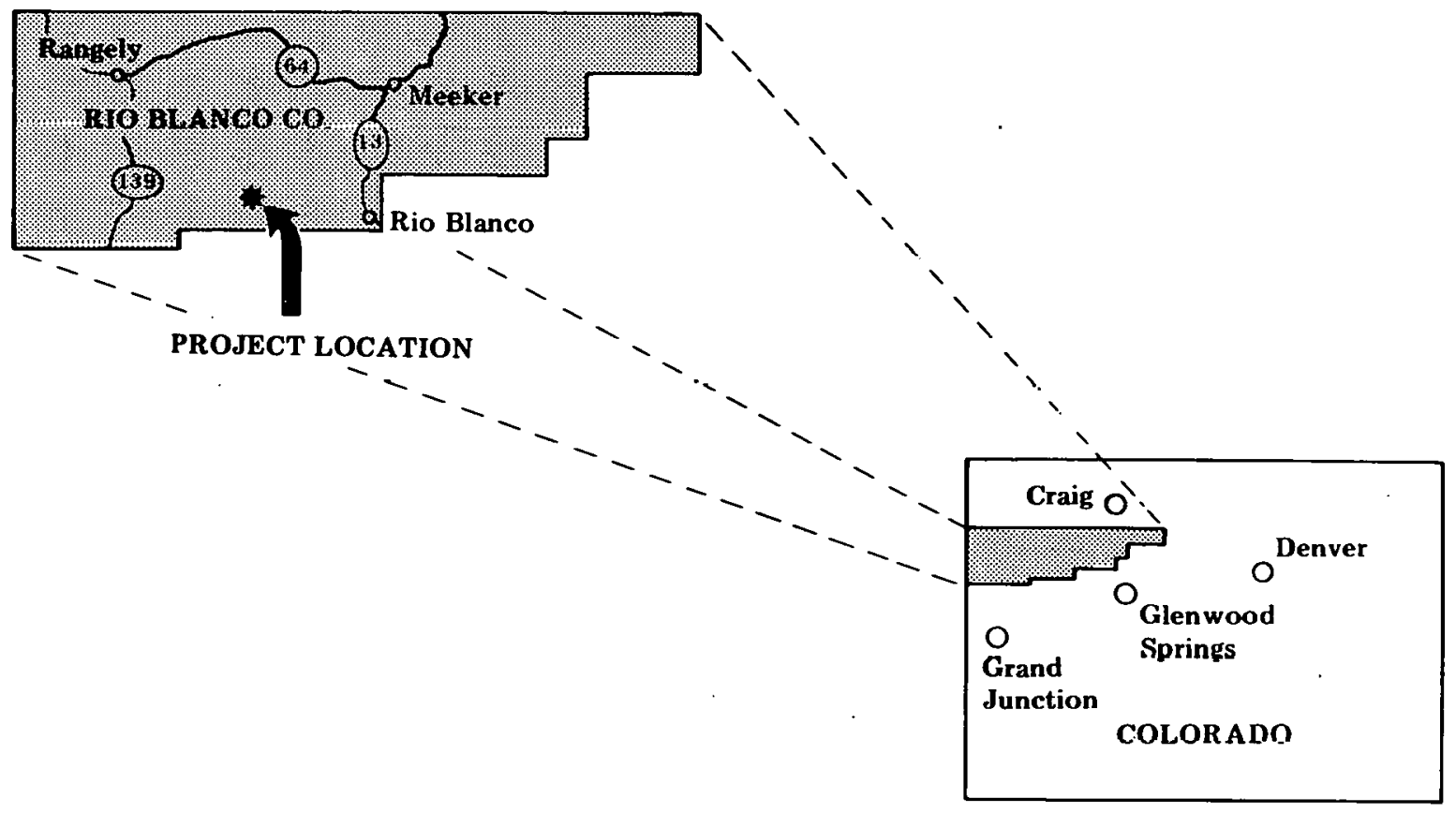




\subsection{CER CORPORATION}

\subsubsection{Summary of Past Activities}

DOE contract EY-76-C-08-0623 was awarded to CER Corporation in March 1974. The original contract provided for the drilling of a new well and two MHF treatments. Contract modifications added two additional MHF treatments and extended the term of the contract to an undisclosed date.

\subsubsection{Current Status}

Field activities on RB-MHF 3 well have been suspended. Negotiations have taken place with an outside party to complete the commingling of the fractured gas zones and to perform additional tests in return for the well and subsequent gas production. Legal documents are being prepared for distribution to the project participants for their concurrance. 
Contract Date:

Anticipated Completion Date:

Total Project Cost (estimated):

Principal Investigator:

Technical Project Officer for DOE:
September 1, 1977

March 1, 1981

$\operatorname{DOE} \ldots \ldots \ldots \ldots \ldots \ldots \ldots \ldots \ldots \ldots \ldots \ldots \ldots \ldots \ldots \ldots \ldots \ldots$
CIG $\ldots \ldots \ldots \ldots \ldots$

Total. $\$ 174,000$
Howard Fredrickson

C. H. Atkinson

\section{OBJECTIVE}

Cyclic injection of dry natural gas is the method to be used to increase production of tight gas sands.

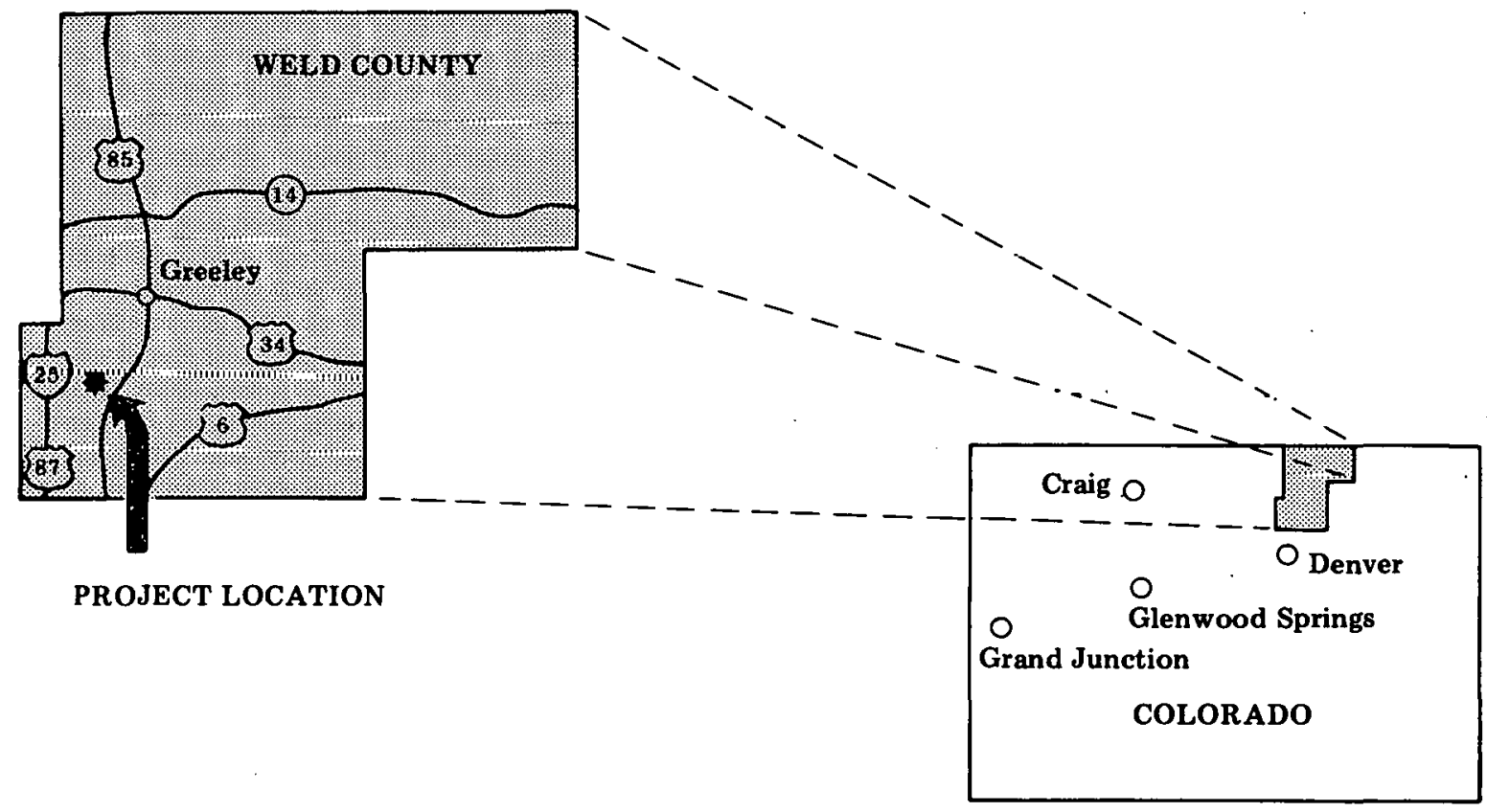




\subsection{COLORADO INTERSTATE GAS COMPANY}

\subsubsection{Scope of Work}

DOE and Colorado Interstate Gas Company (CIG) entered into Contract No. EY-77-C-081514 on September 1,1977 . The experiment will determine of productivity of wells completed in low-permeability natural gas reservoirs can be improved by reducing the interstitial water saturation by cyclic injection of dry natural gas. In addition, cyclic injection of dry natural gas may improve productivity by dehydrating matrix clays and by removal of formation damage adjacent to the surfaces of induced fractures.

\subsubsection{Current Status}

A special compressor has been ordered with delivery expected in December, 1978. The concrete pad for the compressor has been poured, and presently the pipeline is being laid between the wells. One additional month is required for completion of site preparation and BHP buildup, and the first cyclic injection-withdrawal is expected to begin around February 1, 1979. 


\section{NATURAL BUTTES UNIT, UINTAH COUNTY, UTAH MASSIVE HYDRAULIC FRACTURING DEMONSTRATION}

Gas Producing Enterprises, Inc.

Status: Active

Subsidiary of Coastal States Gas Co.

Houston, Texas

Contract Date:

Anticipated Completion:

July 1, 1976

September 30, 1979

Total Project Cost (estimated):

DOE . . . . . . . . . . . . . . \$2,827,000

Industry (prior costs) $\ldots \ldots \ldots \ldots \ldots \quad 1,881,000$

Industry (new costs) . . . . . . . . . 3,051,000

Total . . . . . . . . . . . \$ $\$ 7,759,000$

Principal Investigator:

Technical Project Officer for DOE:

W. E. Spencer

C. H. Atkinson

\section{OBJECTIVE}

To evaluate the effectiveness of massive hydraulic fracturing for stimulating natural gas production from thick, deep sandstone reservoirs having low-permeability.

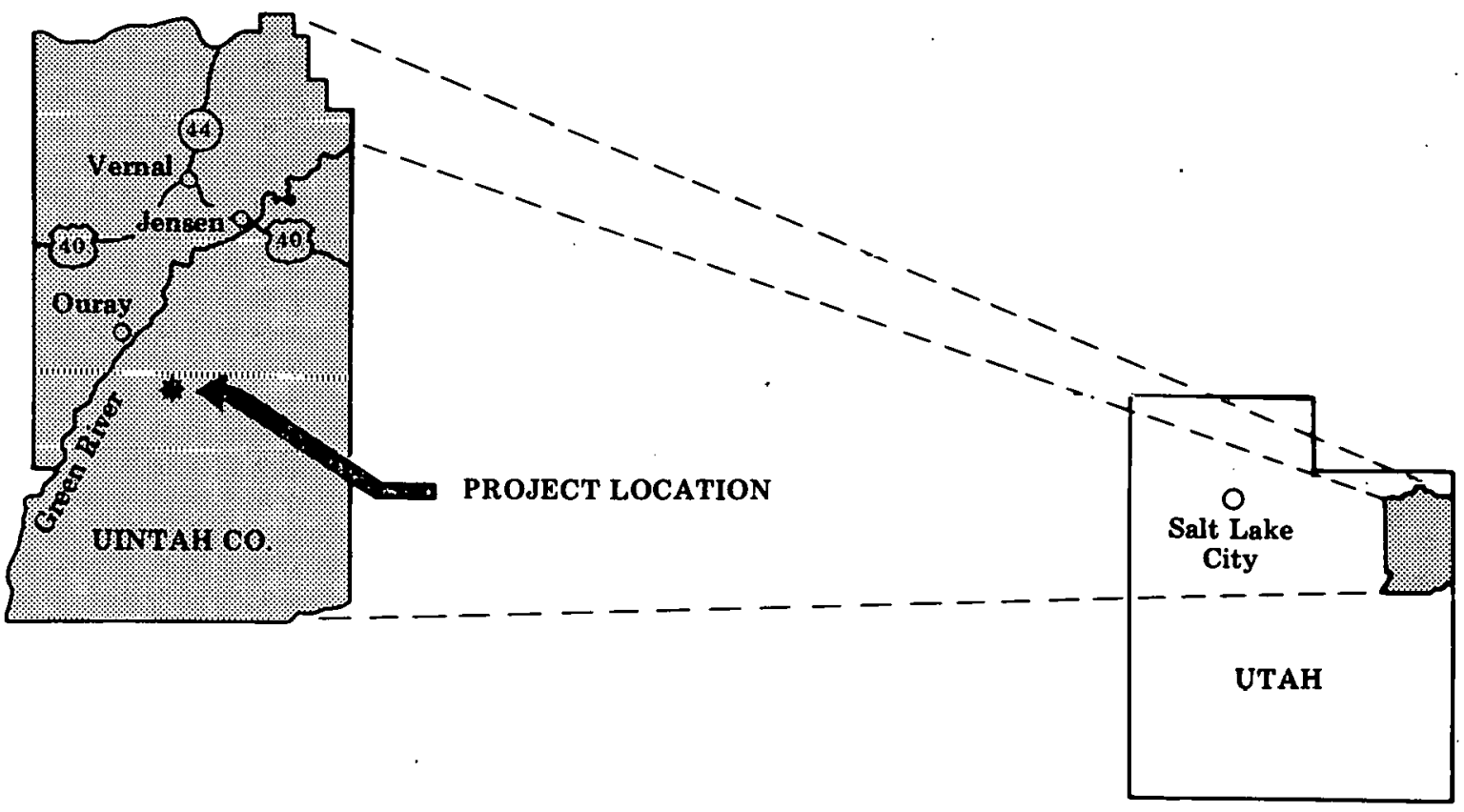




\subsection{GAS PRODUCING ENTERPRISES, INC.}

\subsubsection{Summary of Past Activities}

Gas Producing Enterprises was awarded DOE Contract EY-76-C-08-0681 in July, 1976. Originally, two old wells, Natural Buttes Unit Wells 14 and 18, and four new wells, 19, 20, 21 , and 22 were to receive MHF treatments. Three contract modifications have been entered into, adding one old well, Natural Buttes Unit No. 9, two new wells, 23 and CIGE 2-29-1021, and increasing the scope of work for Natural Buttes Unit Well No. 21.

\subsubsection{Current Status}

Natural Buttes Unit Wells No. 9, 14, 18, 19, 20 and 22 were flowing to sales during October. Production data for these wells appears in Figures 5-1 through 5-6.

Natural Buttes 21, perforated $(7,565-7,568 \mathrm{ft})$ on October 13, is being flow tested to the pit. The well made a small amount of water, and gas to small to measure after a breakdown with $1,000 \mathrm{gal}$ of acid.

Natural Buttes Unit No. 2 is presently shut in waiting on field proration, and Natural Buttes Unit 23, stimulated on October 4,1978 , is shut in waiting for pipeline connection permit from the Federal Energy Regulatory Commission.

Natural Buttes Unit 23 was stimulated with the following treatment:

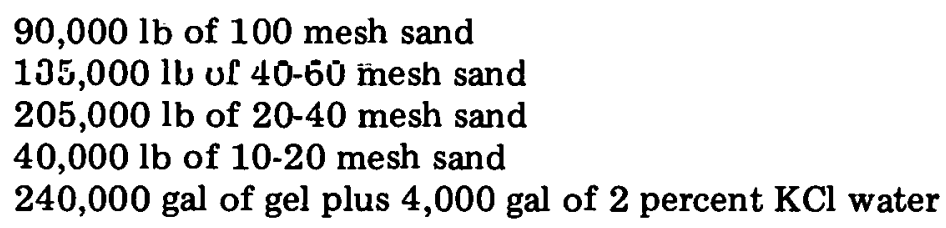

Future work includes continued analysis of the Natural Buttes Unit 21 core by Terra Tek, and continued production testing of open perfs at 7,563 - 7,570 ft. If the perforations continue to produce only water then a cast iron bridge plug will be set and movement up the hole to the next interval will commence. 


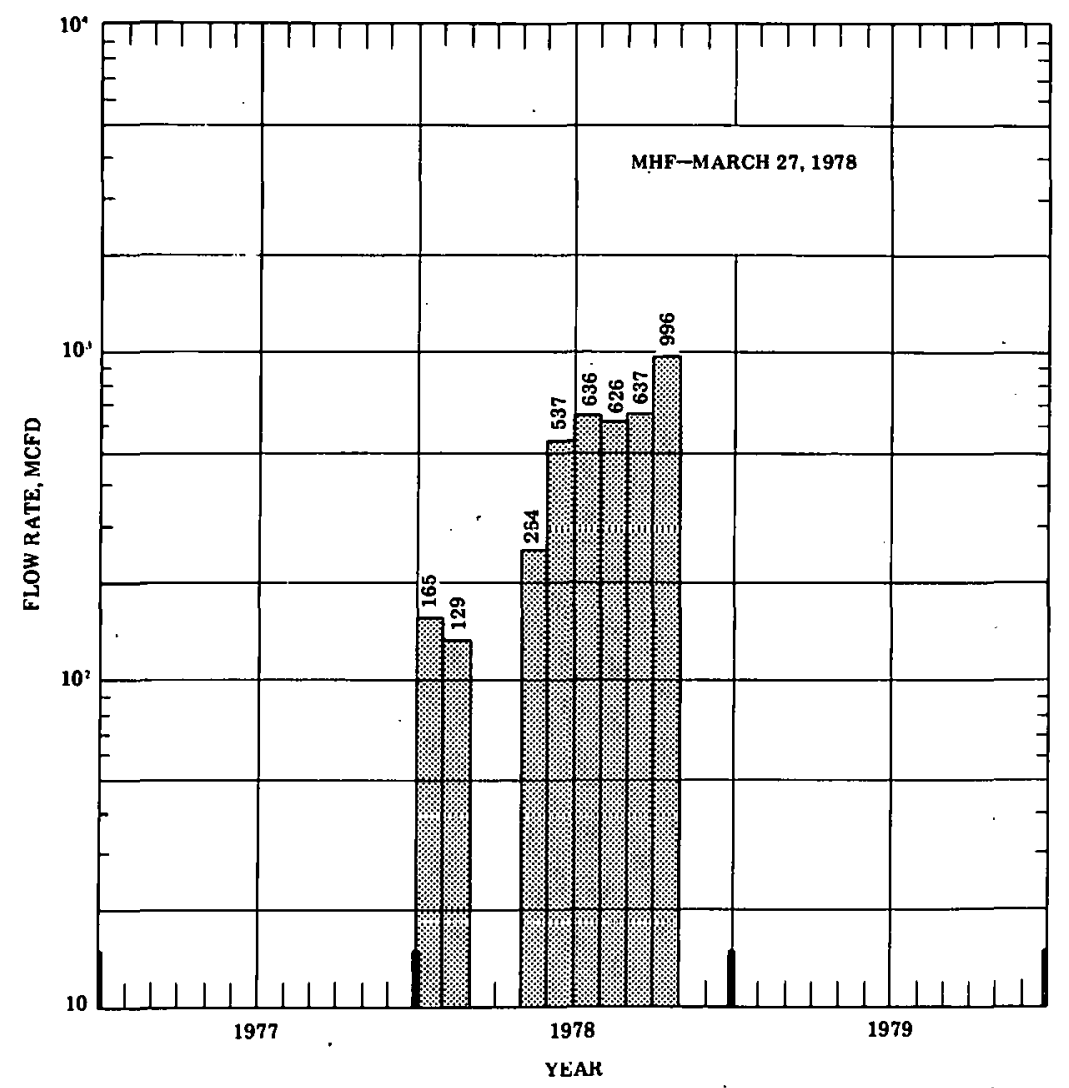

Figure 5-1

Flow Rate Performance of Natural Buttes No. 9 Well

Figure 5-2

Flow Rate Performance of Nalural Buttes No. 14 Well

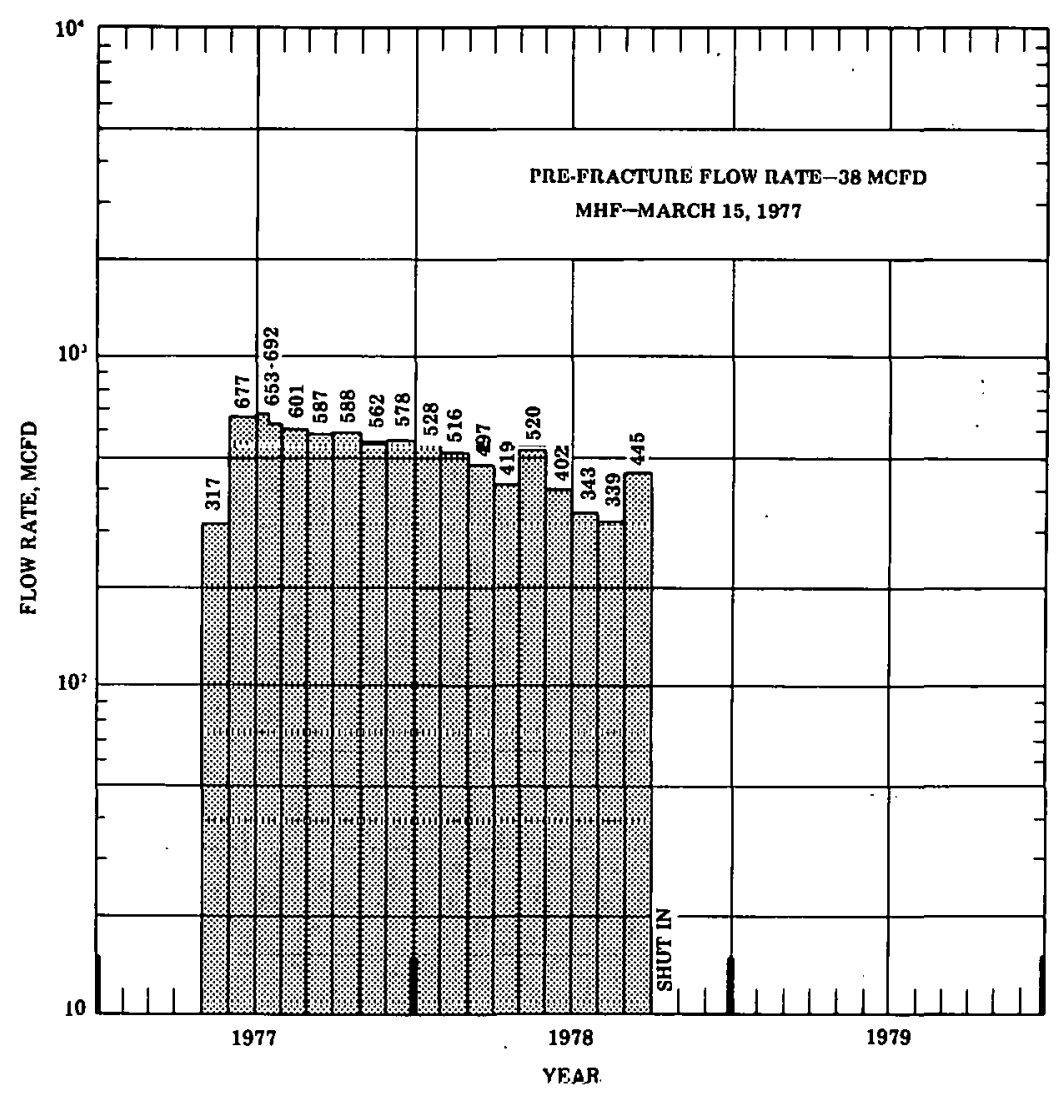


Figure 5-3

Flow Rate Performance of Natural Buttes No. 18

Well
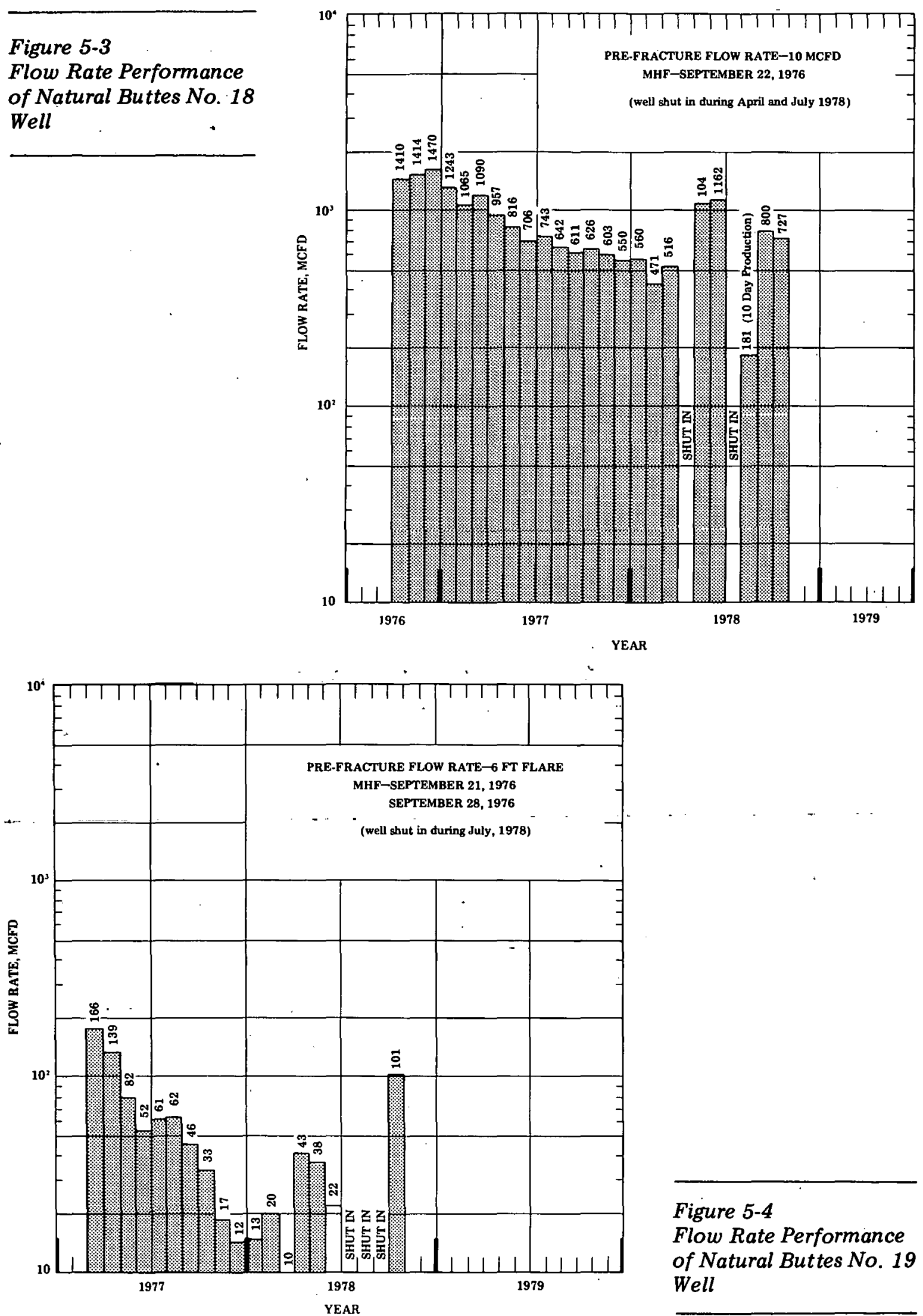

Figure 5-4

Flow Rate Performance of Natural Buttes No. 19 Well 


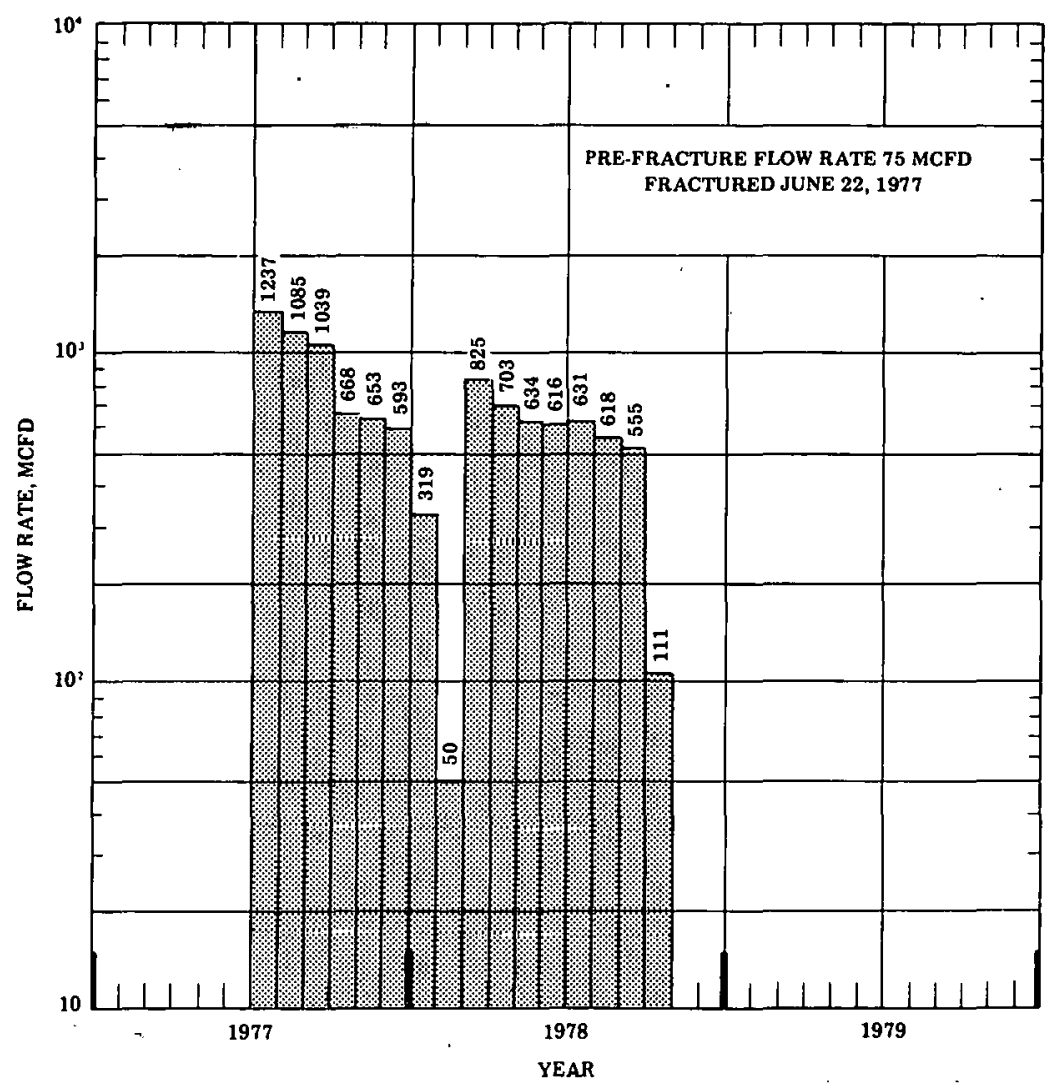

Figure 5-5

Flow Rate Performance of Natural Buttes No. 20 Well

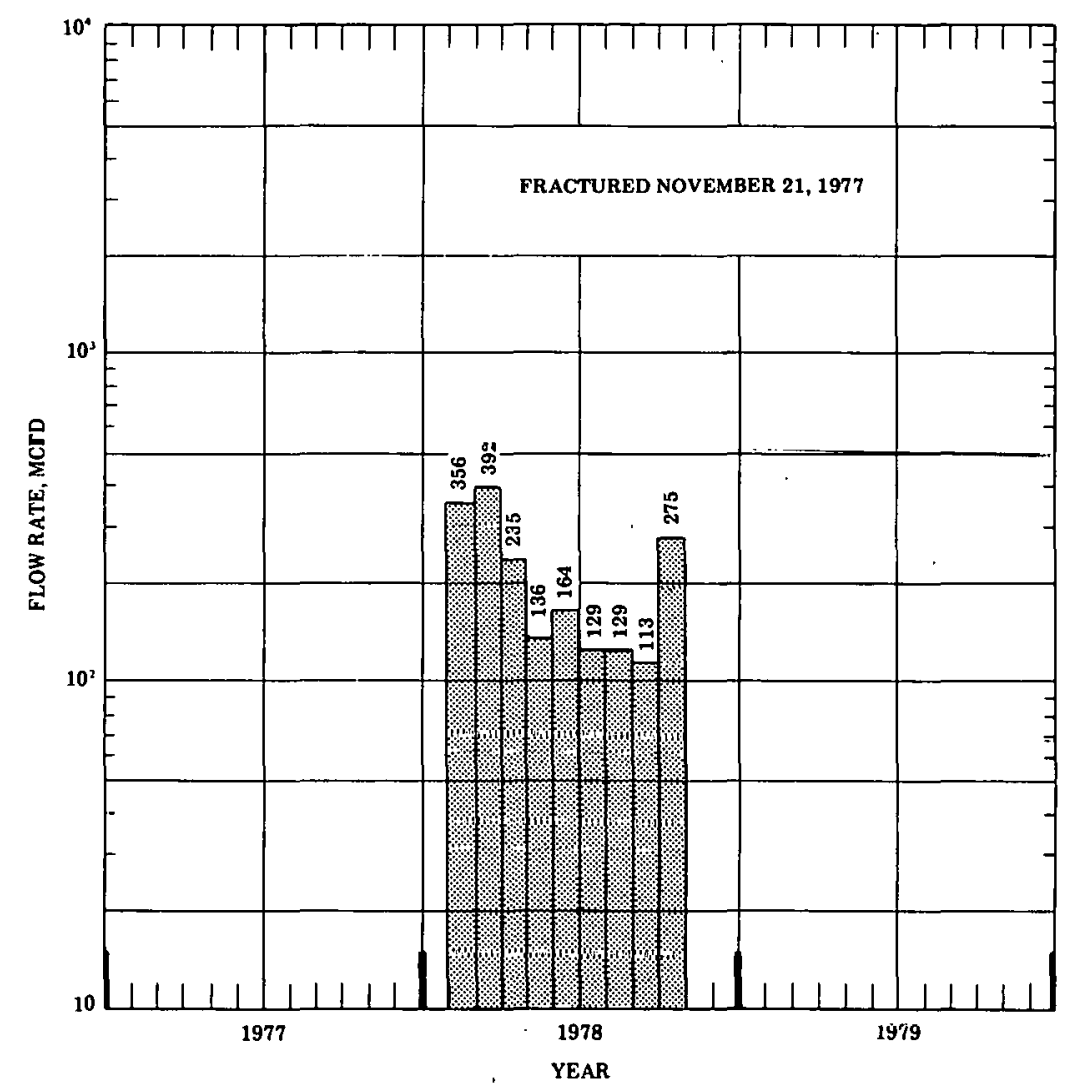

Figure 5-6

Flow Rate Performance of Natural Buttes No. 22 Well 
FALLON-NORTH PERSONVILLE FIELD,

Mitchell Energy Corporation

Status: Active

Houston, Texas

Contract Date:

Anticipated Completion:

Total Project Cost (estimated):

March 15, 1978

April 30, 1979

DOE ................ \$ 553,771

Industry $\ldots \ldots \ldots \ldots \ldots \ldots \ldots \ldots \quad 1,074,550$

Total .

$\$ 1,628,321$

Principal Investigator:

Technical Project Officer for DOE:

F. D. Covey

C. H. Atkinson

\section{OBJECTIVE}

To test massive hydraulic fracturing in the Cotton Valley Limestone Formation.

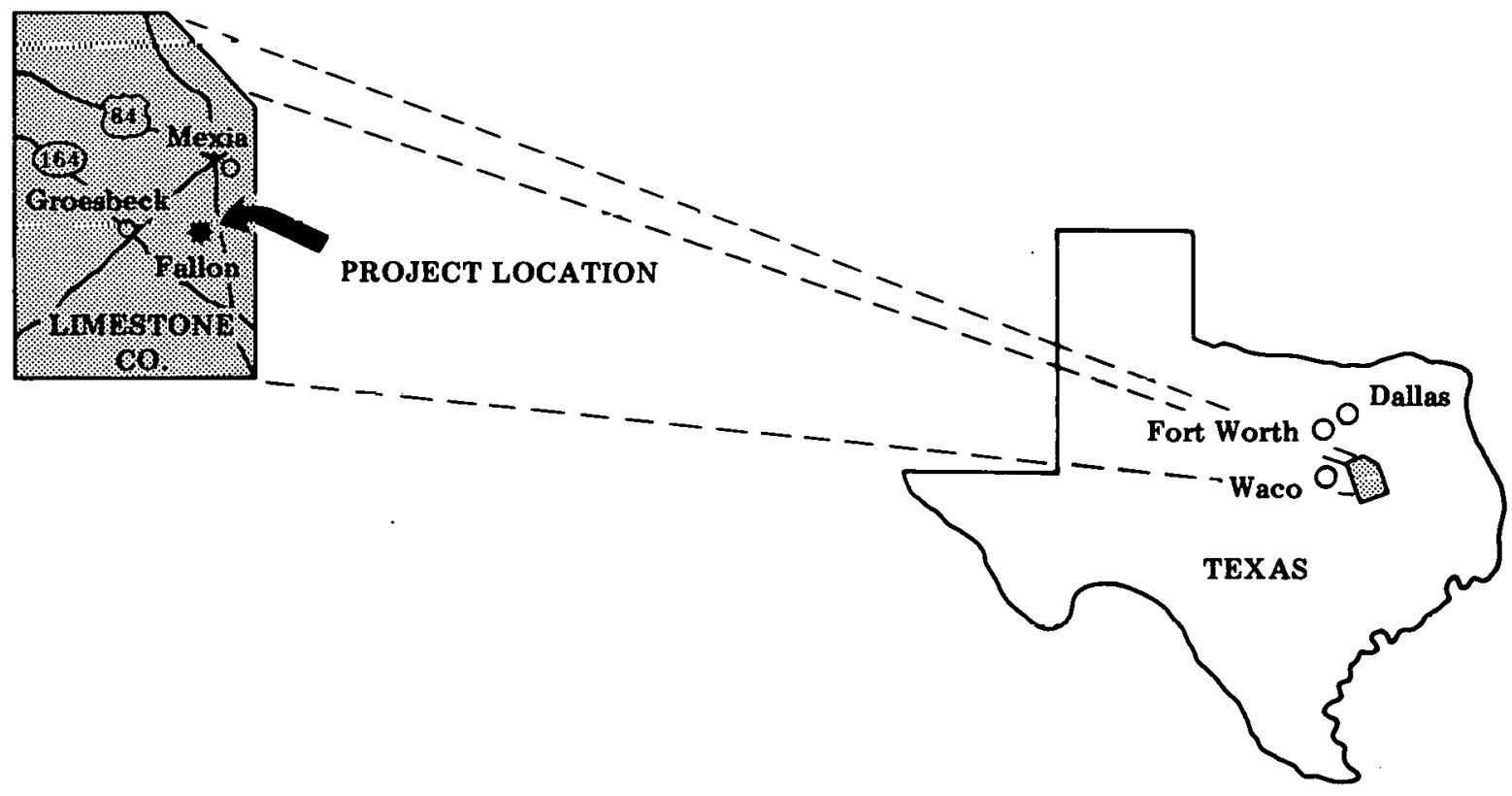




\subsection{MITCHELL ENERGY CORPORATION}

\subsubsection{Summary of Past Activities}

The Mitchell Energy Corporation Muse Duke No. 1 well flowed on a test at a rate of 2,034 MCFD through a $7 / 64$ in. choke at a flowing tubing pressure of 4,289 psi. On September 27 , the Cotton Valley Lime was perforated with 15 shots and each perforation was balled out. The formation was acidized with 15 percent $\mathrm{HCl}$ through the perforations. Bids for the massive fracture treatment were sent to several companies.

\subsubsection{Current Status}

The well is presently flowing on test at a rate of 2,100 MCF of gas with $3 \mathrm{BBL}$ of water per day through a $14 / 64$ in. choke with a flowing tubing pressure of 1,850 psi. Figure 5-7 shows the flowing tubing pressure and rates of the initial testing period. Preparations are being made to fracture the well on November 15, with approximately $1,000,000 \mathrm{gal}$ of fluid and $3,000,000 \mathrm{lb}$ of sand.

Since last reported, initial pressure transient tests have been conducted on the Cotton Valley Lime. The field recordings of the pressures and rates for the pressure transient tests were sent to CER Corporation and are available for inspection. Tandem Amerada pressure bombs were run for both the two-rate and buildup tests, conducted over a fiveday period. However, and as evidenced by the intermittently abrupt pressure changes at varying time frequencies, the bombs' gauges were sticking during both of the tests. Therefore, only the pressure inflections were utilized in the evaluations.

If at each change, the bombs read either the correct bottomhole pressure, or a constant proportion thereof, then a slope indicative of the formation's productive capacity should be obtained on the buildup plots. These pressure points as well as the other pertinent transient data were sent to CER Corporation for the buildup and two-rate tests, respectively.

The attached Figure 5-8 is the conventional "Horner" plot for the 16,350 lb gauge, while Figure 5-9 is for the 15,000 lb gauge. In addition, the bottomhole tubing pressure difference plot (Figure 5-10), and the "log-log" plot of pressure changes versus time after shut in (Figure 5-11) for the $15,000 \mathrm{lb}$ gauge were prepared for verification of the slopes, and for better delineations of the types of flows. Shown by these latter two figures, the start of the proper straight lines on the "Horner" plots is after a shut in time of approximately 40 hours. Thus, the pseudo-radial equations should be applicable subsequently to this time.

It should be noted on Figures 5-8 and 5-9, that an initial slope variance of only 5 psi-cycle was obtained. Thus, it was concluded that a plot of the above mentioned pressure reflections would yield reliable slopes. This is further substantiated by the fact that the quantitive evaluation did yield reservoir parameters that are very reasonable for the area. These parameters are tabulated on Table 5-2 for the 15,000 lb gauge. The corresponding values for the two-rate test are also shown on this in this table. 

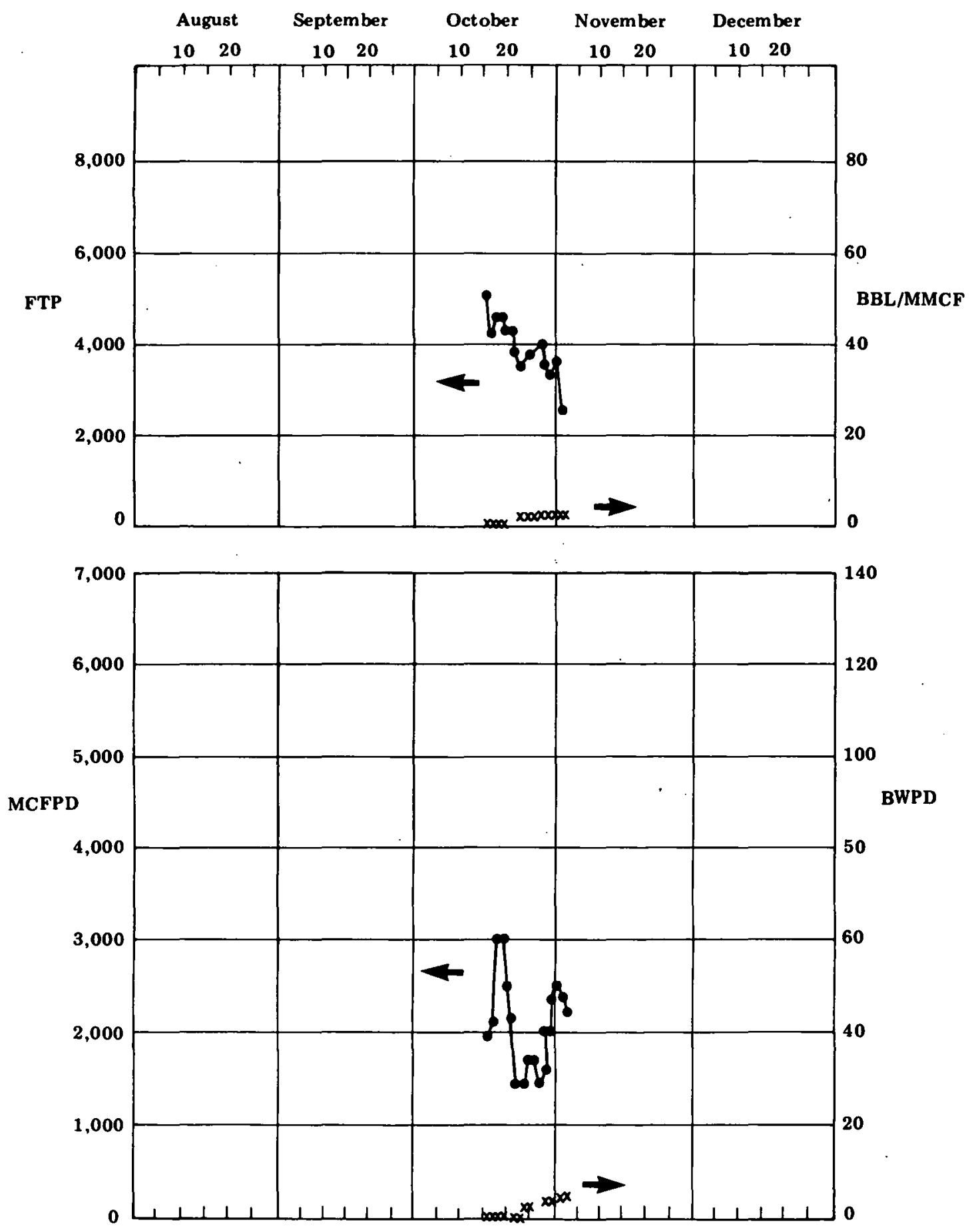

Figure 5-7 Flowing Tubing Pressure and Rates of Initial Testing Period 


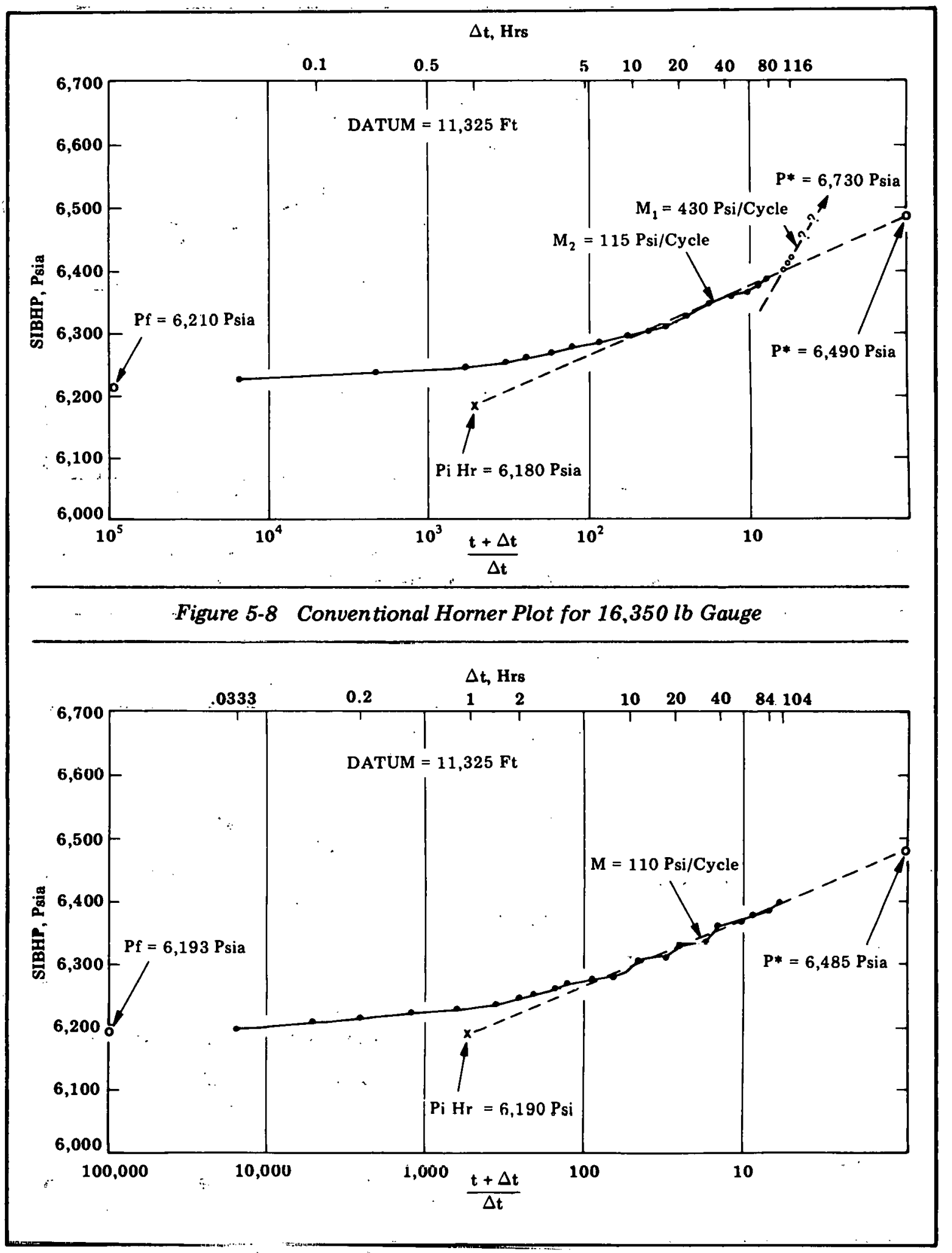

Figure 5-9 Conventional Horner Plot for 15,000 lb Gauge 


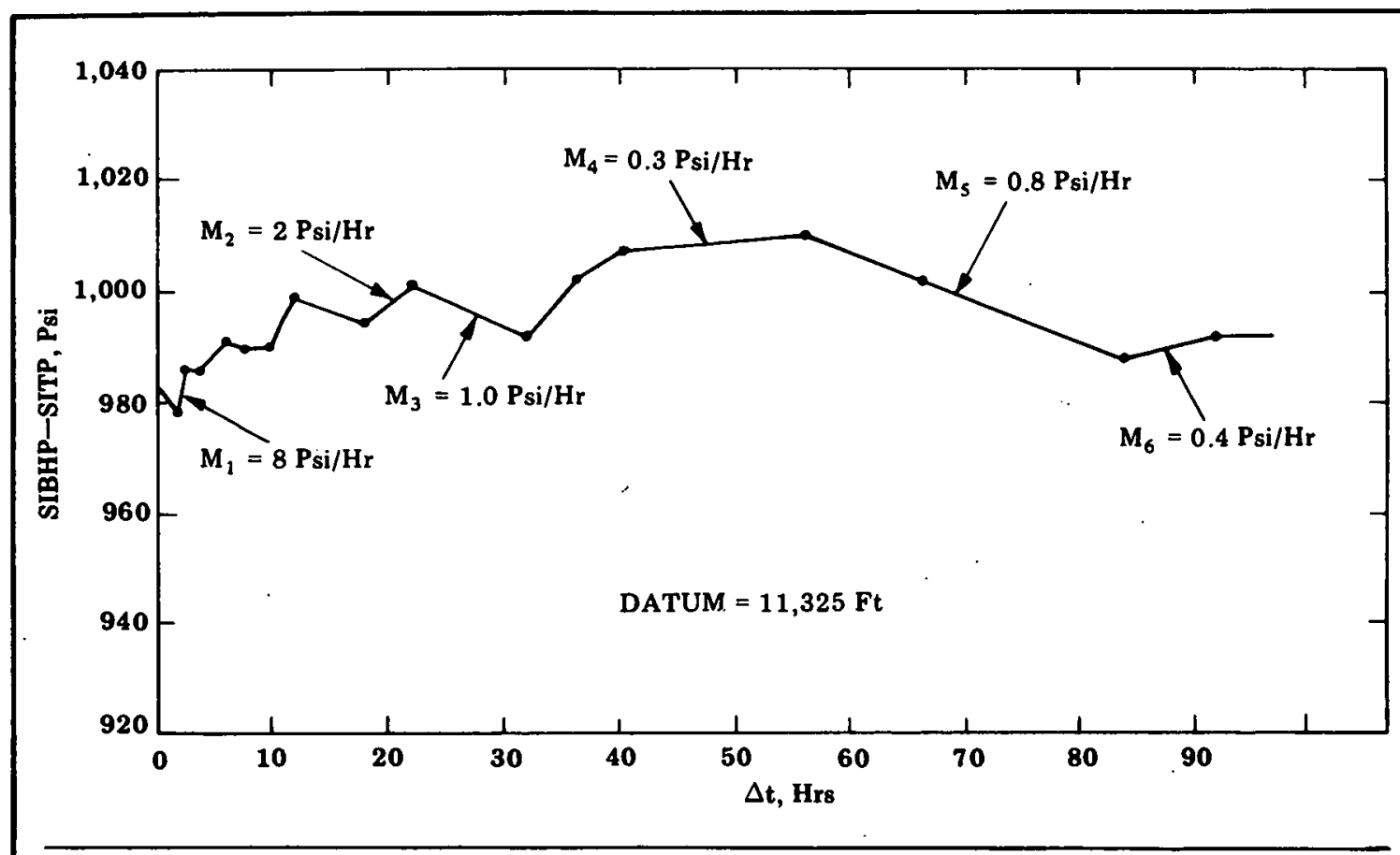

Figure 5-10 Bottomhole Tubing Pressure Difference Plot

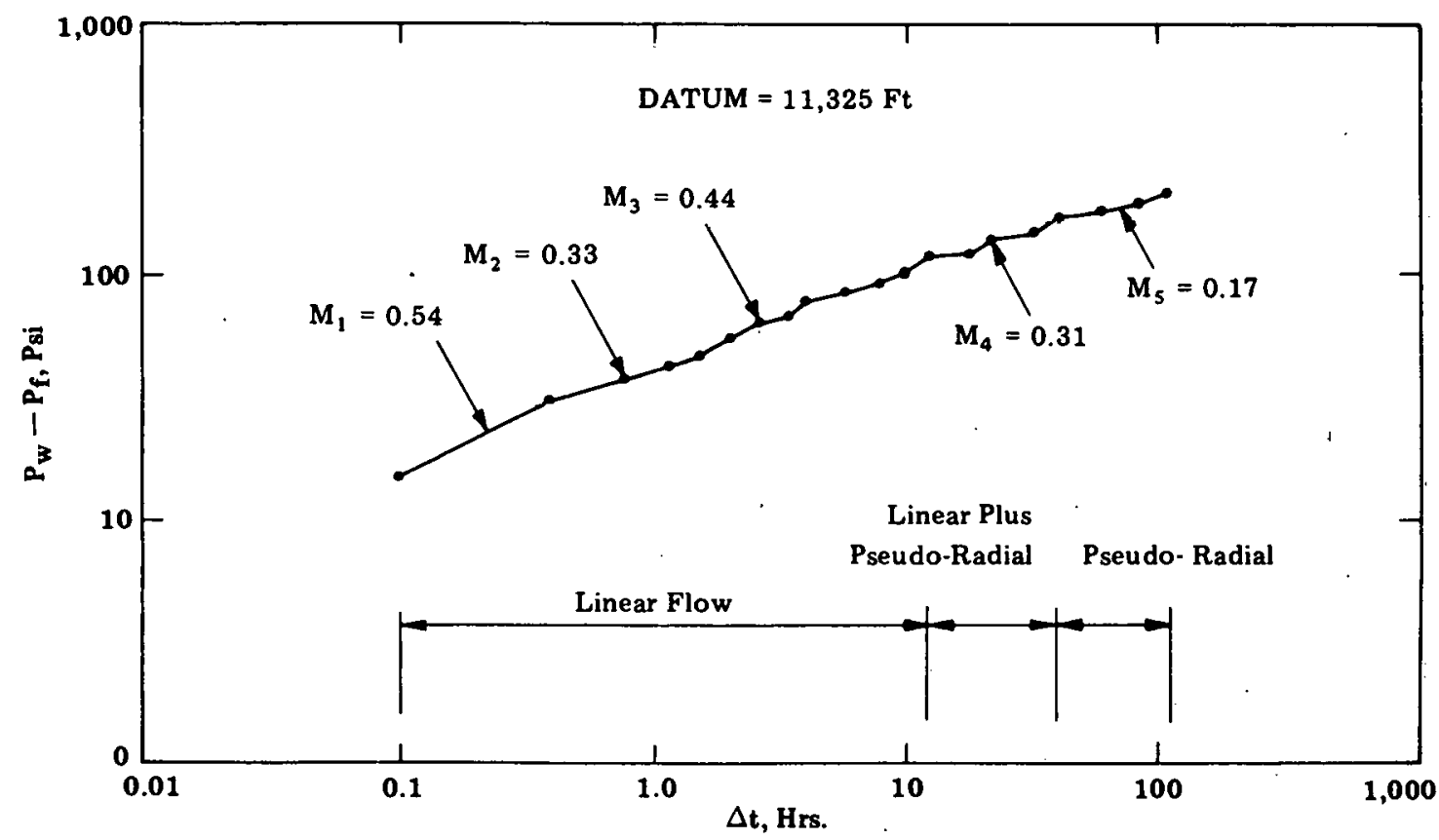

Figure 5-11 Log-Log Plot of Pressure Changes versus Time After Shut in for the 15,000 lb Gauge 


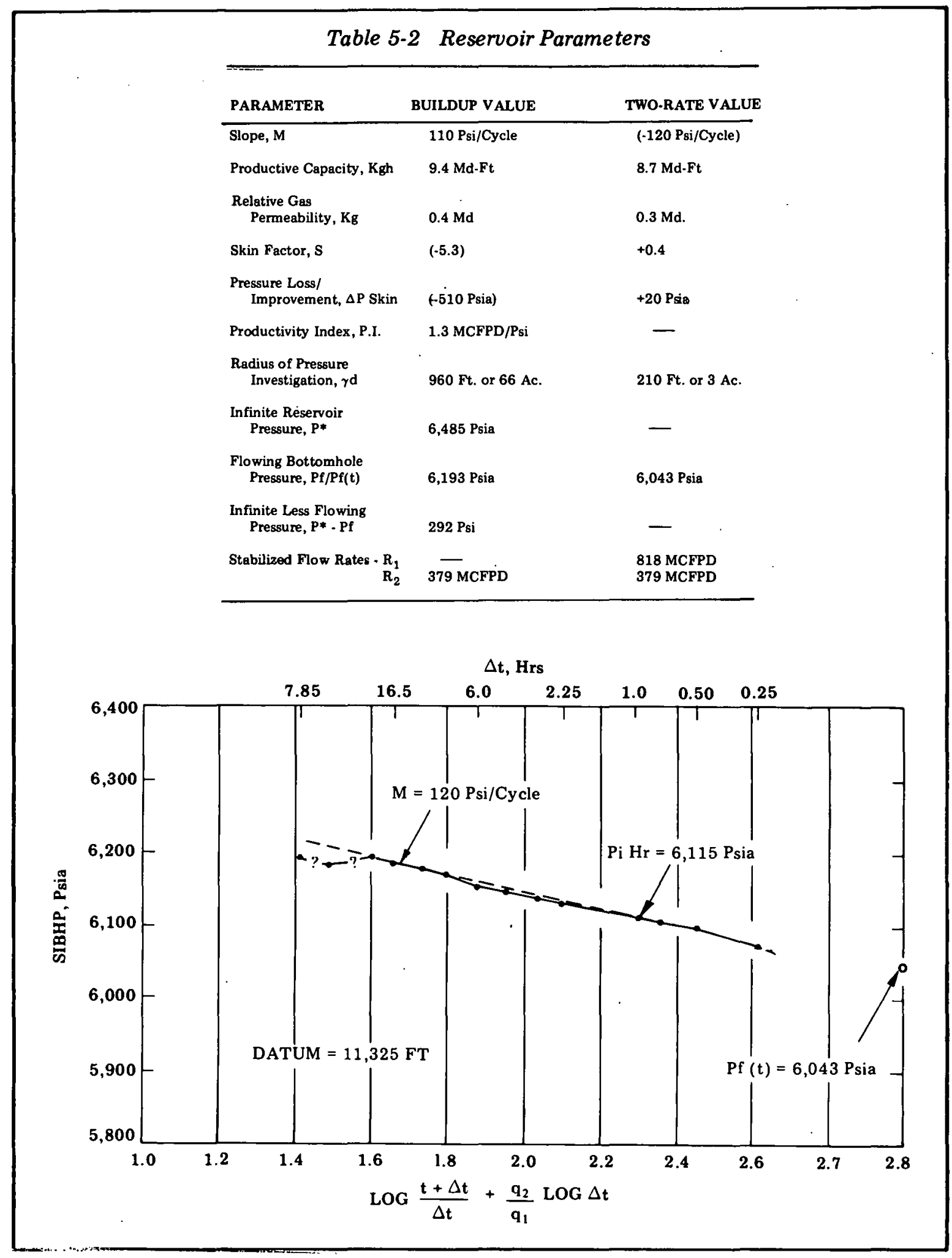

Figure 5-12 Conventional Plot for the Two-Rate Test 
The conventional plot, the flowing bottomhole tubing pressure difference plot, and the "log-log" plot of pressure changes for this test are shown as Figures 5-12 thru 5-14, respectively. The excellent agreement of the calculated productive capacities and resultant relative gas permeabilities should be noted (Table 5-2). This further validates the fact that the correct slopes were used.

It should also be noted that the last three pressure points on Figure $5-8(16,350 \mathrm{lb}$ gauge) yielded a slope of 430 psi-cycle, or an increase of 3.7 times the initial slope. However, as no slope changes were encountered on the "Horner" plot for the 15,000 lb gauge (Figure 5-9), nor on the two-rate test (Figure 5-12), and due to the abruptness of the pressure reflections, this increased slope is attributed to erroneous pressure recordings in lieu of a barrier, a lateral permeability variation, and/or cross flow.

In summary, the productive capacity is $9.4 \mathrm{md} \mathrm{ft}$; the relative gas permeability is $0.4 \mathrm{md}$, the skin factor is -5.3 ; and the productivity index is $1.3 \mathrm{MCFD} / \mathrm{psi}$.

Terra Tek's laboratory experiments with cores taken from the Mitchell Energy well were completed and the results summarized in the report, Fracturing Fluid Rock Interaction of Cotton Valley Lime Formation by U. Ahmed, L. Buchholdt and A. S. Abou-Sayed. The abstract of this report appears in Section 2.2.2, "Articles and Publications", of this report.

Terra Tek, to experimentally determine the effect of different fracturing fluids on the host rock, took core samples from Mitchell Energy Corporation Muse-Duke Well No. 1. All samples were one-inch diameter by one-inch long, with the axes normal to the core axis. First, permeability at atmospheric conditions for core at in situ saturation (40 percent) was determined. Upon subjecting the samples to in situ pressures $(8,800$ psia confining pressure, 6,400 psia pore pressure) and temperature $\left(285^{\circ} \mathrm{F}\right)$ permeability was again measured. While maintaining the confining pressure, pore pressure and temperature, fracturing fluid was flowed across one face of the sample for four hours at an injection pressure of 8,700 psia. These parameters simulated the field conditions. Twelve hours shut in time was allowed to assure that the fracture fluid was completely broken before backflow. On termination of shut in, permeability measurements were taken to determine the amount of damage.

Clean-up was simulated by introducing 6,400 psi nitrogen at the sample back face and reducing pressure at the fracture face. The following shows the schedule used.

\begin{tabular}{ccl}
$\begin{array}{c}\text { PRESSURE REDUCIION } \\
\text { AT FRACTURE FACE } \\
\text { psi }\end{array}$ & $\begin{array}{c}\text { DURATION OF } \\
\text { NITROGEN BACKFLOW } \\
\text { hrs }\end{array}$ & \multicolumn{1}{c}{ REMARKS } \\
\hline 500 & 3 & $\begin{array}{l}\text { Monitor permeability until } \\
100 \% \text { damage was recovered } \\
\text { or move on to the next step } \\
\text { if damage recovery stabilized }\end{array}$ \\
1,000 & 2 & $\begin{array}{l}\text { Same as above } \\
1,500\end{array}$ \\
2,000 & 2 & $\begin{array}{l}\text { Same as above } \\
\text { Monitor permeability until } \\
100 \% \text { damage was recovered } \\
\text { or stop test if damage re- } \\
\text { covery stabilizes. }\end{array}$ \\
\hline
\end{tabular}




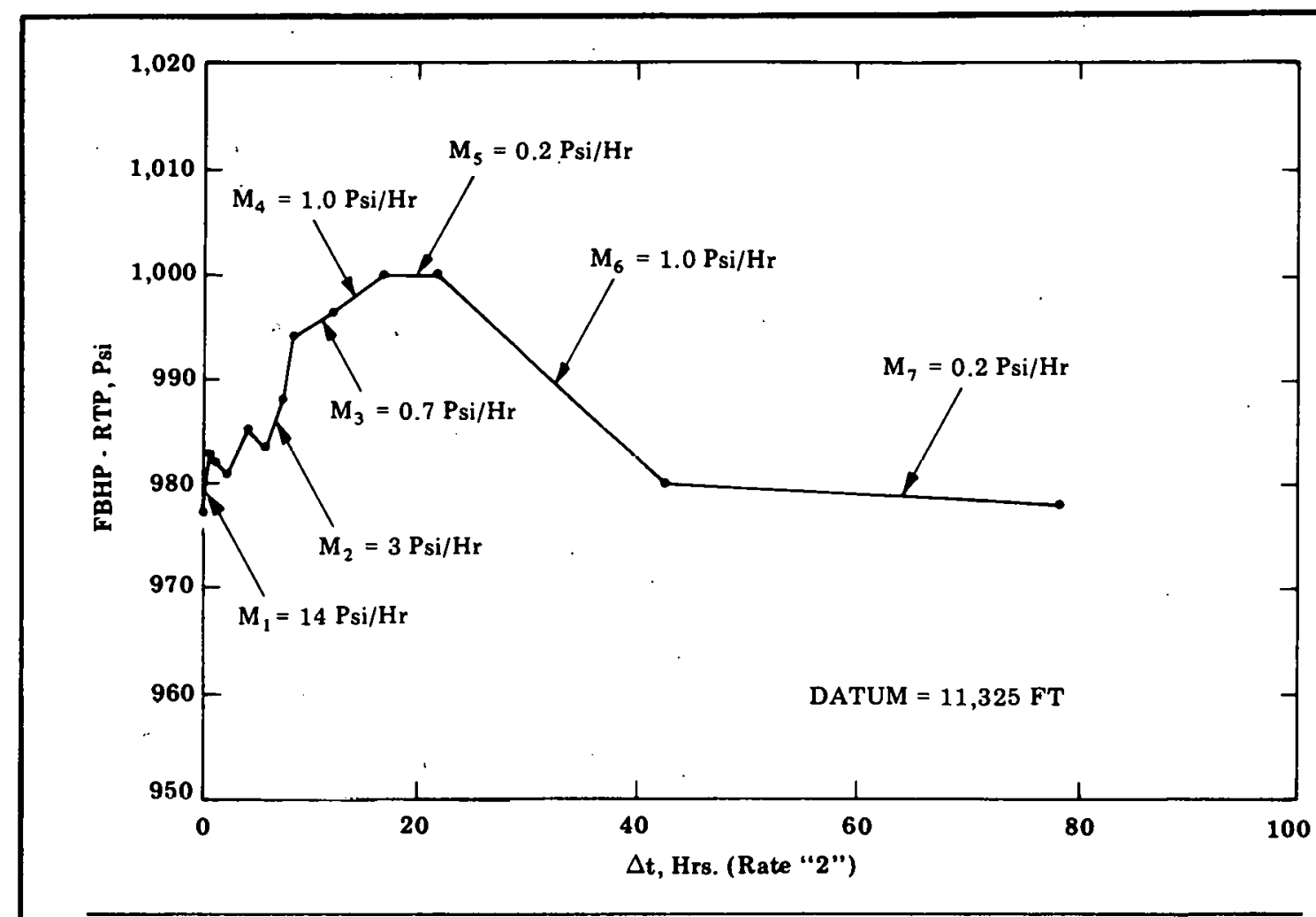

Figure 5-13 Flowing Bottomhole Tubing Pressure Difference Plot

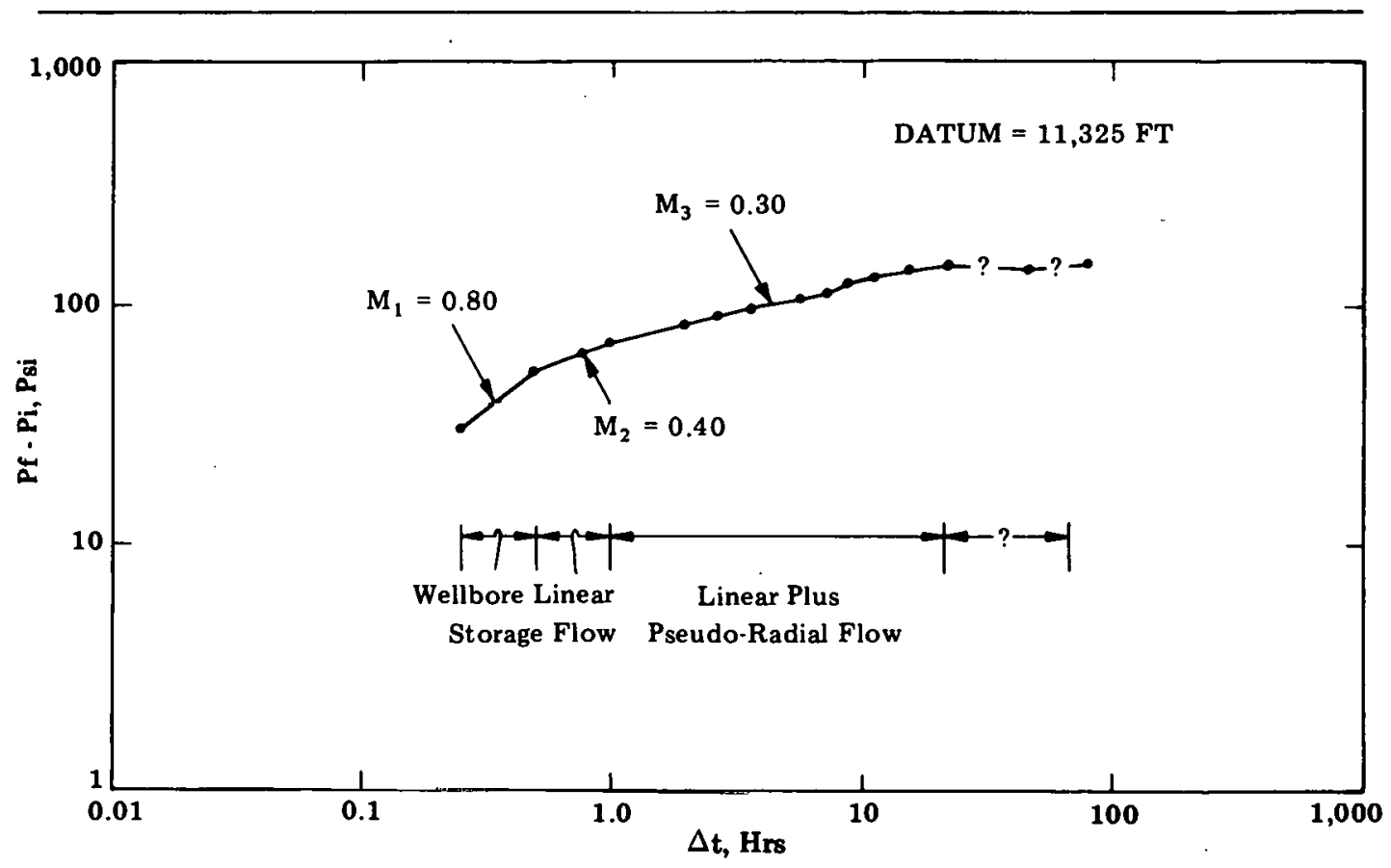

Figure 5.14 Log-Log Plot of Pressure Changes for the Tun-Rate Test 
The three different fracturing fluids evaluated were, Stratafrac 400, Versagel and Polaris 60. All the fluids were premixed by the individual companies.

The damage and clean up data on the crores are presented in Table 5-3 and Figure 5-15 and 5-16. The initial in situ permeabilities of the samples interacted by Stratafrac 400 and Versagel. were in the neighborhood of $25 \mu \mathrm{d}$, whereas the sample interacted by Polaris 60 was much higher $(83 \mu \mathrm{d})$. The damaged permeability of all the samples at initiation of clean up were in the tenths of micro-darcy range, irrespective of the initial permeability of the sample and fluid used. There was no evidence of the fracturing fluid flowing totally through the sample.

A differential pressure of 500 psi was adequate for the clean up of the samples damaged by Stratafrac 400 and Versagel. The sample damaged by Polaris 60 cleaned up about 50 percent on a 500 psi differential pressure. Permeability appeared to stabilize at this level even after 3 hours of backflow. After increasing the differential up to 2,000 psi, there was a 10 percent increase in damage recovery.

Figure 5-17 shows the sample assembly for the test set up. The sample is placed in a pressure vessel and the pore-pressure inlet and outlet are connected to external fittings through the base plug. With this geometry, the sample can be subjected to hydrostatic loading or triaxial compression prior to testing. Pore-pressure in the sample can be set at any value less than the confining pressure, and the desired backflow pressure can be applied. 
Table 5-3 Fracturing Fluid/Rock Interaction

\begin{tabular}{|c|c|c|c|c|c|c|c|c|c|c|c|c|}
\hline \multirow{2}{*}{$\begin{array}{l}\text { FRAC } \\
\text { FEUID }\end{array}$} & \multirow{2}{*}{$\begin{array}{c}\text { PERM AT } \\
\text { ATMOSPHERIC } \\
\text { CONDITION } \\
\mathrm{K}_{\mathrm{a}} \mu_{\mathrm{d}}\end{array}$} & \multirow{2}{*}{$\begin{array}{c}\text { PERM AT } \\
\text { IN SITU } \\
\text { CONDETIONS. } \\
\text { BEEOEE FRAC } \\
\text { FLUID FLOW, } \\
K_{\mathfrak{j}} \mu d\end{array}$} & \multirow{2}{*}{$\begin{array}{l}\text { FHRM AFTER } \\
\text { FRAC } \\
\text { FLUID FLOW, } \\
\text { K }_{s} \mu d\end{array}$} & \multicolumn{4}{|c|}{$\begin{array}{l}\text { TIME OF NITROGEN BACKFLOW } \\
\text { hrs }\end{array}$} & \multirow{2}{*}{$\begin{array}{l}\text { FINAL } \\
\text { DERM } \\
K_{f}, \mu_{d}\end{array}$} & \multicolumn{3}{|c|}{$\begin{array}{l}\text { RECOVERY FRACTION } \\
\mathbf{K} / \mathbf{K}_{\mathbf{i}}\end{array}$} & \multirow{2}{*}{$\begin{array}{c}\text { ESTMATED } \\
\text { 100\% } \\
\text { RECOVERY } \\
\text { TLME, hrs }\end{array}$} \\
\hline & & & & 800 & 1000 & 1500 & 2000 & & 500 & 10001500 & 2000 & \\
\hline $\begin{array}{l}\text { Strata- } \\
\text { frac } 400\end{array}$ & 159 & 23 & 0.2 & 2 & - & - & - & 22 & 0.96 & - & - & 2.2 \\
\hline Versageil & 991 & 31 & 0.3 & 1.5 & - & - & - & 25 & 0.81 & - & - & 1.7 \\
\hline Polaris 60 & 811 & 83 & 0.1 & 3 & 0.5 & - & 0.5 & 48 & 0.49 & $0.54-$ & 0.58 & Inconclusive \\
\hline
\end{tabular}

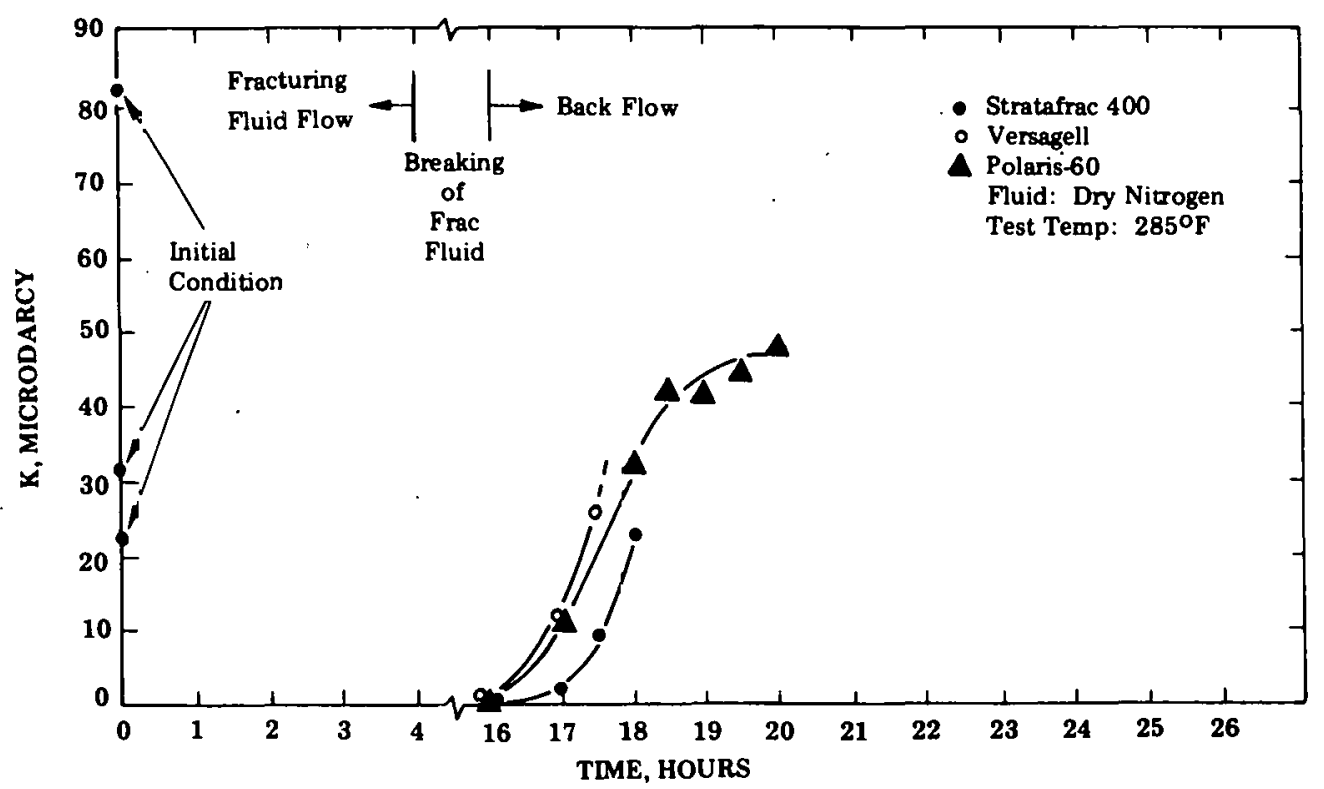

Figure 5-15 Change in Permeability During Damage and Clean Up 

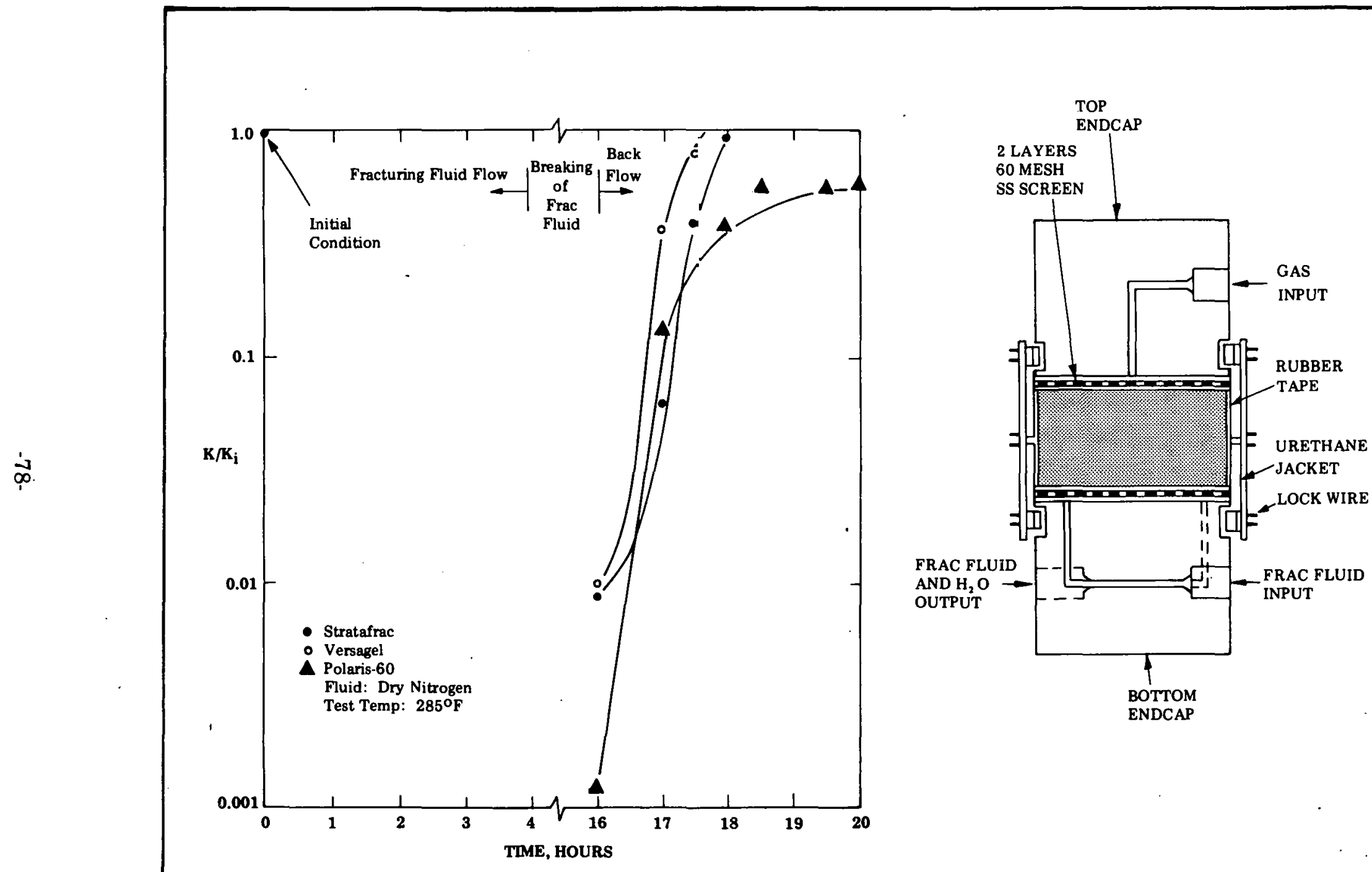

Figure 5-16 Trend of Permeability Fraction During Damage and Clean Up 
PICEANCE CREEK FIELD, COLORADO,

EY-76-C-08-0678

MASSIVE HYDRAULIC FRACTURING

DEMONSTRATION

Mobil Research and Development Corporation

Status: Active

Dallas, Texas

Contract Date:

July 1,1976

Anticipated Completion:

December 31, 1978

Total Project Cost (estimated):

DOE . . . . . . . . . . . . . \$2,510,000

Contractor (prior costs) . . . . . . 2,376,485

Contractor (new costs) . . . . . . . 1,590,515

Total

$\$ 6,477,000$

Principal Investigator:

John I.. Fitch

Technical Project Officer for DOE:

C. H. Atkinson

\section{OBJECTIVE}

To evaluate the effectiveness of massive hydraulic fracturing for stimulating natural gas production from thick, deep sandstone reservoirs having extremely low-permeability.

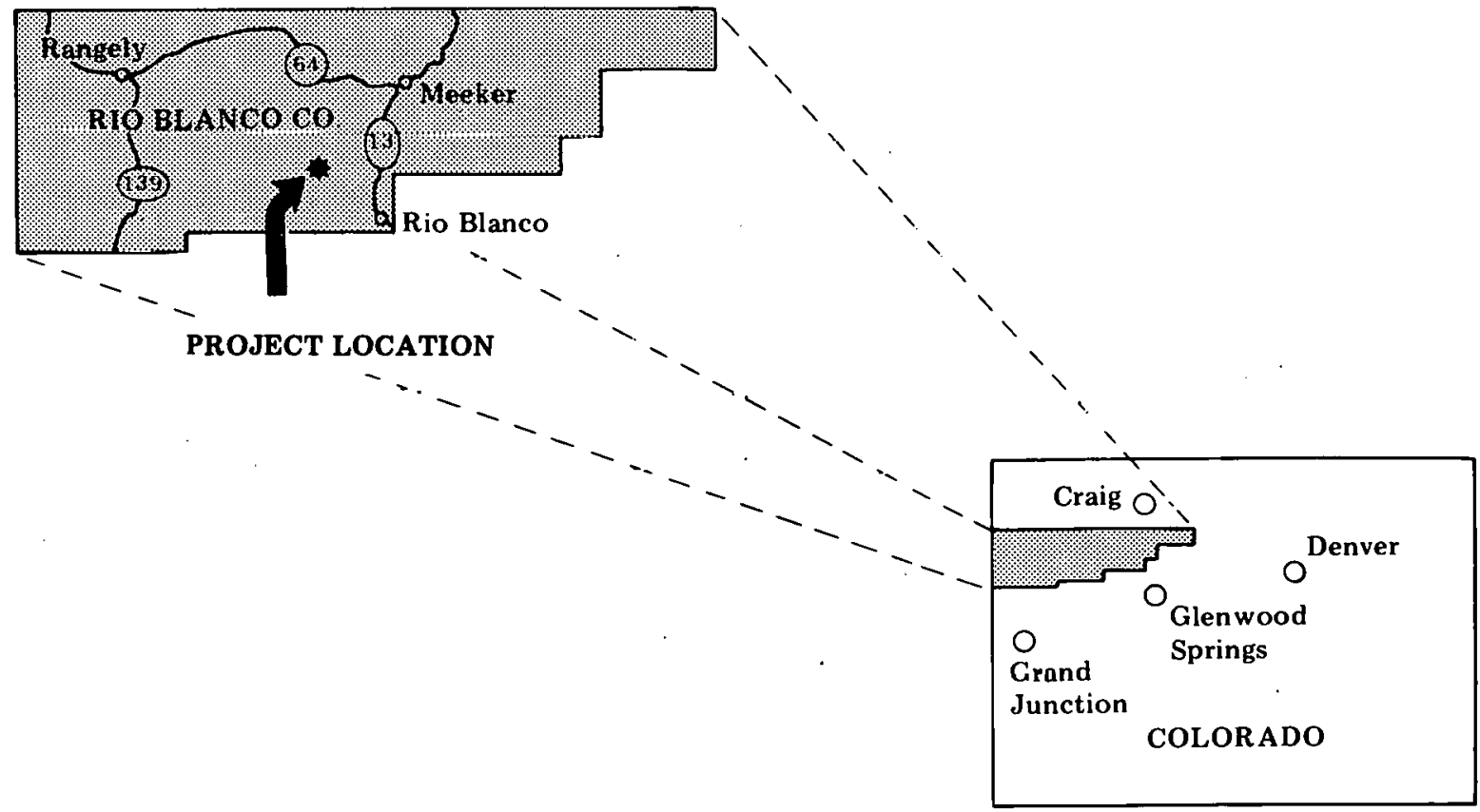




\subsection{MOBIL RESEARCH AND DEVELOPMENT}

\subsubsection{Summary of Past Activities}

Zone 8 was fractured on September 7,1978 . The most severe treating pressure to date was encountered while pumping the treatment. Initial ISIP was $800 \mathrm{psi}$, after pumping $3,000 \mathrm{gal}$ of pad. Initial (static) treating pressure measured on the tubing, while pumping the gel was $900 \mathrm{psi}$. Pressure increased rapidly to about 3,400 psi when sand-out occurred after pumping $218,000 \mathrm{lb}$ of $20-40$ mesh sand in $120,000 \mathrm{gal}$ of gel at $15 \mathrm{bpm}$. Table 5-4 is a summary of the Mobil well completion information and Figure 5-18 illustrates the treated zones 6, 7 and 8.

\subsubsection{Description of Technical Progress}

Most of October was spent in completing preparations for perforating and testing Zone 9. Following remedial cementing on Zone 9, the upper perfs failed to hold pressure. These perfs were successfully squeezed on October 10 . The cement retainer was drilled on October 12 and a bond $\log$ run. Poor bonding was observed between Zone 9 and the bottom set of perfs at 7,510 $\mathrm{ft}$. Bond was improved by the squeeze. After drilling out cement, attempts were started to move the bridge plug to above the lower cementing perfs. After several days of effort, the plug was jarred loose on October 25. While coming out of the hole with the plug, pressure built up below it and blew the plug and retrieving tools out of the hole. No one was hurt and the well was quickly brought under control. Only modest physical damage was incurred. A drillable plug was set below the zone on October 30.

The zone was perforated between $7,324=7,470 \mathrm{ft}$ with 77 shots (one sinot per two feet) on October 31 through November 1. After perforating, the well flowed at 650 psi wellhead pressure through a 3/4 in. choke. Figure 5-18 shows the intervals treated and Table 5-4 is a summary of completion information.

\subsubsection{Future Plans}

Zone 9 will be broken down with 2 percent $\mathrm{KCl}$ water and ball sealers, flowed for three days and shut-in for pressure buildup. If suitable for MHF, the zone will be fractured with $700,000 \mathrm{lbs}$ of $20-40$ mesh sand carried by $365,000 \mathrm{gal}$ of gel at $60 \mathrm{bpm}$.

Note: After breakdown on November 1-2, the well flowed 2 MMCF gas plus 70 BBL water/day declining to $1 \mathrm{MMCF} /$ day gas plus $500 \mathrm{BBL}$ water/day in three days. The frac is scheduled for November 15 . 

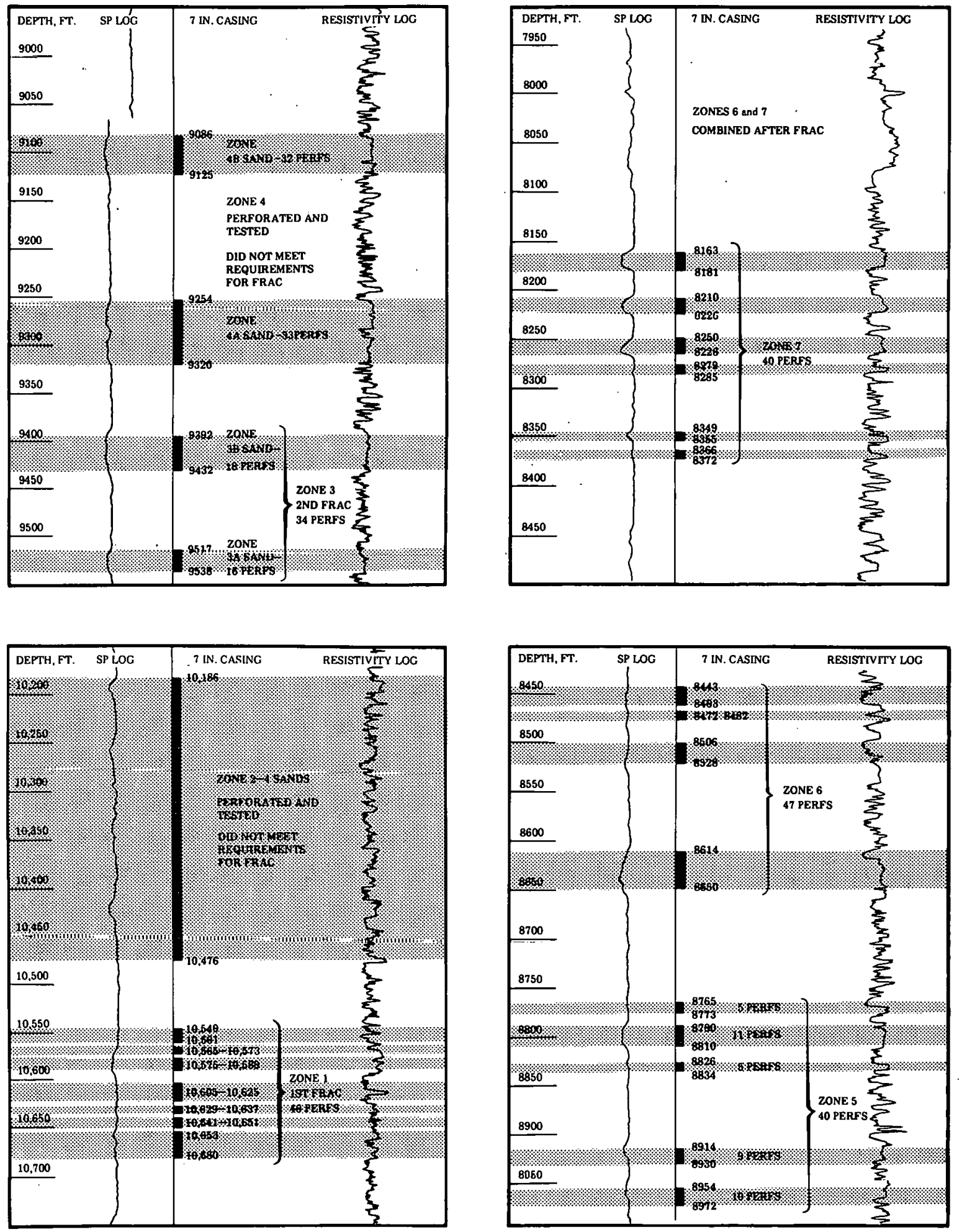

Figure 5-18 Mobil F31-13G Well Showing Sands Fractured 


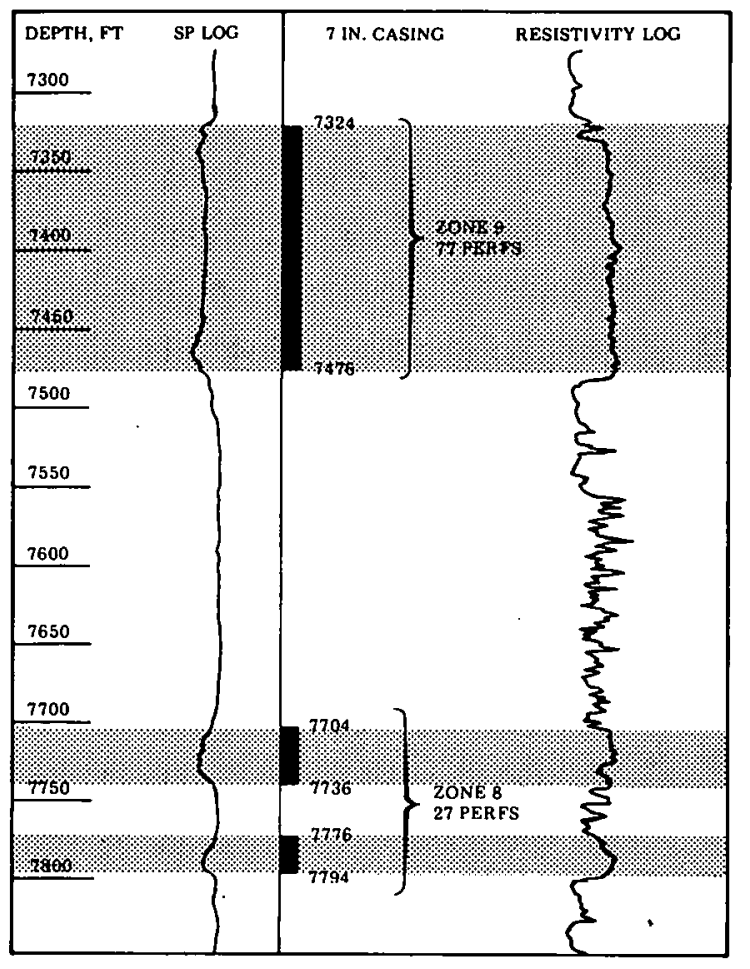

Figure 5-18 Continued

\section{Table 5-4 PCU No. 31-13G Completion} Information

\begin{tabular}{|c|c|c|c|c|c|c|c|c|c|c|}
\hline \multirow[b]{2}{*}{ Zone } & \multirow[b]{2}{*}{ No. } & \multirow[b]{2}{*}{$\begin{array}{l}\text { Perfs Interval } \\
\end{array}$} & \multirow[b]{2}{*}{$\begin{array}{c}\text { PBTD, } \\
\mathrm{ft} .\end{array}$} & \multirow[b]{2}{*}{ Tubing } & \multirow[b]{2}{*}{ Packer } & \multirow[b]{2}{*}{$\begin{array}{c}\text { Gas } \\
\text { Gravity }\end{array}$} & \multirow[b]{2}{*}{ Temp. } & \multirow[b]{2}{*}{ Porosity } & \multicolumn{2}{|c|}{ Pressure Transient Tests } \\
\hline & & & & & & & & & $\begin{array}{c}\text { Before } \\
\text { Frac }\end{array}$ & $\begin{array}{c}\text { After } \\
\text { Frac }\end{array}$ \\
\hline 1 & 46 & $10.549 \cdot 10,680$ & 10,730 & $2 \cdot 3 i 6 @ 10,450$ & None & N.A. & 236 & \multirow{8}{*}{ 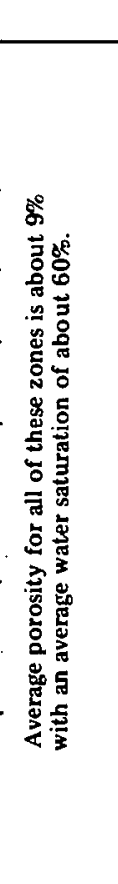 } & PRII & PBU \\
\hline 2 & $\begin{array}{r}10 \\
2 \\
4 \\
10 \\
3 \\
\end{array}$ & $\begin{array}{l}10,186 \cdot 10,196 \\
10,202 \cdot 10,204 \\
10,255 \cdot 10,261 \\
10,415 \cdot 10,427 \\
10,472 \cdot 10,476\end{array}$ & 10,530 & ….... & $\cdots$ & N.A. & 230 & & None & $\begin{array}{l}\text { Not } \\
\text { Fractured }\end{array}$ \\
\hline 3 & $\begin{array}{l}18 \\
16 \\
\end{array}$ & $\begin{array}{l}9,392-9,432 \\
9,517 \cdot 9,538 .\end{array}$ & 9,600 & $2-7 / 8 @ 9,120$ & 9,120 & 0.678 & 215 & & PBU & PBU \\
\hline $4 \mathrm{~A}$ & 33 & $9,254 \cdot 9,320$ & 9,370 & $2-3 / 8 @ 9,150$ & None & N.A. & 212 & & PBU & $\begin{array}{l}\text { Not } \\
\text { Fractured } \\
\end{array}$ \\
\hline $4 B$ & 32 & $9,086-9,124$ & 9,210 & $2 \cdot 3 / 8 @ 8,980$ & None & N.A. & 209 & & PBU & $\begin{array}{l}\text { Not } \\
\text { Fractured }\end{array}$ \\
\hline 5 & $\begin{array}{r}5 \\
11 \\
5 \\
9 \\
10\end{array}$ & $\begin{array}{l}8,765 \cdot 8,773 \\
8,790 \cdot 8,810 \\
8,826 \cdot 8,834 \\
8,914 \cdot 8,930 \\
8,954-8,972\end{array}$ & 9,040 & $2-3 / 8 @ 8,625$ & None & 0.669 & 205 & & PBU & PDD \\
\hline 6 & $\begin{array}{r}10 \\
6 \\
12 \\
19 \\
\end{array}$ & $\begin{array}{l}8,443-8,463 \\
8,472-8,482 \\
8,506-8,528 \\
8,614-8,650\end{array}$ & 8,725 & $2-3 / 8 @ 8,300$ & None & $\begin{array}{l}\text { Zones } 6 \\
\text { and } 7 \\
\text { combined }\end{array}$ & 199 & & PBU & $\begin{array}{l}\text { Pressure } \\
\text { drawdown } \\
\text { (PDD) test } \\
\text { was run }\end{array}$ \\
\hline 7 & $\begin{array}{r}10 \\
9 \\
9 \\
4 \\
4 \\
4 \\
\end{array}$ & $\begin{array}{l}8,163 \cdot 8,181 \\
8,210 \cdot 8,226 \\
8,250-8,266 \\
8,279-8,285 \\
8,349-8,355 \\
8,366-8,372 \\
\end{array}$ & 8,425 & $2 \cdot 3 / 8 @ 8,050$ & None & $\begin{array}{l}\text { after frac } \\
0.668\end{array}$ & 194 & & PBU & $\begin{array}{l}\text { Zones } 6 \\
\text { and } 7 \\
\text { combined } \\
\text { after frac }\end{array}$ \\
\hline 8 & $\begin{array}{l}27 \\
27\end{array}$ & $\begin{array}{l}7,704-7,736 \\
7,776-7,794\end{array}$ & 7,812 & 2-3/8,@7,675 & 7,675 & N.A. & 191 & & PBU & \\
\hline
\end{tabular}

* From temperature logs run over various intervals at different times, the geothermal temperature gradient through the Mesaverde averaged about $1.75^{\circ} \mathrm{F} / 100 \mathrm{ft}$.

Note: Casing is 7 in., $26 \mathrm{lb}$ set at $10,800 \mathrm{ft}$. 
Rio Blanco Natural Gas Company Denver, Colorado

Contract Date:

Anticipated Completion:

Total Project Cost (estimated):

Principal Investigator:

Technical Project Officer for DOE:

\section{August 1, 1976}

December 15, 1978

DOE .................\$ 410,000

Contractor. . . . . .

Total............ $\$ 1,003,000$

Robert E. Chancellor

C. H. Atkinson

\section{OBJECTIVE}

To evaluate the effectiveness of massive hydraulic fracturing for stimulating natural gas production from thick, deep sandstone reservoirs having extremely low permeability.

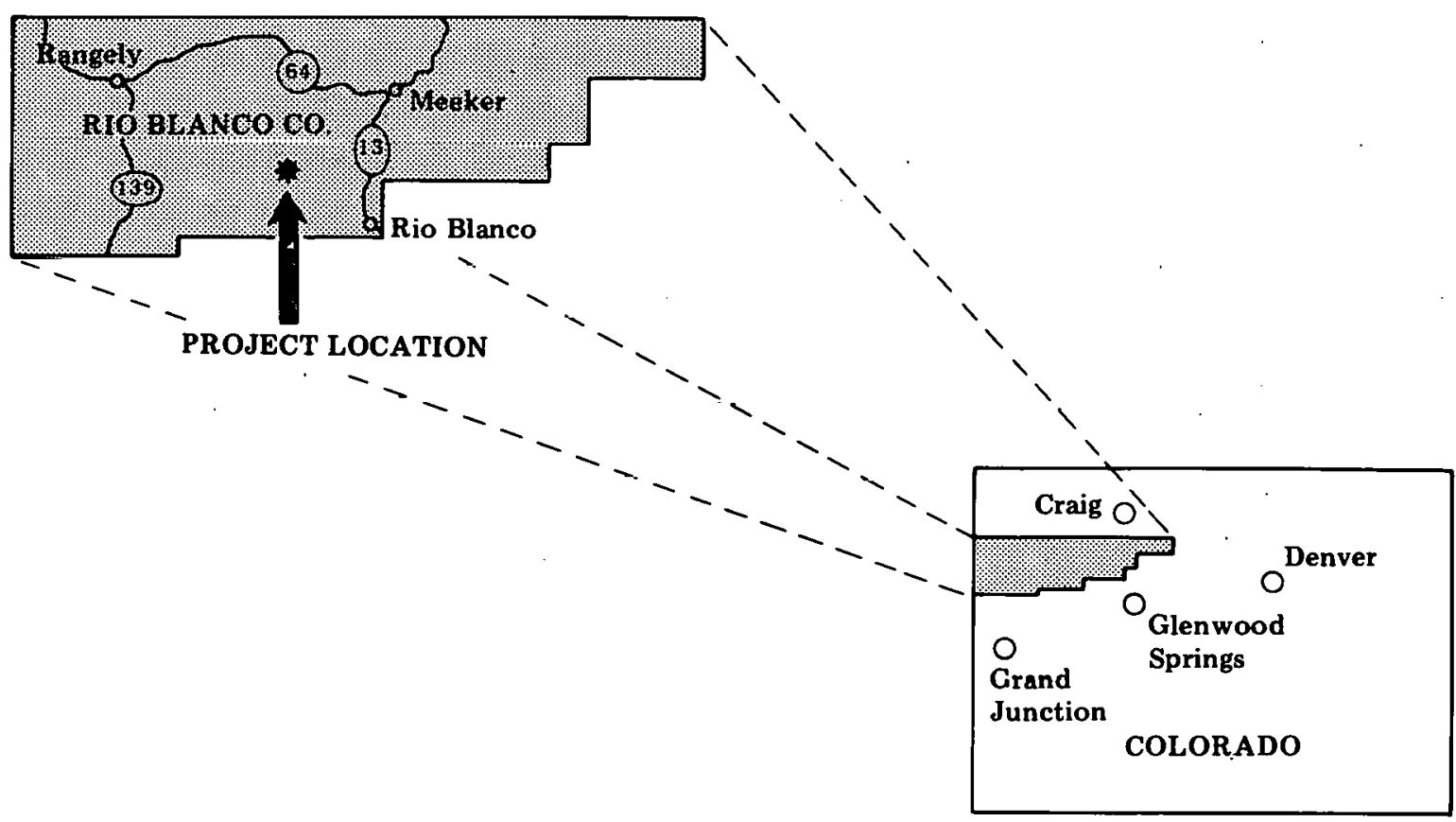




\subsection{RIO BLANCO NATURAL GAS COMPANY}

\subsubsection{Summary of Past Activities}

DOE Contract EY-76-C-08-0677 was signed with Rio Blanco Natural Gas Company in June 1976. The first MHF treatment was performed on October 22, 1976. A supplemental agreement, effective October 1,1977 , provided for a second MHF treatment, which was performed on November 30, 1977.

\subsubsection{Current Status}

Gas flow continued to be restricted due to persistant cyclical water production. The present production rate is 200 MCFD plus water with the well being flowed for further clean up. 


\section{NEVADA TEST SITE \\ NYE COUNTY, NEVADA \\ MINEBACK TESTING}

Sandia Laboratories

Status: Active

Albuquerque, New Mexico

Principal Investigator:

D. A. Northrop

\section{OBJECTIVE}

To develop an understanding of the fracturing process for stimulation and thereby improve the production of natural gas from low-permeability reservoirs. This will be accomplished by conducting controlled fracture experiments which are accessible by mineback for direct observation and evaluation.

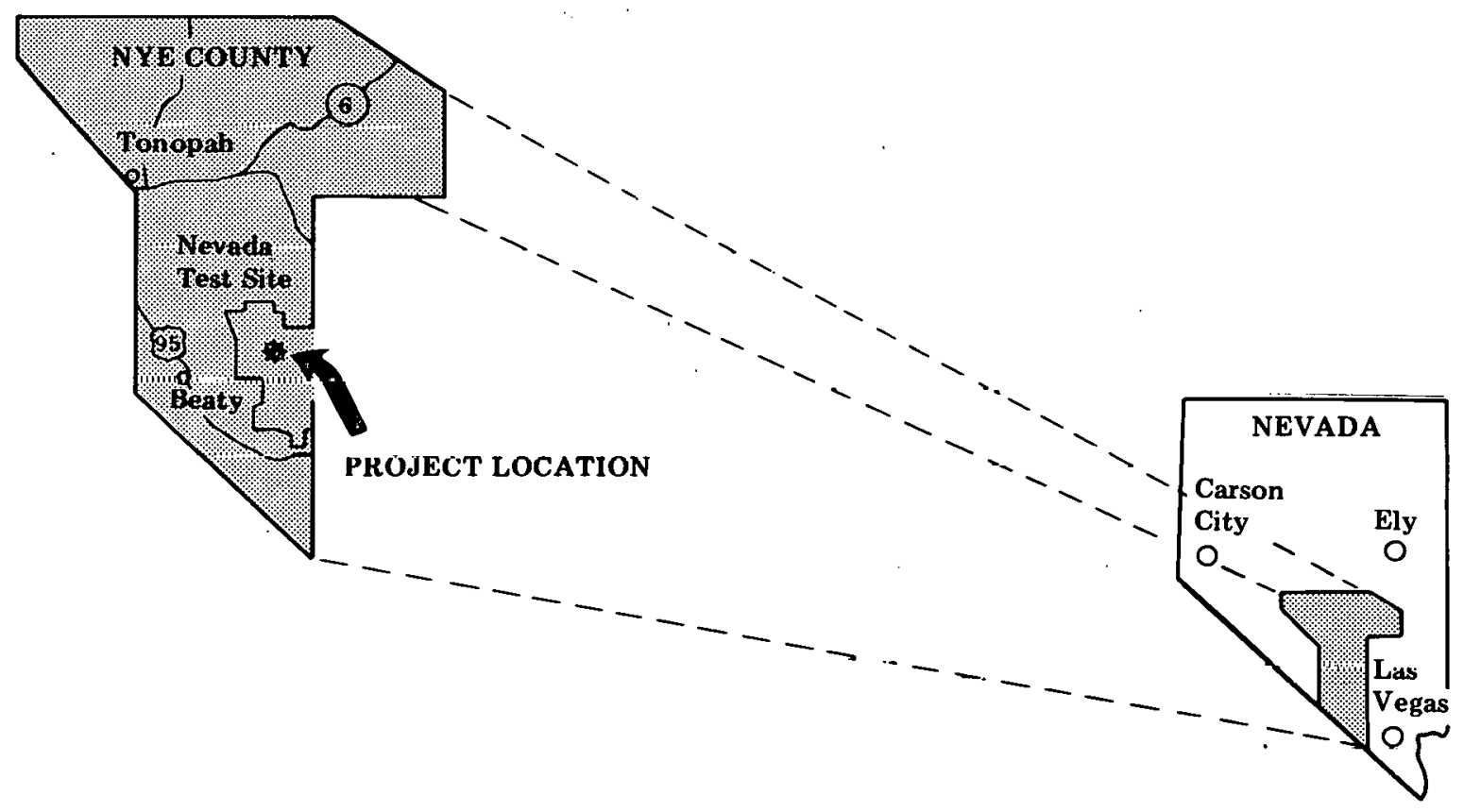




\subsection{SANDIA LABORATORIES-MINEBACK}

\subsubsection{Summary of Past Activities}

The primary activity in September was the continued evaluation of the Hole No. 6 Formation Interface Fracture Experiment; the problem of hydraulic fracture containment by mineback analysis of two grout-filled fractures propagated above and below a geologic interface of hard welded volcanic tuff overlaying a soft bedded ashfall tuff. The lower zone (ashfall tuff) was treated with $5,000 \mathrm{gal}$ of green grout, followed by 4,000 gal of black grout, and the upper fracture (welded tuff) was propagated with 5,000 gal of blue grout.

\subsubsection{Current Status}

Efforts continued throughout October to delineate the Hole No. 6 Formation Interface Experiment fractures. This experiment was designed to examine the containment of a hydraulic fracture at a geologic interface by propagating fractures above and below an ashfall tuff-welded tuff (upper formation) interface and mining back the fractures for direct observation and testing of material properties and in situ stresses. The entire length of the fractures at the interface were mined back and it was found that the lower fracture, which was initiated in the ashfall tuff, broke through the interface everywhere it contacted it even though the modulus of the welded tuff is an order of magnitude greater than the modulus of the ashfall tuff.

After the mineback of the interface was completed, and exploratory coring program was begun to determine the extent of the fractures. Ten holes were previously cored; during October, two additional holes were cored downward to locate the lower edge of the fracture. Grout was found in hole EV6 No. 11 at approximately $70 \mathrm{ft}$ below the interface and it was somewhat stranded; the thickest strand was 5-6 mm thick. In EV6 No. 12, grout was found about $100 \mathrm{ft}$ below the interface. Here, however, the fracture was about $2 \mathrm{~mm}$ thick and a number of hairline strands were in evidence. These depths, along with previous coring results, indicate a total fracture height of at least $140 \mathrm{ft}$, a value which is close to the $150 \mathrm{ft}$ fracture length observed at the interface. Further coring will be undertaken to determine the upper extremeties of the fractures and the shape of the fractures about the wellbore.

Analysis of the problem of a pressurized crack approaching a smeared interface is being addressed from three directions-closed-form analysis, computer code calculations, and experimental studies. The closed-form analysis of this continuum mechanics problem is being handled primarily on contract to Tom Cook at the Southwest Research Institute. The basic approach taken is to use transform techniques to derive appropriate integral equations which are solved numerically. This approach is similar to that used previously by Cook for the problem of a crack approaching a distinct interface. This month, the problem setup was formulated,integral equations derived in transform space and "solved" by means of residues. In the solution process, however, several governing equations were not completely satisfied. A solution is near but its validity needs to be confirmed. 
Code calculations on this problem were begun initially using the CHILES code. While this code is excellent for crack problems using enriched elements near the crack tip, problems arose in applying pressure loading to the crack surfaces near the tip. A modified code, similar to the CHILES code called APES is now running on the Sandia computers. This code also uses enriched elements but has additional features such as extra nodal points and the capability for pressure loading the crack tip. Initial check out work is complete and a few simple calculations have been made on the problem of a crack approaching an interface.

Experimental studies have only progressed as far as discussions with rock mechanics personnel. The receipt of a university proposal which deals with fracture behavior of concrete specimens made in such a way as to result in a varying Young's modulus through the specimen will model the smeared interface.

Sandia Laboratories hosted a Gas Stimulation Workshop on October 11 and 12, 1978, in Albuquerque, NM. The objective of the meeting was to allow detailed examination and discussion of the results from recent mineback experiments conducted at the Nevada Test Site. Discussion centered on three topics: (1) Hole No. 5 proppant distribution experiment, (2) Hole No. 6 formation interface experiment, and (3) a proposed fracture conductivityproppant distribution experiment. Attendees included A. B. Waters and A. Daneshy (Halliburton), M. Feves and J. Elbel (Dowell), P. Randolph (IGT), R. Saucier (Shell), R. Veatch (Amoco), Z. Shuck (WVU/METC), G. Fingleton (SAI), M. Hanson (LLL), R. Mann (CER), H. Wahl (Conoco), and eight of Sandia's personnel. Specific guidance was received on further evaluation of the Hole 5 and 6 experiments and these ideas will be incorporated into project plans. The objectives of the proposed experiment were approved. The workshop was well received and an informal advisory group was initiated, which will act at similar meetings in the future.

\subsubsection{Schedule Status}

Figure 5-19 is a milestone chart depicting the schedule for activities within Sandia's Mineback program. 

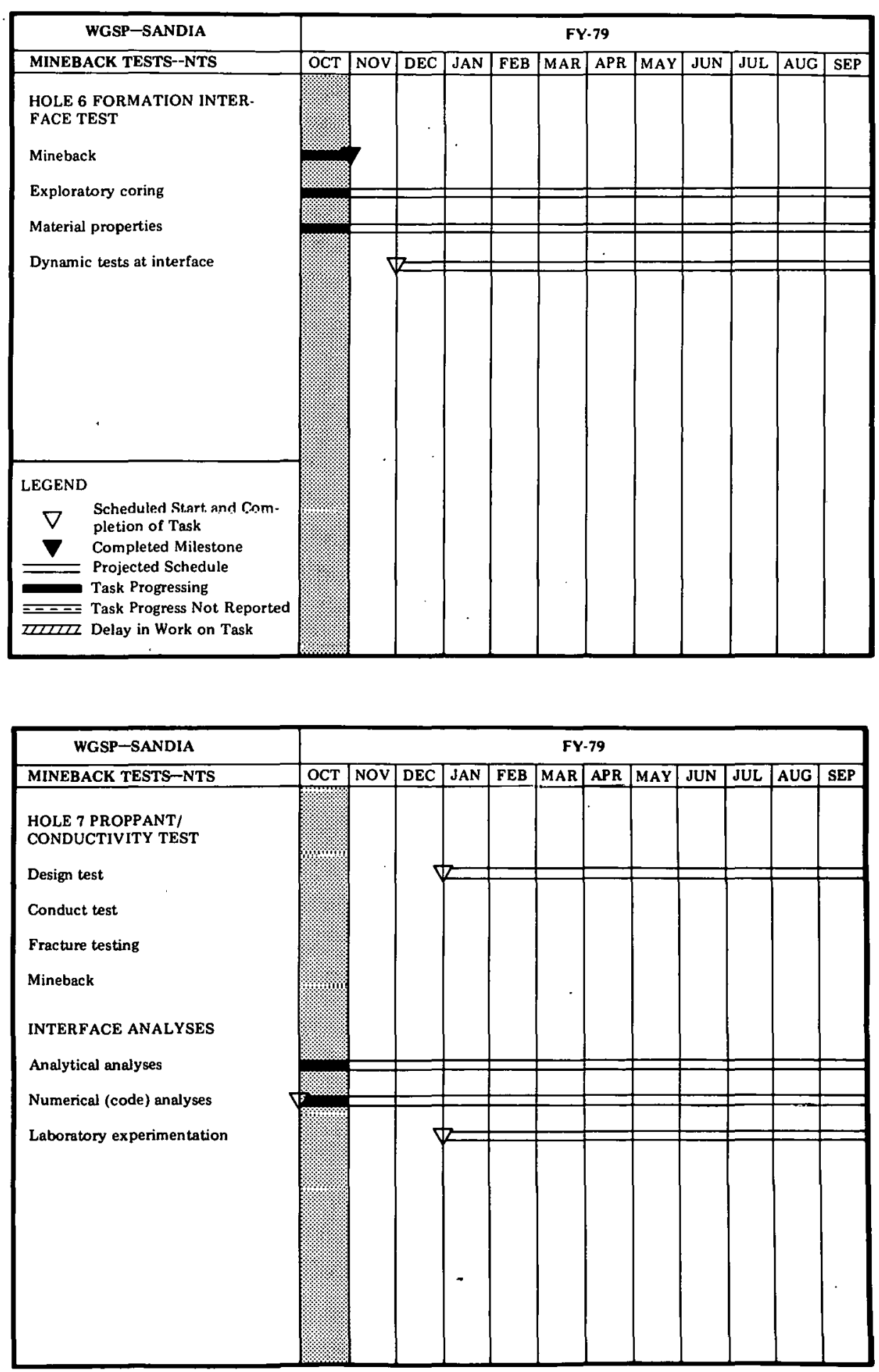

Figure 5-19 Milestone Chart-Sandia (Mineback) 